\title{
Approaches in Animal Proteins and Natural Polysaccharides Application for Food Packaging: Edible Film Production and Quality Estimation
}

\author{
Andrey Lisitsyn ${ }^{1}$, Anastasia Semenova ${ }^{1}$, Viktoria Nasonova ${ }^{1}$, Ekaterina Polishchuk ${ }^{2}$ (D, Natalia Revutskaya ${ }^{1}$, \\ Ivan Kozyrev ${ }^{1}$ and Elena Kotenkova ${ }^{2, *(D)}$ \\ 1 Department of Scientific, Applied and Technological Developments, V. M. Gorbatov Federal Research Center \\ for Food Systems of RAS, Talalikhina st., 26, 109316 Moscow, Russia; a.b.lisitsin@yandex.ru (A.L.); \\ a.semenova@fncps.ru (A.S.); v.nasonova@fncps.ru (V.N.); n.revuckaya@fncps.ru (N.R.); \\ iv.kozirev@fncps.ru (I.K.) \\ 2 Experimental Clinic and Research Laboratory for Bioactive Substances of Animal Origin, V. M. Gorbatov \\ Federal Research Center for Food Systems of RAS, Talalikhina st., 26, 109316 Moscow, Russia; \\ kat.1997@mail.ru \\ * Correspondence: lazovlena92@yandex.ru; Tel.: +7-9031684478
}

check for updates

Citation: Lisitsyn, A.; Semenova, A.; Nasonova, V.; Polishchuk, E.; Revutskaya, N.; Kozyrev, I.; Kotenkova, E. Approaches in Animal Proteins and Natural Polysaccharides Application for Food Packaging: Edible Film Production and Quality Estimation. Polymers 2021, 13, 1592. https://doi.org/10.3390/polym 13101592

Academic Editors: Farayde

Matta Fakhouri and José

Ignacio Velasco

Received: 20 April 2021

Accepted: 13 May 2021

Published: 15 May 2021

Publisher's Note: MDPI stays neutral with regard to jurisdictional claims in published maps and institutional affiliations.

Copyright: (c) 2021 by the authors. Licensee MDPI, Basel, Switzerland. This article is an open access article distributed under the terms and conditions of the Creative Commons Attribution (CC BY) license (https:// creativecommons.org/licenses/by/ $4.0 /)$

\begin{abstract}
Natural biopolymers are an interesting resource for edible films production, as they are environmentally friendly packaging materials. The possibilities of the application of main animal proteins and natural polysaccharides are considered in the review, including the sources, structure, and limitations of usage. The main ways for overcoming the limitations caused by the physicochemical properties of biopolymers are also discussed, including composites approaches, plasticizers, and the addition of crosslinking agents. Approaches for the production of biopolymer-based films and coatings are classified according to wet and dried processes and considered depending on biopolymer types. The methods for mechanical, physico-chemical, hydration, and uniformity estimation of edible films are reviewed.
\end{abstract}

Keywords: biopolymers; edible films and coatings; dry and wet processes; mechanical properties; permeability; microstructure crosslinking

\section{Introduction}

Inferior packaging or its absence causes significant food loss (about 20-25\%) due to microbiological contamination and oxidative processes, which lead to a decrease in the quality of food products and makes them unsuitable for consumption [1].

The development and application of bioactive packaging systems is a relevant field of research. The application of such smart packaging systems is a tool for protecting food from spoilage and reducing the risk of growth of pathogenic microorganisms due to both the creation of a barrier and the action of active components at the border of the product with the packaging [2,3]. The currently used packaging materials are mainly produced from petrochemical products [4,5]. The global problem of environmental pollution makes alternative environmentally friendly and biodegradable polymers be in demand [6].

Every year, the problem of recycling polymer packaging materials becomes more acute [7] due to its accumulation in large quantities, which cause significant harm to the environment [8]. The incineration or pyrolysis of polymer waste, to some extent, solves the problem of their accumulation in landfills, but does not contribute to improving the overall environmental situation [9]. Recycling of polymer waste is more environmentally friendly, but in this case, significant labor and energy costs are required for sorting polymer materials and their subsequent processing $[10,11]$. It should be noted that the recycling of polymers is carried out a limited number of times, after which the problem of burial or incineration of these materials arises again [12]. 
Concerning environmental suitability, biopolymers are environmentally friendly packaging materials $[13,14]$. The main advantage of their use as bioplastics is the closed natural cycle, where the end of one cycle leads to the beginning of the next cycle [6].

Biopolymers can be divided into three main categories depending on the origin and method of production (Figure 1): directly extracted from biomass, synthesized bio-derived monomers, and produced by microorganisms [15]. Polysaccharides and proteins are the most promising biopolymers for the production of packaging materials $[16,17]$. Proteins are heteropolymers consisting of $\alpha$-amino acids as monomeric units. The combinations of 20 amino acids to form a protein sequence allow for an almost unlimited number of various polymer chains with different physical and chemical properties. Proteins also contain a large number of functional groups that can be changed enzymatically, chemically, or physically for varying the properties of the films [16]. Polysaccharides are good candidates for replacing oil-based polymers due to their ability to form a film, affinity for paper-based materials, an appropriate barrier to gases and aromas, and good mechanical strength. Moreover, these biopolymers are biodegradable, non-toxic, and are used as a matrix for the inclusion of additives with specific functionality, such as active antimicrobial properties, for example [17].

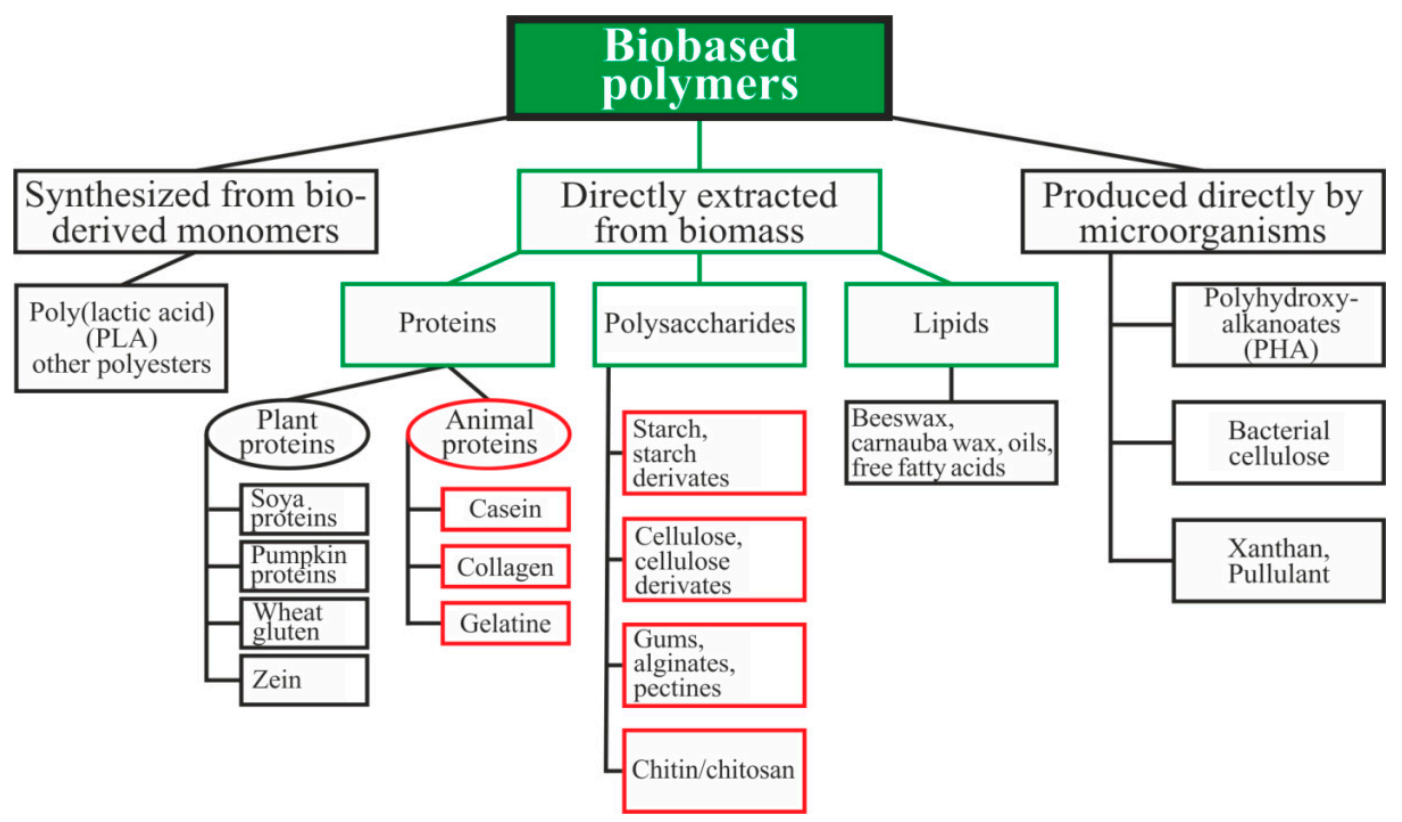

Figure 1. Schematic classification of biopolymer types $[15,18,19]$. Reproduced with permission from Popović, S.Z. et al., Biopolymers for Food Design; published by Elsevier Inc., 2018.

The prefix "bio" indicates that biopolymers are biodegradable. The word "biodegradable" means that materials can be decomposed by bacteria, fungi, and yeast to the final products of biomass under anaerobic conditions-hydrocarbons and methane [20]. These types of polymers consist of monomers that are covalently connected, forming a chain of the molecule. They are also produced inside the cell as a result of complex metabolic processes. Biopolymers can be used for food packaging as a replacement for oil-based plastics made from petroleum due to their biodegradability, renewability, and wide distribution [21].

Environmental friendliness is a key ideology nowadays. The use of biopolymers from renewable resources could solve global plastic pollution. For many years, researchers have been trying to develop and design packaging materials based on natural biopolymers. However, animal proteins and natural polysaccharides are characterized by some undesirable properties caused by their chemical nature and structure. These disadvantages reduce their competitiveness with oil-based plastics but can be overcome. In this review, we summarize the description of such popular biopolymers as starch, cellulose, pectin, 
chitosan, alginate, casein, collagen and gelatin, considered for films and coatings production in general and for each biopolymer. The main characteristics of packaging materials based on animal proteins and natural polysaccharides, appropriateness for certain type of product based on properties of polymer, as well as ways to improve it are also described.

\section{Biopolymers Used for Food Packaging}

Biopolymers are widely implemented and can be used as coatings and films [4,22]. Coating involves the formation of a cover directly on the surface of food products, whereas films are structures that are used separately after formation [23].

Materials based on biopolymers must meet the basic requirements of health safety, mechanical and chemical resistance, and durability [24,25]. Therefore, food packaging should not only be biodegradable, but also functional. Compared to synthetic polymers derived from petroleum, biopolymers have a more complex chemical structure and side chain structure, which provides additional opportunities for the formation of packaging materials with specific characteristics for specific purposes $[18,20]$.

Biopolymers directly extracted from biomass as polysaccharides and animal proteins, which are most often used for the preparation of packaging materials for food products, will be considered in this review $[16,26,27]$.

\subsection{Starch}

Starch is one of the most readily available polysaccharides on the planet [28]. The plants from which it is obtained grow in almost all temperate climate zones. Corn, wheat, potatoes, and rice are the world leaders: $84 \%, 7 \%, 4 \%$, and $1 \%$, respectively [29]. This biopolymer is a mixture of amylose and amylopectin (Figure 2), the ratio of which varies depending on the type of starch.
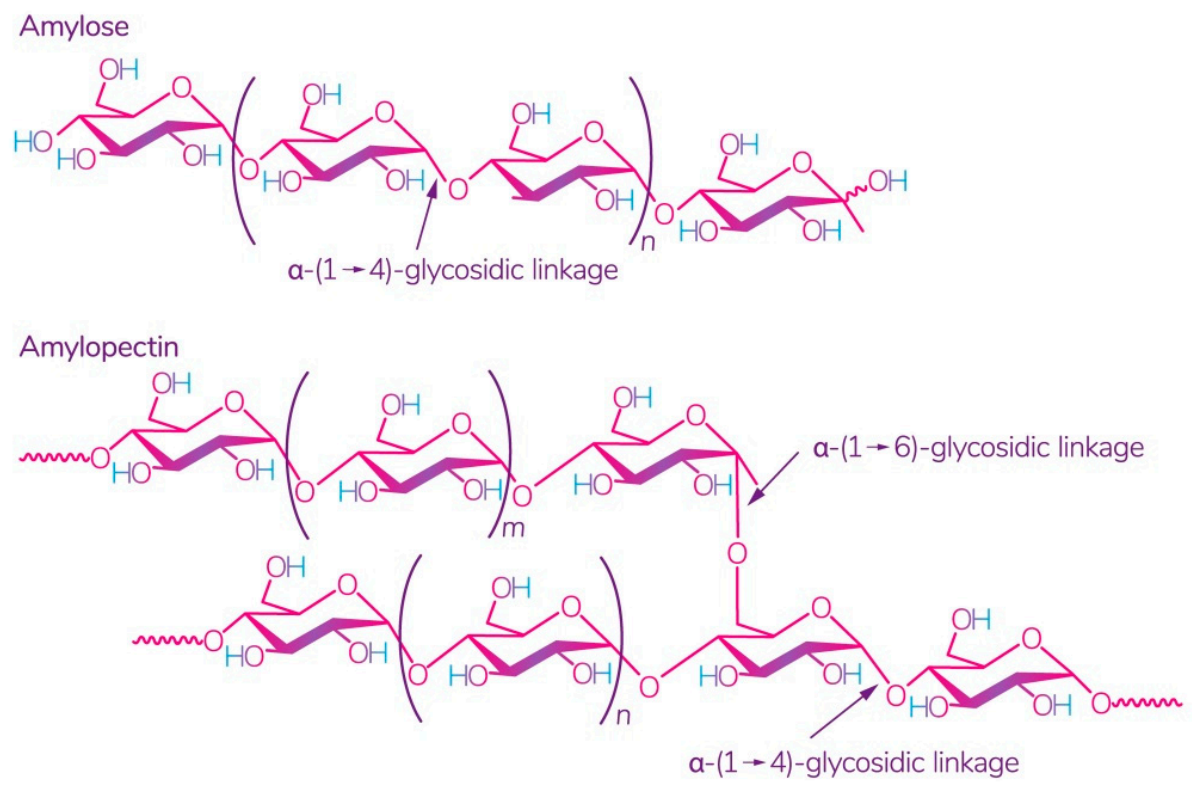

Figure 2. Structure of amylose and amylopectin [30]. Reproduced from Kadokawa, Polymers; published by MDPI, Basel, Switzerland, 2012.

The ratio of amylose:amylopectin varies significantly not only between different plants, but also within a single plant species or plant organ [31]. The conditions and phase of growth also influence this ratio $[32,33]$. Several studies have shown that a change in this ratio implies a change in the physical and chemical characteristics of starch and its interaction with other molecules, which leads to different swelling capacity [34], solubility in water, microscopic properties [35], and stability and barrier/mechanical properties in starch films [36]. According to some studies, starch with a high content of amylose, for 
example, from peas, has the best mechanical and gas barrier properties [37]. It was also noted that lentil starch ( $30 \%$ amylose) has a strong tendency to gelatinize at a relatively low concentration compared to corn and potato starch [29].

Cereal (grain) starch is obtained by its physical separation from non-starch components. Various processes of wet grinding of grains have been developed for the production of starch. The main stages of these processes are soaking, grinding, and separation of grain components [38]. Potato starch is extracted from potato tubers in a process called bio-processing: the potatoes are ground, and the contents of the cells are released, including starch and protein [39].

Starch-based polymers have low moisture resistance, which limits their use in packaging. The usual form of natural starch is a crystalline molecular structure that is not flexible [40]. However, an interesting starch derivative is thermoplastic starch (TPS), which is more convenient for films production [41,42], which could be obtained with thermal and physical impacts in the presence of plasticizers [40]. Various physical and chemical reactions are involved in the heat treatment of starch-based polymers, such as water diffusion, granule expansion, gelatinization, melting, crystallization, and extrusion [43].

TPS with improving properties can be used in the field of food packaging since it is economical and available in large quantities. The production of flexible and solid packaging (biofilms, bags, laminated plastic, etc.) is the main sector of TPS application in the food industry [40]. Polymer films derived from starch are biodegradable and have good properties as oxygen barriers. However, the amount of plasticizer, humidity, and amylose content are the limiting factors that determine the mechanical properties of TPS. The type and amount of plasticizer used in the production of thermoplastic starch strongly affect the physical, chemical, and thermal properties of the film [44]. Various structural enhancers, such as microcrystalline cellulose, carboxymethylcellulose, carbon nanotubes, etc., are added to the starch-polymer matrix in order to improve its properties [45]. Various types of such reinforced starch are already successfully used in the packaging of bread, vegetables, and meat products stored in standard conditions [41,46,47].

\subsection{Cellulose}

Cellulose is the most common natural biopolymer and consists of $\beta$-(1-4)-D-glucopyranose monomers (Figure 3) [48]. It is biosynthesized by a number of living organisms, from lower to higher plants, marine animals, bacteria, and fungi [49]. It has been estimated that 1011-1012 tons are synthesized annually by photosynthesis in a fairly pure form, for example, in the seed hairs of the cotton plant, but mainly cellulose combines with lignin and other polysaccharides (hemicelluloses) in the cell wall of woody plants [50]. Although cellulose is primarily found in forests, where wood is the most important source, cellulose-containing materials include agricultural residues, aquatic plants, grasses, and other plant matter [51,52]. Commercial cellulose production is based on harvested sources, such as wood, or on natural sources with high biopolymer content, such as cotton [53]. In contrast with starch, cellulose is a linear polymer without winding and branching [48]. Numerous hydroxyl groups in cellulose form strong hydrogen bonds, which make the material non-fusible. Chemical modification of cellulose is required for the production of flexible materials, which often involves the replacement of hydroxyl groups with acetate or methyl groups (esterification), the purpose of which is to reduce the intensity of the hydrogen bonds [54]. The rate of esterification and type of replacers, as well as the length of the polymer chain, affect the further permeability, mechanical properties, and solubility. Methylcellulose $(\mathrm{MC})$ and carboxymethylcellulose (CMC) are the most common cellulose esters and have good film-forming properties, which allow them to be used as packaging materials for food products [55-58]. 


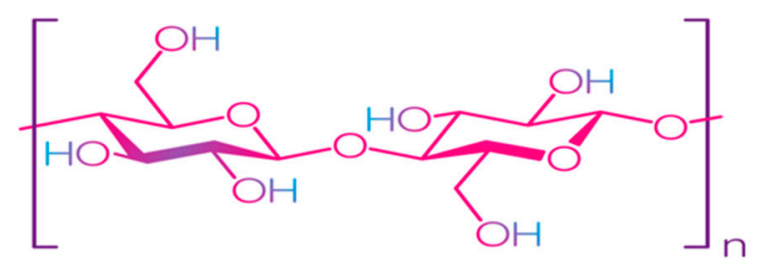

Figure 3. Structure of cellulose [49]. Reproduced with permission from Trache, D. et al., International Journal of Biological Macromolecules; published by Elsevier Ltd., 2016.

Methylcellulose (MC) is formed when one or more hydroxyl groups (-OH) in the anhydroglucose are replaced by a methoxide group $\left(-\mathrm{OCH}_{3}\right)$. The degree of substitution of MC ranges from 1.4 to 2.0, and it is soluble in cold water [59]. It is reported that MC forms unbreakable, flexible, transparent, tasteless, and non-toxic films that have good barrier properties for oxygen, but bad ones for water vapor [60]. MC has a relatively high tensile strength and elastic modulus, so it demonstrates a reinforcing effect [61] and exhibits improved mechanical properties in mixtures containing proteins, lipids, etc. [62].

Carboxymethylcellulose (CMC) is a cellulose derivative in which some hydroxyl groups of glucopyranose units in cellulose are replaced by carboxymethyl groups. CMC is formed by reaction with chloroacetic acid $\left(\mathrm{ClCH}_{2} \mathrm{CO}_{2} \mathrm{H}\right)$ and catalyzed by alkali [63]. The amount of carboxymethyl groups in the cellulose molecule improves the strength of CMC film due to strong intermolecular forces [64]. Initially, CMC was studied as a hydrogel polymer, but it was later discovered that its dry form could be considered a biodegradable alternative to petroleum-based food packaging materials [64]. CMC easily absorbs moisture, dissolves in cold water, and exhibits thermal gelatinization [65]. CMCbased films can be combined with MC, clay, chitosan, etc., which usually improves the mechanical properties of the film: the tensile strength and elastic modulus increase, while the strain at break of the films is reduced [65]. It was noted that such a plasticizer as glycerin significantly increases the flexibility of the film, but also reduces the tensile strength and elastic modulus [66].

Cellulose derivatives are more suitable for packaging that is in direct contact with food products [65]. Studies of the properties of various cellulose derivatives used for film formation are continuing with the aim of developing mixtures of cellulose derivatives with other biopolymers to improve the mechanical, barrier properties and increase the shelf life of packaged food products $[46,67,68]$.

\subsection{Pectin}

Pectin is one of the main components of the plant cell wall, contributing to the integrity and rigidity of tissues, and is considered one of the most complex macromolecules in nature [69]. Although pectin is ubiquitous in the plant kingdom, pectin derived from apples, citrus fruits, sunflowers, and sugar beets is an undisputed commercial source for the processing industry due to their physical and chemical properties and the availability of biomass [70]. Pectin is a poly- $\alpha-1-4$-galacturonic acid (Figure 4a) with different degrees of methylation of carboxylic acid residues and/or amidated polygalacturonic acids (Figure 4b) [71]. Carboxyl groups of galacturonic acid are esterificated with methanol, resulting in methoxylated carboxyl groups. On the other hand, amidated carboxyl groups are obtained when galacturonic acid is converted with ammonia to carboxylic acid amide. 


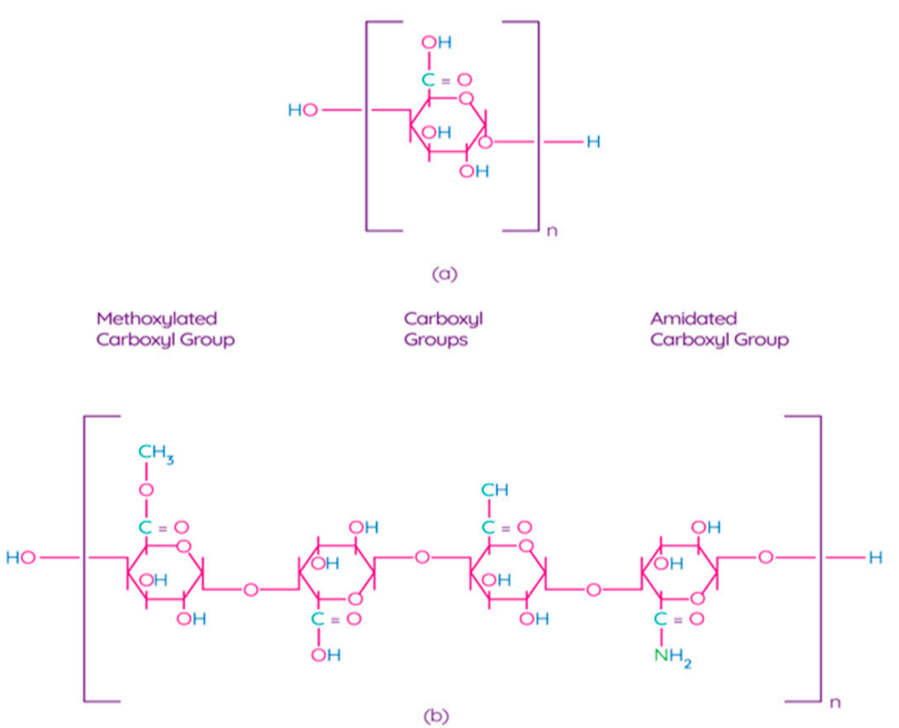

Figure 4. Chemical structure of polygalacturonic acid (a) and representative chemical structure of pectin, showing typical repeating groups (b) [72]. Reproduced with permission from Espitia, P.J.P. et al., Food Hydrocolloids; published by Elsevier Ltd., 2013.

According to the degree of esterification by methanol (the ratio of esterified galacturonic acid groups to its total number), pectin can be classified as high-methoxylpectin (HMP, $>50 \%$ of esterified carboxyl groups) pectin or low-methoxyl pectin (LMP, $<50 \%$ of esterified carboxyl groups) [70]. The degree of esterification affects the gelling properties of pectins. For example, pectin with a low content of methoxyl groups forms a gel in the presence of multivalent ions, which bonds pairs of carboxyl groups of different pectin chains. Pectin with a high content of methoxyl groups forms a gel in acidic solutions with the addition of various sugars, such as sucrose or glucose [72,73]. LMP is used for encapsulation, food packaging film processing, and low-calorie gels in dietary foods [72]. Structurally, pectins are classified as rhamnogalacturonan-I (RG-I; "hairy" pectin), substituted galacturonans (RG-II or SG; "hairy" pectin), and homogalacturonans (HG; smooth pectin). The hairy region of pectins (RG-I and RG-II) has a high probiotic potential [74]. Thus, based on the macromolecular and microstructural characteristics of pectins, the scope of their application in food products is determined.

Pectin is an ingredient used in the food industry without any restrictions other than current good manufacturing practices, is generally recognized as safe (GRAS) by the U.S. Food and Drug Administration (FDA), and is used in food primarily as a gelling agent, stabilizing agent, or thickener in products such as jams, yogurt drinks, fruit milk drinks, and ice cream $[75,76]$. The ubiquitous presence, low cost, structural flexibility, and polymerization ability of pectin contribute to its use as a matrix for active food packaging materials [70]. Since bioactive packaging films made from pectin have very weak antimicrobial properties, their antimicrobial potential can be enhanced by integrating and combining them with various functional compounds, such as essential oils, phenolic compounds, nanomaterials, free fatty acids, and others [77]. The production of edible films from pectin can be carried out in various ways, such as casting, extrusion, spraying, and coating with a knife [78].

\subsection{Chitosan}

Chitosan is a linear polysaccharide consisting of randomly linked units of $\beta-(1,4)-\mathrm{D}$ glucosamine and N-acetyl-D-glucosamine (Figure 5). Chitin is the second most common structural polysaccharide found in nature after cellulose and is usually deacetylated by an alkali for chitosan production [79,80]. Natively, chitin is presented in the form of ordered crystalline microfibrils that form structural components in the exoskeleton of arthropods or in the cell walls of fungi and yeast. So far, the main commercial sources of chitin are 
the shells of crabs and shrimps [81]. In industrial processing, chitin is extracted by acid treatment to dissolve calcium carbonate, and then by an alkaline solution to dissolve proteins. In addition, a discoloration stage is often added to remove the pigments and obtain a colorless pure chitin [82]. Chitin is usually isolated from the exoskeleton of crustaceans and, in particular, from shrimps and crabs, where $\alpha$-chitin is produced [83]. Squid is another important source of chitin, in which it exists in the $\beta$-form, which has been found to be more amenable to deacetylation. Such chitin also shows higher solubility, reactivity, and affinity for solvents and swelling than $\alpha$-chitin due to the much weaker intermolecular hydrogen bond attributed to the parallel arrangement of the main chains [83]. Some types of insects, fungi, bacteria, and algae can also be alternative sources of chitin/chitosan [84-86].
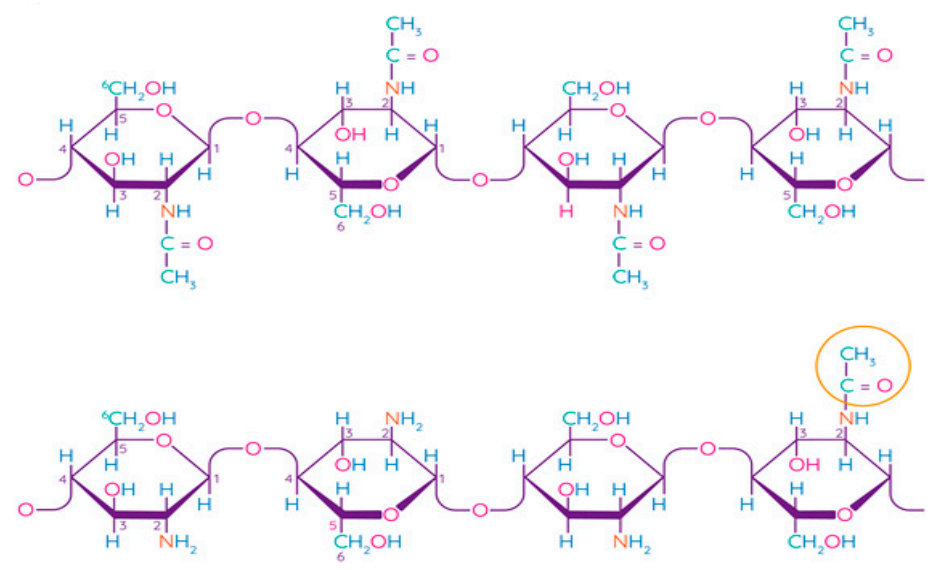

Figure 5. Chemical structure of chitin and chitosan [87]. Reproduced with permission from Rasul, R.M. et al., Carbohydrate Polymers; published by Elsevier Ltd., 2020.

The term "chitosan" usually refers to a family of polymers produced after the deacetylation of chitin to varying degrees [81]. In fact, the acetylation degree, which reflects the balance between the two types of residues, distinguishes chitin from chitosan. When the acetylation degree is higher $60 \%$, the product is called chitosan and becomes soluble in acidic aqueous solutions [88]. A depolymerization reaction also occurs during deacetylation, as evidenced by changes in the molecular weight of chitosan. Chitin can be converted into chitosan by enzyme treatment [89] or by a chemical process [90]. Chemical methods are widely used for commercial purposes of producing chitosan due to their low cost and suitability for mass production [81]. Chitosan has been found to be non-toxic, biodegradable, bio-functional, and demonstrates good film-forming qualities and antimicrobial properties [91].

However, films prepared only from chitosan do not meet the criteria for packaging materials. They are rigid and brittle; therefore, it is important to use plasticizers to improve their mechanical properties. Various plasticizers have an effect on the stability of plasticized films. It was found that polyethylene glycol (PEG) and glycerin are the best candidates as plasticizers of chitosan films [92]. It was found that other small-molecular organic materials also improve the mechanical properties of chitosan films, but their effectiveness decreases within a few weeks [92]. The addition of PEG and glycerol promotes the formation of relatively flexible and stable (at least for several months) chitosan films. In general, these substances prevent the formation of double bonds between adjacent polymer chains, which prevents recrystallization [93]. Plasticizers modify the mechanical properties of chitosan without changing its fundamental chemical structure [92].

In comparison with other biopolymers used for food packaging, chitosan has an advantage due to its ability to include such functional substances as minerals or vitamins and its antibacterial activity, which is important for maintaining the quality of products [94-96]. 


\subsection{Alginate}

Alginates are natural indigestible polysaccharides, usually produced and purified from various genera of brown algae (mainly Laminaria hyperborean, Macrocystis pyrifera, Ascophyllum nodosum, and to a lesser extent, Laminaria digitate, Laminaria japonica, Eclonia maxima, Lesonia negrescens, Sargassum sp.) [97]. Some bacteria, such as Azotobacter vinelandii or mucoid strains of Pseudomonas aeruginosa, also synthesize alginate-like polymers as exopolysaccharides [98,99]. Azotobacter vinelandii is a strict aerobe that can fix nitrogen and synthesize two polymers during vegetative growth: alginate and intracellular polyesters (polyhydroxybutyrate) [100]. A. vinelandii produce alginate during the encystment process as a mechanism for increasing resistance to drying in adverse environmental conditions to maintain cell hydration, being its structural element [101]. Moreover, it can act as a protective barrier against heavy metal toxicity, creating an ion exchange system with selectivity for $\mathrm{Ca}^{2+}$ [102]. P. aeruginosa (mucoid phenotype) produce alginate as the causative agent of cystic fibrosis, and it is associated with pathogenicity. Alginate biosynthesis in Pseudomonas $s p p$. is induced under dehydration conditions and is probably a key component of stable biofilms in various media [103].

The molecular structure of alginates consists of unbranched linear binary copolymers of $\beta$-D-mannuronic acid $(\mathrm{M})$ and $\alpha$-L-guluronic acid $(\mathrm{G})$ residues bound by $1-4$ glycosidic bonds (Figure 6) [97]. The structure of alginate algae can be divided into three fractions (three blocks of uronic acid): these are the homopolymer regions of the M and G blocks and the alternating MG blocks containing both polyuronic acids [104]. Bacterial alginates have O-acetyl groups, while in the structure of alginate algae, they are absent [105]. In addition, bacterial alginates have a higher molecular weight compared to algae polymers [106]. The source of alginate affects the ratio of $\mathrm{M}$ and $\mathrm{G}$ residues, which has an impact on the physical and chemical properties of alginate, as well as on solution viscosity and thickness of the film [97].

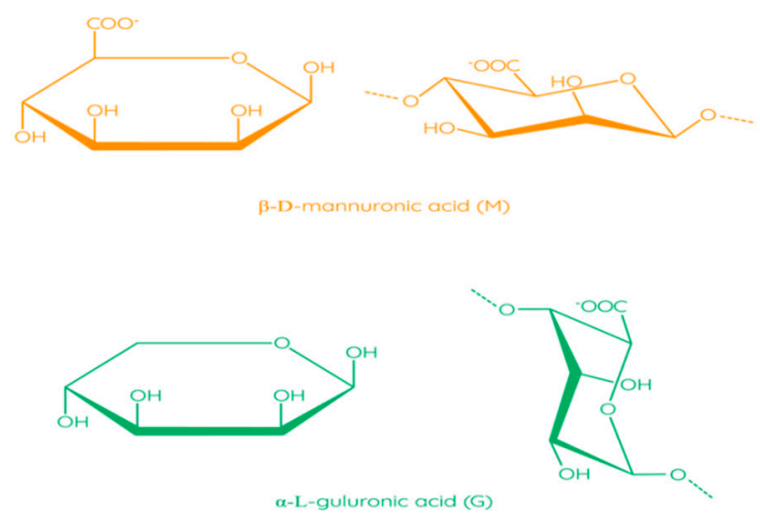

Figure 6. Structural formulas of monomers in alginate [97]. Reproduced from Parreidt, T.S. et al., Foods; published by MDPI, Basel, Switzerland, 2018.

The solubility of various types of alginates in numerous solvents and solutions was indicated by Kimica Corporation [107]. The FDA classifies food grade sodium alginate as a GRAS (generally considered safe) in the Code of Federal Regulations (CFP) and list its use as an emulsifier, stabilizer, thickener, and gelling agent [108]. The European Commission (EC) has added alginic acid and its salts (E400-E404) to the list of permitted food additives [109].

Alginate is widely used in various industries, such as food, beverage, textile, printing, and pharmaceutical, as a thickener, stabilizer, emulsifier, chelating agent, encapsulator, suspending agent, or used for the formation of gels, films, and membranes [110]. About 30,000 metric tons of alginate derived from brown algae are produced annually [100]. Alginate is known for its biocompatible and biodegradable properties, as well as its low price. The ability of functional groups of $G$ blocks to interact with polyvalent cations (for example, $\mathrm{Ca}^{2+}, \mathrm{Al}^{3+}$, and $\mathrm{Fe}^{3+}$ ) is an important characteristic of alginate [111]. Among 
divalent ions, calcium ions usually react with alginate to form a polymer with low solubility. In general, the length of the G-block characterizes the ability and selectivity of the alginate in the formation of these interactions, whereas the M and MG blocks have almost no selectivity. The $\mathrm{M}$ and $\mathrm{G}$ blocks bind via ions to form a three-dimensional structure («eggbox») [112]. This triggers the process of anionic exchange, in which the water-soluble alginate exchanges its counter ions for $\mathrm{Ca}^{2+}$. This ionic crosslinking leads to the formation of cold-setting and heat-resistant films. Alginate films are cross-linked to improve their water resistance, mechanical properties, and coherence [111].

\subsection{Casein}

Caseins are suitable hydrocolloids for the formation of edible films among proteins due to their high nutritional value, solubility in water, and ability to emulsify. Casein is the main protein extracted from milk $(\sim 80 \%)$ [113], consisting of four different protein fractions: $\alpha_{S 1^{-}}, \alpha_{S_{2}-}, \beta-$, and $k$-casein [114], which together form colloidal micelles in milk (Figure 7) stabilized by casein structures and calcium-phosphate bridges [115]. The unique properties of the four protein fractions affect the film-forming ability of casein [116].
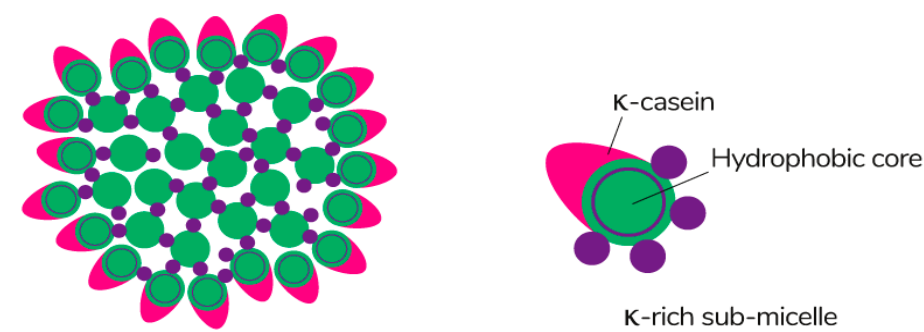

K-rich sub-micelle

K-poor

Calcium phosphate

Figure 7. The schematic of the submicelle model of the casein micelle [117]. Reproduced with permission from Horne, D.S., Current Opinion in Colloid \& Interface Science; published by Elsevier Ltd., 2005.

The global production of caseins and caseinates is difficult to determine due to the lack of significant data. The largest casein producers are New Zealand (150,000 tons), Netherlands (85,000-10,000 tons) and Germany (25,000-40,000 tons). The global market for casein or caseinates used in the food industry ranges from 200,000 to 2,500,000 tons [118].

Casein is precipitated from skimmed milk by acidifying it to produce acidic casein, or the milk is treated with rennet to produce rennet casein. The precipitated casein clot is separated from the serum, washed, and dried [119]. Caseinates are water-soluble derivatives of acidic caseins formed by reaction with alkalis. Edible casein is a dairy byproduct that is used as an ingredient in many foods, including dairy products [120]. The development of food technologies and their applications has increased the production of casein and the demand for it. Its production differs from that of non-food casein (also called industrial casein) because food casein is produced under sanitary conditions [118]. In addition, food-grade chemicals are used for its production that undergoes sufficient heat treatment to ensure that casein is safe for human consumption [118]. Intensive research on production technologies over the years and their implementation into factories has significantly improved the approaches for food-grade casein production.

Depending on the coagulation method, different types of casein with certain characteristics are obtained; rennet and acid casein are the main available types [121]. Acidic casein is insoluble in water, has a $\mathrm{pH}$ of about 4.6 , and is precipitated by acidifying milk with mineral acids or lactic acid [113]. Rennet casein is insoluble in water, has a $\mathrm{pH}$ of about 7.5, and is coagulated by the action of chymosin, which cleaves the k-casein tail and causes destabilization of the casein micelles [114]. Acidic casein can be solubilized by neutralization with alkali, such as sodium, potassium, or calcium hydroxide, to produce 
sodium, potassium, or calcium caseinates, respectively. This caseinate does not contain colloidal calcium phosphates, has a $\mathrm{pH}$ close to 7 , and is highly soluble in water [122].

Casein films have good barrier properties for oxygen and other non-polar molecules due to the distribution of polar amino acids along the protein chain, which allows them to protect products that are prone to oxidation [122]. On the other hand, the interaction forces between the polar and non-polar amino acids in the casein structure form a cohesive film matrix that tends to shrink during drying and becomes brittle [123]. Food-grade plasticizers, such as glycerin or sorbitol, are added to the film-forming solution in order to solve this problem. Plasticizers increase the thermoplasticity of the protein film but reduce its strength [124].

Although casein films have potential for use as food packaging, some disadvantages need to be addressed before they can be widely used for commercial purposes. Caseinbased films are very sensitive to moisture, they absorb and release water molecules, which greatly affect their mechanical and barrier properties, and moreover, they are mostly soluble in water, which limits their areas of application [125]. It is also worth noting that plasticized casein films cannot provide high mechanical strength or good elasticity compared with synthetic polymer materials. By crosslinking polymer chains, chemical and physical processing can be used for modification of the polymer matrix, which improves the functionality of the protein film [126]. Glutaraldehyde or the natural compound genipin, as well as transglutaminase, etc. are typical chemicals used as crosslinking agents $[114,127,128]$. In general, aldehydes are quite effective as binding agents of protein molecules, but their high toxicity is unacceptable for foods. Genipin and transglutaminase are known to be safe, but their high cost limits their further use in industry [114]. Thus, the search for new cheap crosslinking agents safe for use in the food industry is underway.

\subsection{Collagen}

Collagen is the most abundant protein in the extracellular matrix of vertebrates, accounting for approximately $30 \%$ of the total body protein mass. It is absent in plants and unicellular organism, where its role is played by polysaccharides and cellulose. Collagen is presented in the body walls and cuticle in invertebrates, while in mammals, it is found in the cornea, bones, blood vessels, cartilage, dentin of teeth, etc. [129].

Bovine hides are a by-product of meat production and mainly used for the production of leather, but the inner corium layer of the hide is rich in collagen [130]. This collagen has a higher denaturation temperature compared to collagen from marine sources [131]. Collagen can also be extracted from fish and pigs, but there are some limitations: the use of fish collagen is limited because its low hydroxyproline content [132] gives collagen a low denaturation temperature, while pork collagen is restricted due to religious considerations [133].

Collagen consists of three parallel chains of $\alpha$-helices twisted in the form of a right triple helix [129] and constructed from frequently repeated fragments with a characteristic sequence -Gly-X-Y- (Figure 8). Glycine is every third amino acid residue, proline is often found in the $\mathrm{X}$ position, and the $\mathrm{Y}$ position can be occupied by both proline and 4-hydroxyproline. In addition, the collagen molecule contains residues of 3-hydroxyproline and 5-hydroxylysine. The right triple helix self-associates to form highly ordered crosslinked fibrils [129]. These fibrils form insoluble fibers that provide an extracellular matrix with high integrity and mechanical tensile strength due to its tightly wound triple helical structure. Collagen molecules are divided into 26 different types, which are grouped into 8 families, depending on its structure, chain bonding, and position in the organism. These families include fibril-forming, basement membrane, anchoring fibrils, microfibrillar, hexagonal network-forming, transmembrane, multiplexins and fibril-associated collagens with interrupted triple helix [134]. 


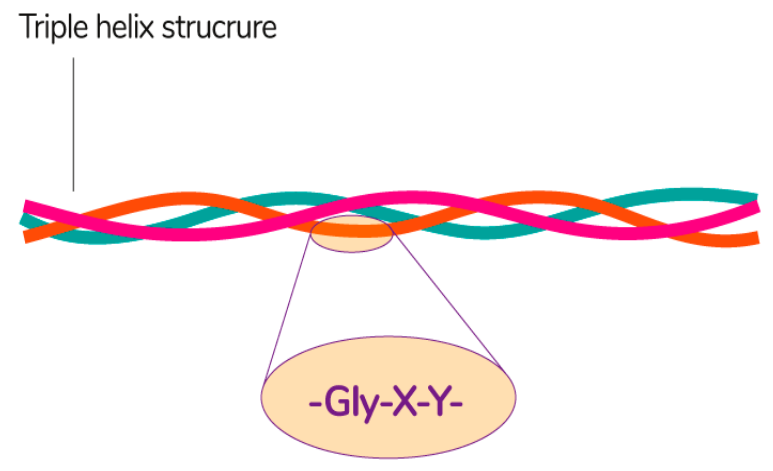

Figure 8. The general structural features of collagen [135]. Reproduced from Sebald, A., proofread/edited by Mitchell, D.A. Maxfacts; published by University of York, 2019.

Water-soluble collagen presents in a small percentage of total collagen. The solubility of collagen depends on the type of tissue and age. A neutral salt solution or dilute acetic acid are the most commonly used solvents for collagen extraction. Strong alkali or enzymes are used to extract the insoluble collagen to break down the additional cross-linked bonds [136]. Collagen can be used for the production of edible films in the meat industry, e.g., for sausages, salami, snacks [136], due to its good mechanical properties [137]. Fibrillar collagens can easily form stable films capable of contracting and stretching to adapt to the compression and expansion of meat raw materials during continuous processing $[138,139]$. Collagen films can become an embedded/edible part of meat products so they can provide safety benefits, control quality changes, and reduce the loss of shrinkage of meat and meat-based products during storage, thereby extending the shelf life and maintaining the visual appeal of products for a long time [140].

\subsection{Gelatin}

Gelatin is a naturally occurring water-soluble protein characterized by the absence of a noticeable odor and the random configuration of polypeptide chains in an aqueous solution. It is obtained by partial hydrolysis of collagen [141]; its structure is rigid rodshaped molecules that are located in fibers connected by covalent bonds [142].

Pig skin was used as a raw material for the production of gelatin in the 1930s and continues to be the most important material for the large-scale industrial production of food gelatin [143]. For more expensive applications, such as pharmaceuticals, gelatin is usually obtained from cattle bones, which is considered a more complex and expensive extraction process [144]. However, in an effort to replace pork and bovine gelatin, fish gelatin production has increased over the past decade, accounting for more than $1.5 \%$ of total gelatin production. In recent years, by-products obtained in the fishing industry, such as heads, skin, bones, fins, muscle parts, scales, internal organs, and others, are considered as potential sources of gelatin and not recyclable waste [145]. The main disadvantages of fish gelatin are its rheological properties, since it is less stable than mammalian gelatin. Moreover, since the production of gelatin from fish and poultry is still limited, the resulting products are less competitive in price than products made from mammalian gelatin [146,147].

Gelatin is a heterogeneous polypeptide mixture of $\alpha$-chains, $\beta$-chains, and $\gamma$-chains (Figure 9). 


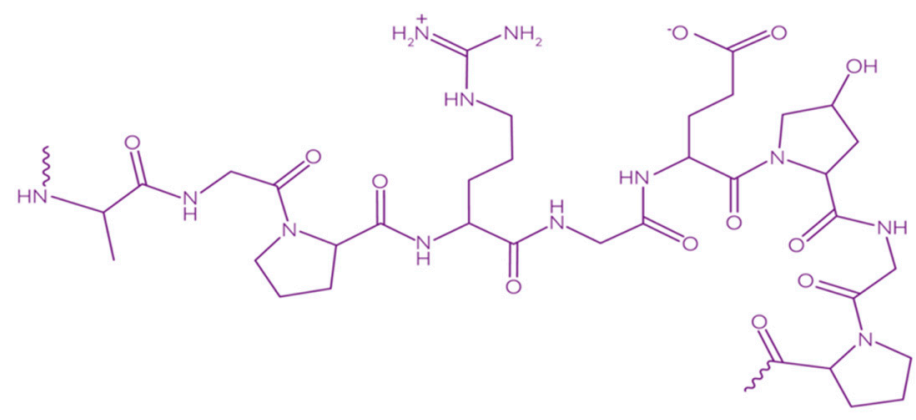

Figure 9. Chemical structure of gelatin [148]. Reproduced with permission from Kariduraganavar, M.Y., et al., Natural and Synthetic Biomedical Polymers; published by Elsevier Inc., 2014.

Gelatin can be divided into two types depending on the processing method. Type A has an isoelectric point at $\mathrm{pH} \sim 8-9$ and is obtained from acid-treated collagen. Type $\mathrm{B}$ has an isoelectric point at $\mathrm{pH} \sim 4-5$ and is obtained from an alkali-treated collagen, during which asparagine and glutamine residues are converted to their respective acids, resulting in a higher viscosity [149]. Gelatin obtained from pig skin is commonly referred to as type $\mathrm{A}$, and gelatin obtained from beef skin or cattle skins and bones is referred to as type B.

Gelatin has various functional properties that can be divided into two groups: properties related to the external surface, such as protective colloidal function, formation and stabilization of emulsion and foam, adhesion and cohesion, as well as the ability to form films and properties related to gelation, such as thickening, texturing, and water-binding ability [150-152]. Thus, a wide range of gelatin applications can be used in the food, packaging, pharmaceutical, cosmetic, and photographic industries, but the limited thermal stability and mechanical properties of gelatin, especially during processing, limit its implementation [139].

The film-forming properties of gelatin are widely used as an outer film to protect food products from drying out, exposure to light and/or oxygen during their shelf life [153]. Due to the high hygroscopicity of gelatin, it tends to swell or dissolve upon contact with the surface of foods with high moisture content [154].

Several scientific studies have been conducted to evaluate the overall effect of adding crosslinking and strengthening agents, plasticizers, or additives with antimicrobial or antioxidant properties to gelatin-based films to improve its functional properties and increase the shelf life of food products $[155,156]$. The improvement of these properties occurs when the intermolecular interactions of the protein chains decrease under the influence of molecular structures that modify their hydrophilic character or promote the formation of strong covalent bonds in the protein film [157].

Zhao et al. demonstrated the feasibility of using natural extracts as new natural crosslinking agents for the modification of gelatin (type B, from bovine bone) by forming hydrogen bonds between water and free hydroxyl groups of amino or polyphenolic groups, which significantly increased the strength of the gel compared to untreated gelatin [158]. Combining gelatin with other biopolymers, such as whey proteins, starch, chitosan, or pectin, can also be a good way to improve the mechanical properties and water resistance of gelatin-based films [159-162].

\section{Approaches for the Production of Biopolymer-Based Films and Coatings}

The film production is a physico-chemical process based on the intermolecular interaction of the biopolymer with the components of the solution in order to create a stable polymer matrix [163]. The process of film formation depends on the ability of the biopolymer to form a continuous crystalline or amorphous structure; therefore, at the initial stage, it is important to determine the type of polymer, taking into account its properties and the features of the mechanism of structure formation [164].

The film formation from polysaccharides is based on the breaking of polymer chains and the creation of new hydrophilic, hydrogen bonds and Van der Waals forces due to 
electrolytic and ion crosslinking [165]. Protein-based biopolymers, compared to other film-forming materials, have distinctive features: conformational denaturation of the protein (changes in secondary, tertiary, and quaternary structures), the presence of electrostatic charges, and amphiphilic nature (the presence of hydrophilic and hydrophobic molecules) [166]. The mechanism of formation of films from protein consists of its denaturation under the influence of acid/alkaline, mechanical, or enzymatic treatments, heat treatment, and various solvents, which leads to the formation of new molecular bonds between the peptide chains-ionic and hydrogen bonds, Van der Waals forces, hydrophobic interactions, covalent polar and nonpolar bonds-disulfide bridges, and crosslinking [116,167-169]. The molecular interaction of the protein-polysaccharide complex occurs on the basis of Van der Waals and electrostatic forces, hydrophobic and hydrogen bonds, the effects of excluded volume (the balance between steric repulsion of chain links and effective short-term attraction), or through chemical binding, for example, the Maillard reaction - the interaction of amino acids with sugars, including fructose, glucose, etc. [170].

The films and coatings are obtained by dissolving, dispersing, and emulsifying the biopolymer in a specific solvent. According to the safety and biodegradability requirements for food films and coatings, water, ethanol and their mixtures, and organic acids are used as solvents [166]. Magnetic or electric stirrers are used for acceleration of the dissolution of biopolymers [171,172], and a vacuum pump or ultrasound equipment are used to remove air bubbles from the solution [173].

\subsection{Methods of Forming Edible Films}

Edible food films are usually made in two ways: wet and dry processes, using the appropriate methods (Figure 10) [174].

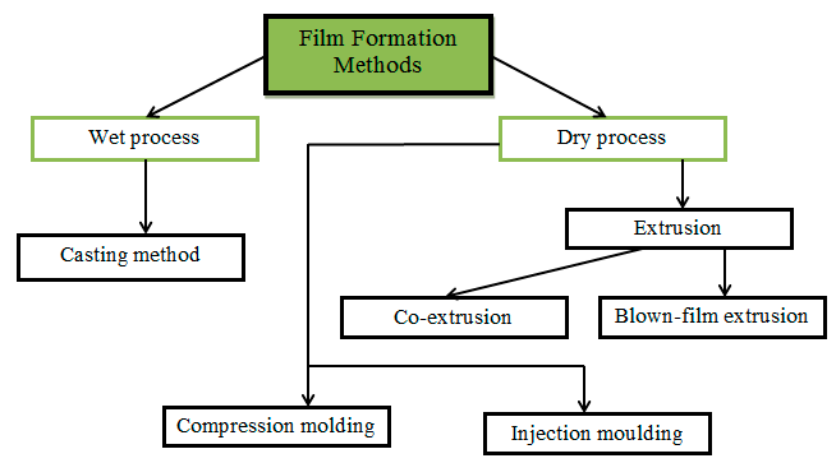

Figure 10. Film formation methods of biopolymers.

In the wet process, the film-forming components are mixed with a solvent, followed by drying the solution to obtain a food film [175]. The dry process consists of the formation of a film by heat treatment of a film-forming composition with a low solvent content [176]. In both processes, the film composition may include a single biopolymer or a combination of different biopolymers [177]. The wet process is mainly represented by the casting method [178], while the dry process is more variable — extrusion, injection molding, compression molding, co-extrusion, blown-film extrusion, and others [179-181].

Also, the films can have a mono-, di-, or multi- layer structure [182]. The production of di- and multi- layer films is carried out using the "layer by layer" technology, alternating solutions of biopolymers [183]. This method of film production is less common in the food industry because it is more labor-intensive, despite the fact that the finished films have improved barrier and mechanical characteristics [184].

\subsubsection{Casting Method}

The most common method of forming edible films is the casting method (Figure 11) referring to the wet process [185]. This method is widely used in laboratory and pilot scales because it is quite simple and does not require special equipment. The film production 
process includes 3 main stages: (1) solubilization of the biopolymer in the solvent; (2) casting of the solution in the mold; (3) drying of the solution [186,187].

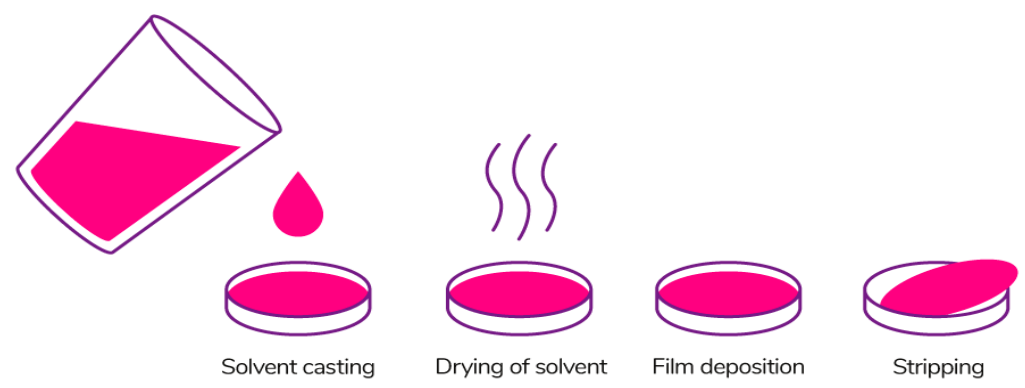

Figure 11. Casting method [186]. Reproduced with permission from Suhag, R., et al., Food Research International; published by Elsevier Ltd., 2020.

Various materials with low adhesion are used as forms for drying film-forming solutions. Teflon [188], glass coating (can be coated with a polyester film) [189], Petri dishes [190], Plexiglass [191], and polycarbonate plates [192] are the most common. Films are dried in various ways: under ambient conditions, with hot air, infrared energy, or microwave energy, which influence the formation of physico-chemical and mechanical properties [193].

The continuous casting method allows the films to be formed through the continuous flow of the biopolymer solution to a conveyor belt and then dried. The advantage of this method is the ability to choose such modes as the speed of the conveyor and the casting cycles of the solution, thereby adjusting the film thickness, temperature, and duration of drying [194]. This method makes it possible to obtain multilayer films [182].

The casting method is one of the most common. Dai et al. [195] studied the properties of films based on native and modified starches from various plant sources. Bagheri et al. [196] examined the effect of drying temperature on films prepared from sodium alginate with glycerin. Films plasticized with glycerin were cast using chitosan of two different molecular weights [197] and cellulose sulfate [198]. Liu et al. [199] investigated casting parameters for a mixture of gelatin, glycerin, and transglutaminase.

\subsubsection{Extrusion Method}

Extrusion is a continuous technological process of obtaining a film material by pushing the molten film-forming composition through a forming hole of a certain shape (Figure 12) [200]. This process involves several operations simultaneously: melting, mixing, dosing, and forming [201].

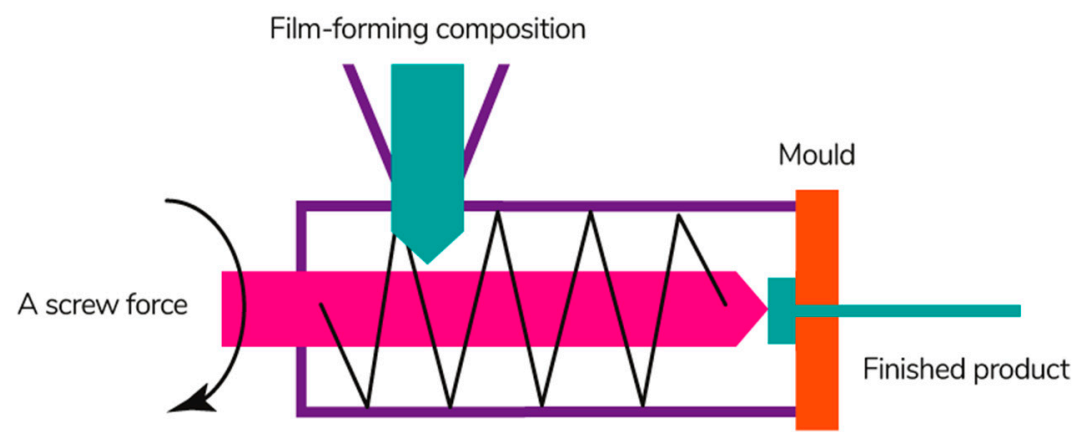

Figure 12. Extrusion process [186]. Reproduced with permission from Suhag, R., et al., Food Research International; published by Elsevier Ltd., 2020.

The method is based on the thermoplastic properties of polymers during plasticization and heating above their glass transition temperature under conditions of low water content [202]. Therefore, the thermoplastic properties of film-forming materials must be 
well studied for the production of films in this way. It is necessary to take into account the influence of plasticizers that lower the glass transition temperature and any other additives on the thermoplasticity of film-forming materials [174].

The production of films by extrusion includes 3 main stages: (1) loading the filmforming composition in the form of a gel, powder, or concentrated solution into the feed hopper; (2) adding the composite components and mixing; (3) heating and applying to a conveyor belt or drum, followed by cooling on metal shafts [203]. The structure of biopolymer films becomes more homogeneous during the extrusion process, as well as their physicochemical, mechanical, and barrier properties are improved [204,205].

Processing parameters such as die temperature, die construction, speed, and number of screws directly affect the properties of the film [206]. The construction of the dies is chosen depending on the viscosity of the solution and the required film thickness: (1) sheet dies or slotted; (2) flat-film designed for blown-film dies most often annular, less viscous solutions are suitable for them; (3) pipe and tubing dies (annular); (4) profile extrusion dies (all possible geometric shapes-square, $\mathrm{U}$ and T-shaped); (5) dies for co-extrusion dies [207]. Single- or twin-screw extruders are used in the laboratory and industry to mix the ingredients evenly [208]. The optimal properties of the film also depend on the speed of the screw.

González-Seligra et al. [209] noted that, at a screw speed of $40 \mathrm{rpm}$, the starch/glycerol films were characterized by a large amount of non-gelated starch and an uneven distribution of glycerol. At a speed of $80 \mathrm{rpm}$, more homogeneous films were obtained, but with rapid retrogradation of starch (the transition of starch from a soluble state to an insoluble state, leading to an increase in the rigidity and brittleness of the film) [210]. At a speed of $120 \mathrm{rpm}$, thermoplastic films with good mechanical properties (tensile strength) and slower starch retrogradation were obtained. Calderón-Castro et al. [211] used pretreatment with a double-screw extruder with a speed of $120 \mathrm{rpm}$ and a temperature of $100{ }^{\circ} \mathrm{C}$ with a cylindrical die and 3 heating zones to cast the extruded composition of physically modified starch. Compositions of pectin and starch with glycerol added in various combinations were extruded using a twin-screw extruder with a slit matrix to produce a thin film, which was dried in vacuum at room temperature before testing [212]. A twin-screw extruder with a cylindrical die was used to produce films from pectin and gelatin/sodium alginate [213]. A dry method was developed for the production of film sheets from rennet, acid casein, and sodium caseinate using a twin-screw extruder at a speed of $170 \mathrm{rpm}$ and a temperature of $10-75^{\circ} \mathrm{C}$ in various zones, and glycerin was added to the second zone; films from rennet casein, waxes, glycerin, and potassium sorbate were obtained by the same principle [122,214]. Collagen gels with plasma proteins, soy protein isolate, and gluten were processed using a single-screw extruder at $65 \mathrm{rpm}$, with saturated sodium chloride solutions at the exit of the annular die to remove the remaining moisture [215].

Blown-film extrusion is an alternative approach to achieve the industrial production of films, often using a single-screw extruder with an annular die and pressure shafts to pull the blown film [216]. This method is also used for the production of films from various biopolymers and their combinations: thermoplastic starch with plasticized chitosan processed in a twin-screw extruder to produce pellets with further blowing on a singlescrew mechanism with a ring head [217]; film blown from granules of plasticized sodium caseinate [218]; granules of starch and gelatin reinforced with cellulose, pre-made by compression molding at $100{ }^{\circ} \mathrm{C}$ using a single screw for subsequent blow molding [219].

Co-extrusion is the process of simultaneous extrusion of two or more materials to form a multilayer film or coating [220]. This method is also used for applying an edible film/coating to food products, for example, a film of calcium alginate formed on the surface of minced meat when they simultaneously pass through a co-extrusion die [221]; alginate films with various polysaccharides (carrageenan, pectin, starches, cellulose, and gums) applied for sausage products packaging [222]; sodium alginate films with additives used for packaging sausages made by dry fermentation [223]; collagen films [224]. 


\subsubsection{Compression Molding}

Compression molding is one of the oldest and most convenient methods of material processing [225]. The main stage of this process consists of heating the material under high pressure in the mold until it solidifies as a result of the formation of new bonds of biopolymer chains [226].

The extrusion method is often used to prepare the material before the main thermoforming process. Krishna et al. [227] obtained films from fish gelatin with glycerin by double-screw extrusion with further compression molding on teflon plates. Ceballos et al. [228] treated manioc starch with glycerin obtained on a double-screw extruder with a temperature-controlled hydraulic press. The films could be produced in one stage. A mixture of fish gelatin solution with glycerin and citric acid was subjected to compression molding using the caver laboratory press [229], as well as the composition of corn starch with glycerin and citric acid, previously mixed in a two-roll mill, followed by pressing [230]. Between the press and the film, sheets of various materials are used, for example, polytetrafluoroethylene [228], steel [230], aluminum [225], etc.

\subsubsection{Injection Molding}

Injection molding is a widely used process for mass production of plastic products [231], but it can also be used for the production of edible films and consists of three main stages-filling, packing, and cooling [232]. Pre-injection pressure temperature, injection pressure, and molding temperature are the most important parameters [233].

Yu et al. [234] applied the method of twin-screw extrusion for the subsequent formation of granules from plasticized wheat starch with or without polyethylene oxide. At the second stage, injection molding was performed to produce films. Cho et al. [235] demonstrated the ability to process wheat gluten and glycerin pellets on a three-phase screw injection molding machine by the compression molding method. Pea isolate films with glycerol addition were made using the Injection Molding System [233].

\subsection{Methods of Forming Coatings}

Edible coatings of food products could be prepared in different approaches: dipping, spraying, brushing, fluidized bed, and panning methods (Figure 13) [236].

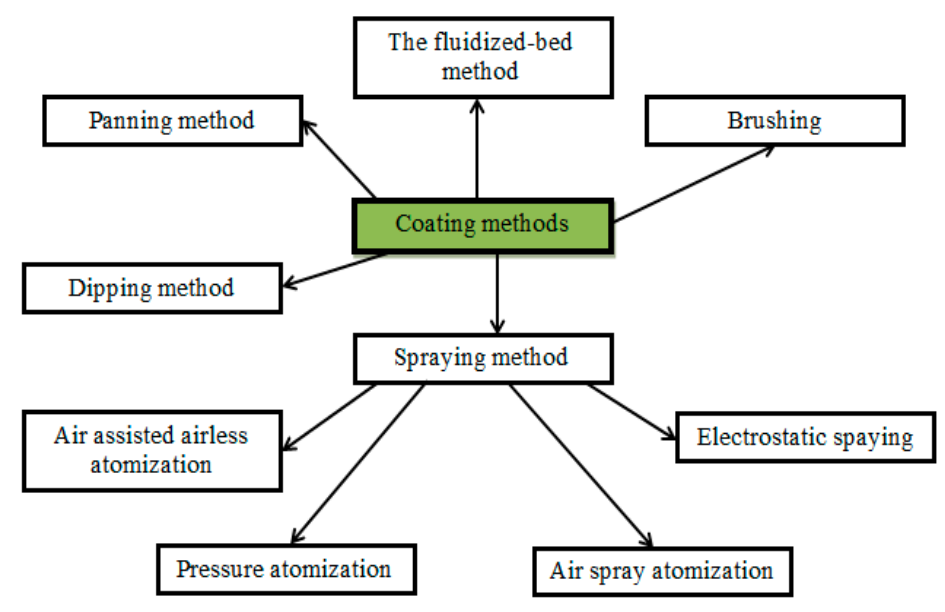

Figure 13. Coating methods.

The use of a certain method depends on the type of coated product $[237,238]$. The feasibility of using coatings is explained by the following functional features: barrier properties to gases $\left(\mathrm{O}_{2}, \mathrm{CO}_{2}, \mathrm{C}_{2} \mathrm{H}_{4}\right)$ and water, mechanical and optical properties, homogeneity, appearance, thickness, uniform distribution of the solution (wettability) on the surface, and adhesion (interaction between the surface of the product and the coating) [239].

The fluidized-bed and panning methods are difficult to perform and constitute in ways of spraying the film-forming solution: in the first case, it is produced on the surface 
of the fluidized bed and in the second case, it is sprayed on the processed product placed into a rotating pan [240,241]. Brushing is a method of applying the biopolymer solution with a brush [239]. Dipping and spraying are the most common methods due to simplicity and the low cost of the equipment [178]. The dipping method is most commonly used in the laboratory and is well suited for products with good surface adhesion [242], while spraying is convenient for implementation in industry [202].

\subsubsection{Dipping Method}

Dipping is a method of coating in which the product is immersed in a film-forming solution for a certain time, removed, and left to form a film on the surface of the product (Figure 14) [236]. If one dip is not enough, since part of the solution may not be completely distributed over the surface of the product, this procedure is repeated [243]. The properties of the coating depend on the density, viscosity, and surface tension of the solution [244].

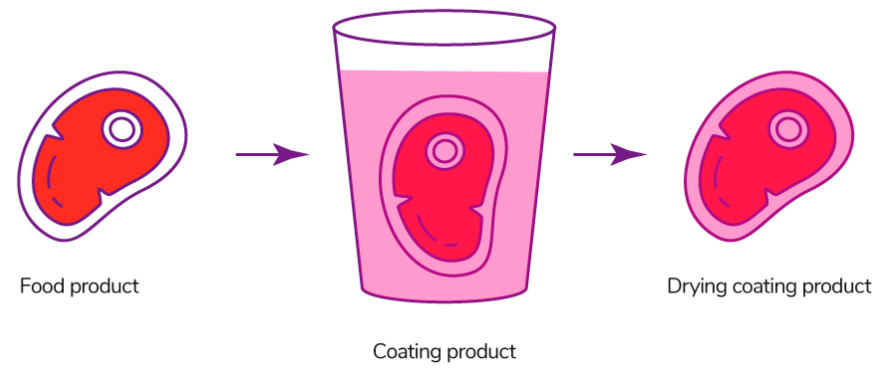

Figure 14. Dipping method [27]. Reproduced with permission from Mohamed, S.A.A., et al., Carbohydrate Polymer; published by Elsevier Ltd., 2020.

The disadvantage of the method is the possibility of forming an uneven and thick coating layer, which affects the appearance of the product, its shelf life, mechanical characteristics, and gas permeability [244]. Fruits are covered with a fairly thin layer, while vegetables and meat products have a thicker layer [245]. There are also a number of problems, such as possible dilution of the solution with pieces of product, resulting in the accumulation of product residues and the development of microbes in the immersion bath This method is more suitable for shapeless products [246].

The dipping method is used for coating melon slices with alginate solution [247], sliced pears with chitosan and/or carboxymethylchitosan solutions mixed with sodium chloride [248], rainbow trout fillet with sodium alginate solution [249], fresh kiwifruit with sodium alginate solution mixed with calcium chloride as a cross-linking agent [250], and papaya with k-carrageenan solution plasticized with glycerin [251].

\subsubsection{Spraying Method}

The spraying method (Figure 15) is carried out using spray equipment, from which the solution is applied to the surface of the product under pressure using special nozzles. The quality of the coating depends on a set of these parameters [178]. This method is suitable for fluid solutions, since more viscous ones make it difficult to spray [97]. The spraying method allows the product to be evenly coated, the thickness of the coating to be controlled, the temperature of the solution to be controlled, and large surfaces of products to be covered, but can have large losses of the solution to the ambient surroundings [177]. 


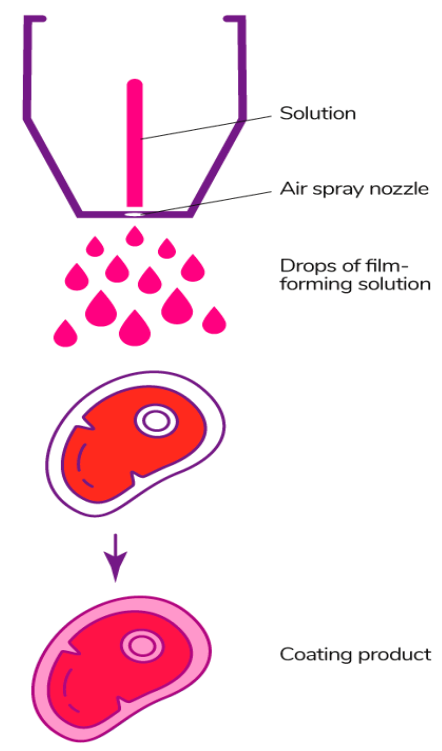

Figure 15. Spraying method.

There are several main types of spraying. Air spray atomization is the method when the film-forming solution is sprayed under low pressure mixed with atmospheric air. Pressure atomization is carried out without air and under high pressure. Air assisted airless atomization is a combined type of atomization, which consists of feeding the solution under high pressure and flattening with air at the last stage of processing for a better distribution of the composition on the surface of the product $[178,252]$. The latter two methods can be used for more viscous solutions, but the equipment for them has a high cost [186].

Electrostatic spraying is a modern method, which is spread enough [253]. An electric charge is given to small particles of the film-forming solution, which is moved under the influence of an electric field [254]. The main difference from typical spraying methods is a uniform coating layer and an increase in the adhesion on the product surface, which reduces losses [253].

The spraying method is used for coating Mozzarella cheese by electrostatic spraying with alginate, chitosan, and soy protein isolate solutions [255], freshly cut lotus roots by pressure atomization with xanthan gum [256], strawberry by electrostatic and usual spraying with sodium alginate [257], and products by electrostatic spraying with chitosan solutions of different deacetylation degrees [258].

\subsection{Edible Films Composition}

The most important properties of edible films are density, thickness, transparency, degree of swelling, thermal stability, mechanical strength, barrier properties to oxygen, and water vapor and safety [259]. The possibility of adding ingredients to the composition of edible films for improving the physico-chemical, mechanical, optical, and microbiological parameters compared with their basic compositions is of great interest to researchers [72,245]. Auxiliary components include plasticizers, crosslinking agents, and other additives [260].

The addition of a plasticizer is an important step in the preparation of solutions from proteins and polysaccharides, which allow the formation of a brittle structure of edible films to be excluded [186]. Most plasticizers contain hydroxyl groups that form hydrogen bonds with biopolymers and increase the free space and flexibility of the polymer matrix [261]. Water, mono-, di-, and oligosaccharides (glucose, sucrose, and fructose) [262], polyatomic alcohols (glycerin and sorbitol) [263], and lipids and their derivatives (lecithin, oleic acid, and waxes) [264] are the main plasticizers.

Crosslinking agents are used to improve the hydration, mechanical, and barrier properties of films and coatings based on proteins and polysaccharides [265]. The process 
of crosslinking consists of the formation of a three-dimensional structure of the solution by binding the polymer chains with covalent or non-covalent bonds, which leads to an increase in the hydrophobicity of the biopolymer [4]. The choice of crosslinking agents depends on the chemical structure, the presence of active groups, and the molecular weight of the biopolymer, as well as its compatibility with the crosslinking agent [266]. Crosslinking agents and plasticizers must be safe and approved for use in the food industry [267].

\subsubsection{Edible Starch Films}

Starch is used to produce biodegradable films due to its ability to form a continuous matrix and low permeability to oxygen [268]. The production of edible films from starch is based on the process of gelatinization, i.e., the destruction of the native structure of the biopolymer. Gelatinization is accompanied by a retrogradation process, which includes a reduction of the amount of water-soluble substances in the dissolved starch [269]. The resulting mixture consists of solubilized amylose and partially residual amylopectin granules [270]. Amylose is more prone to retrogradation, the rate of which depends on the amount of starch in the film, the ratio of amylose:amylopectin, their structure, etc. [271]. It leads to undesirable changes in the mechanical and thermal characteristics of the film [272].

A sufficient amount of water (at least $65 \%$ of the biopolymer mass) and exposure to high temperatures ranging from 60 to $95^{\circ} \mathrm{C}$ are important conditions for hydration of starch molecules for the film processing $[273,274]$. Water is a good plasticizer, but it is often not enough to obtain the necessary elasticity of the film [275]. The evaporation of water during the drying process can lead to increasing fragility of the starch films [276]. It is necessary to use a plasticizer, such as citric acid and glycerin $[277,278]$, and/or modified starch to reduce its hydrophilic properties $[175,279]$. The characteristics of starch films depend on the source of the starch, the content and type of plasticizer, and the processing conditions [175]. The high content of amylose in starch results in an elevation of the strength properties of the obtained films since amylose can easily form crystallites and new bonds [269].

Nawab et al. [280] used starch plasticized with glycerin and/or sorbitol from mango seeds for coating of nuts. Mehyar and Han [281] studied mechanical and barrier properties of rice and pea starch films with a high content of amylose and plasticized with glycerin. The properties of cassava starch with glycerin, citric acid, and without it were investigated by Chiumarelli et al. [282] for preserving the quality of mango during the entire shelf life.

\subsubsection{Edible Cellulose Films}

Cellulose is insoluble in polar solvents, such as water, alcohols, etc. [283], due to its complex and dense linear structure, which includes a large number of intra- and intermolecular hydrogen bonds [284,285], as well as its ability to crystallize [286]. The solubility of cellulose is assumed to be related to its amphiphilic nature and hydrophobic interactions in the polymer structure [287,288].

A lot of studies has focused on finding new ways to dissolve cellulose using the following unusual solvents: N-methylmorpholine N-oxide (NMMO) [285], ionic liquids (a group of organic salts in the liquid state) [289], non-aqueous solvent $\mathrm{LiCl} / \mathrm{N}, \mathrm{N}$-dimethylacetamide (LiCl/DMAc) [290], aqueous solution of $\mathrm{NaOH}$ [291], aqueous solution of alkalis/urea and aqueous solution of $\mathrm{NaOH}$ /thiourea [292], mixture of tetra-n-butylammonium fluoride trihydrate $\left(\mathrm{TBAF} \times 3 \mathrm{H}_{2} \mathrm{O}\right.$ ) and dimethyl sulfoxide (DMSO) [293], hydrates of inorganic molten salts, as an example $\mathrm{ZnCl}_{2} \times 4 \mathrm{H}_{2} \mathrm{O}$ [294], and aqueous solutions of metal complexes consisting of transition metal ions and nitrogenous ligands, the most well-known of which are cuprammonium hydroxide (Cuam) and bis(ethylenediamine) copper (II) hydroxide (Cuen) [295].

The physical regeneration of a cellulose solution with coagulants (anti-solvents or nonsolvents) is one of the methods of obtaining films and coatings [285]. Zhang et al. [296] used $\mathrm{H}_{2} \mathrm{SO}_{4}, \mathrm{CH}_{3} \mathrm{COOH}, \mathrm{H}_{2} \mathrm{SO}_{4} / \mathrm{Na}_{2} \mathrm{SO}_{4}, \mathrm{Na}_{2} \mathrm{SO}_{4}$, etc., as coagulants for following cellulose regeneration in $\mathrm{NaOH} /$ urea. Geng et al. [297] studied a mixture of acetone with water for cellulose precipitation with following regeneration in $\mathrm{NaOH} /$ urea/water. The obtained 
films have good mechanical and barrier properties [298]. Cellophane and cuprofen are the main products prepared from regenerated cellulose and used in the food, medical, and other industries. However, they are losing popularity due to the high cost of production, as well as low barrier properties [299].

Films made of cellulose derivatives dissolve in polar solvents, including water, alcohols, etc., and, therefore, are of interest to researchers [252]. Cellulose derivatives have good mechanical and barrier properties to lipids and gases, including oxygen $\left(\mathrm{O}_{2}\right)$ and carbon dioxide $\left(\mathrm{CO}_{2}\right)$ [300]. The production of films from carboxymethylcellulose (CMC) and cellulose nanocrystals (CNC) is quite common. Cellulose nanocrystals or nanocellulose is a highly crystalline material with improved thermal, mechanical, and barrier properties, and is obtained by acid hydrolysis [301]. It is noted that the nanofiber of CMC has a negative charge and forms a film in the hydrogel state due to ion crosslinking [302]. Thus, Oun and Rhim [303] studied CMC films plasticized with glycerin with or without CNC from rice, barley, and wheat straw. Li et al. [304] used CMC with CNC from pea husks, and Singh et al. [305] used sodium CMC and hydroxyethylcellulose with citric acid as a crosslinking agent. A coating of blueberries from CMC were prepared with the addition of plasticizers-sorbitol and propylene glycol [306].

$\mathrm{CNC}$ in a matrix with another biopolymer form a percolated grid linked by hydrogen bonds [307,308]; therefore, cellulose is used as a reinforcing component [309], for example, in films of oxidized starch [310] or pea starch with CMC hydrogel [311,312], mango puree [313], and plasticized gelatin [314]. Moreover, CNC could be used for improving the barrier properties of chitosan films to water vapor [315,316].

\subsubsection{Edible Pectin Films}

Pectins are soluble in acid and water, most often used as a gelling agent [317]. Many studies consider homogalacturonan, rhamnogalacturonan I, and rhamnogalacturonan II the main monomers of pectin [318]. Pectins have a large number of negatively charged carboxyl groups in the chemical structure and exhibit the ability to interact with metal cations and can bind the active ingredients [319].

The molecular weight of the biopolymer, the degree of esterification, and acetyl esterification depend on the source and extraction conditions, and affect the gelation, texture, and stability of the pectin systems [320]. The degree of methoxylation of galacturonic acid residues is the main factor determining the functionality of pectin [321]. Gelation of low-methoxylated pectin $(\mathrm{DM}<50)$ involves electrostatic interactions between cations and negatively charged regions of polymer chains [322]. This model of interaction is called "egg box"-ionic bonds through calcium bridges between carboxyl groups [323]. The stabilization of the system between two adjacent chains of "egg boxes" can occur by van der Waals forces, hydrogen bonds, and electrostatic interactions [321]. Amidated pectin is characterized by a low content of methoxyl groups. It requires less calcium ions to form a gel, is more stable to $\mathrm{pH}$ fluctuations compared to non-amidated pectin, and as a result, it is less sensitive to precipitation with a large amount of calcium, and its gels are thermally reversible [72]. Pectin with a high content of methoxyl groups $(\mathrm{DM}>50)$ has a gel-forming ability in an acidic $\mathrm{pH}<3.5$ in the presence of cosolute with a high concentration, which promotes hydrophobic interactions between methoxyl groups by reducing the activity of water [321]. A low $\mathrm{pH}$ is necessary to reduce the dissociation of carboxyl groups, which can form hydrogen bonds with secondary alcohol groups [323].

It is known that pectin gels can be formed due to the formation of covalent crosslinks [317], e.g., feruloylated pectins have ferulic acid in the side chains, which can be cross-linked using the oxidative enzymes laccase or peroxidase and form a covalently bound structure, since they have poor gelling properties [324]. The functional properties of such gels differ from those formed by other bonds: the rigidity of the gel increases and the elasticity decreases [321].

Pectin films have good mechanical and barrier properties to oxygen, high resistance to fats, but low stability to moisture [325]. Pectin films have a brittle structure, while the 
addition of a plasticizer does not always lead to high elasticity, so the use of crosslinking agents has a positive effect on the mechanical characteristics of such films [326,327]. Low pectin methoxyl from the cocoa peel was plasticized with glycerin/sorbitol [328], pectin film without additives was used for freshly cut pears [329], calcium lactate as a cross-linking agent was added to low pectin methoxyl for coating of melon [330], while high pectin methoxyl was plasticized with sorbitol for mango dipping [331].

\subsubsection{Edible Chitosan Films}

Chitosan has good film-forming properties and is characterized by an increased viscosity of the solution during hydration [332]. Antimicrobial activity is one of the features of chitosan due to the presence of active amino groups in the structure [333]. The biopolymer is insoluble in water and usual organic solvents [334]. Its solubility depends on the degree of deacetylation, the location of acetyl groups along the main chain, and the molecular weight. Chitosan is soluble in dilute acid solutions at a $\mathrm{pH}$ below 6.0-6.3 due to the presence of amino groups [335]. The mechanical characteristics of the film improve when increasing the molecular weight of the biopolymer [336]. The polycationic properties of chitosan allow the formation of films by breaking the fragments of the polymer chain and then converting them into a film matrix or gel, for example, by evaporation of the solvent, creating hydrophilic and hydrogen bonds and/or electrolytic and ionic crosslinking [337]. Chitosan can effectively improve the mechanical and barrier properties of the film due to the electrostatic attraction [338].

Chitosan-based films are transparent, flexible, and durable [339], have good resistance to fats, selective permeability to carbon dioxide $\left(\mathrm{CO}_{2}\right)$ and oxygen $\left(\mathrm{O}_{2}\right)$, but are very sensitive to moisture [340,341]. Chitosan is also used to enhance the emulsifying effect, reduce the acidity, and stabilize the color of the films [342]. Chitosan is not a thermoplastic material, as it decomposes to the melting point. Therefore, it cannot be extruded, and the films cannot be heat-sealed, but this problem is solved by using it in conjunction with thermoplastic polymers [343].

Chitosan was applied as the main biopolymer for creating edible films in many studies. Chitosan plasticized with glycerin was used for films production [335,344], a film-forming solution of chitosan in a 1\% solution of acetic acid was used for dipping sardines [345] and its mixture with glycerin was used for packaging Mozzarella cheese [346] and rainbow trout together with high hydrostatic pressure technology [347], and a film based on chitosan dissolved in deionized water with the addition of glacial acetic acid was wrapped around the fillet of sea bass [348].

\subsubsection{Edible Alginate Films}

Alginate is a linear polysaccharide with moderate branching. Due to this, it is able to form films with high strength [349]. Sodium, potassium, and ammonium alginates are highly soluble in water, while alginic acid and calcium alginate are not [97]. This anionic polysaccharide with carboxyl groups in each monomer block can react with cations of polyvalent metals (calcium, magnesium, manganese, aluminum, iron, etc.), which makes it possible to obtain strong water-resistant films [350].

The composition, sequence, and ratio of alginate monomers $\mathrm{M}(\beta-\mathrm{d}-\mathrm{mannuronic}$ acid)/G ( $\alpha$-l-guluronic acid) directly affect the properties of alginate, alginate gels, and films [351]. A large number of G-monomers indicates the ability to form strong films, while the predominance of $\mathrm{M}$-monomers often leads to more elastic films [352]. The unique property of alginates is based on the interaction with metal cations, especially with calcium ions [353]. The ions form bonds between the $\mathrm{M}$ and $\mathrm{G}$ blocks, resulting in a stable and ordered three-dimensional "egg box" model grid [354]. The formation of bonds occurs due to the length and selectivity of the G blocks, and the M and MG blocks are practically devoid of selectivity [355]. The crosslinking process is used to improve resistance to water, mechanical strength, cohesion and rigidity, and the ability to retain active components in a polymer matrix [244]. The process of interaction with ions is rapid; therefore, a fast-setting 
and thermally stable gel or film is formed, as a result of which the homogeneity of the resulting material can be disrupted, so it is important to control the rate of ion release [295].

Alginates form transparent, homogeneous, water-soluble films with high resistance to fats and low permeability to oxygen $[353,356]$. In a number of studies, alginates are used as the main component of biofilms; for example, the ratio of components was selected using the surface response methodology in films made of sodium alginate with glycerin crosslinked with calcium chloride and citric acid [357]; sodium alginate crosslinked with calcium chloride [354,358], and sodium alginate plasticized with glycerin [196]; alginate films plasticized with various types of compounds-PEG-8000, glycerin, fructose, or sorbitol [262].

\subsubsection{Edible Casein Films}

Caseins can bind ions and small molecules, have outstanding surface-active, stabilizing, and emulsifying properties, as well as good gel-forming and water-binding ability [359]. The preparation of edible films from aqueous solutions of caseinate occurs by its solubilization due to the disordered structure of the protein's helix [360]. However, the effect of a buffer solution with $\mathrm{pH} 4.6$ leads to the formation of water-insoluble substances, since the protein is in the isoelectric point [361,362].

Caseinates can form intermolecular hydrogen, hydrophobic and electrostatic bonds, which lead to increased interactions between the chains [363]. The structure of the biopolymer matrix is stabilized by hydrophobic, ionic, and hydrogen bonds [115], while binding with hydrophobic molecules occurs by hydrophobic interactions, Van der Waals forces, and hydrogen bonds [362].

Milk proteins form elastic transparent films without odor [113]. The casein films demonstrate resistance to denaturation and/or coagulation and remain stable in a wide range of temperatures, $\mathrm{pH}$, and salt concentrations [364]. Casein-based films for food packaging have good mechanical properties due to the presence of calcium ions and salts of other metals, low oxygen permeability, poor elasticity, high sensitivity to moisture, as well as allergenicity $[183,365]$. Calcium caseinate films have better barrier properties but are more rigid, whereas sodium caseinate films have better optical properties and elongation under tension $[363,366]$.

The application of caseins in the production of films is quite widespread, for example, films from casein cross-linked by transglutaminase [365] or tannic acid [114], calcium or sodium caseinates and $\beta$-casein isolate plasticized with glycerin $[115,367,368]$, films based on casein treated with carbon dioxide [369], or cold plasma with dielectric barrier discharges for improving the functional properties of the films [370].

\subsubsection{Edible Collagen Films}

Type I collagen has a fibrous structure and is most often used for films processing [371]. The main amino acid composition of collagen includes glycine, proline, and hydroxyproline [372]. The amino acid composition and molecular weight affect the type and number of interactions involved in the stabilization of the protein matrix, which include disulfide covalent bonds, hydrogen bonds, electrostatic attraction forces, and hydrophobic interactions [373]. A hydrogen bond is formed between the glycine and the amide group in the adjacent chains, which is the main factor in the stabilization of the collagen triple helix [374]. Collagen is a hydrophilic protein, since it contains more acidic, basic, and hydroxylated amino acid residues than lipophilic ones [375].

Collagen has two main properties: gelling, which includes gelation, thickening, etc., and surface activity, including emulsification, adhesion and cohesion, film-forming ability, etc. [145]. The collagen film has good barrier properties to moisture, oxygen $\left(\mathrm{O}_{2}\right)$, prevents the migration of dissolved substances, provides structural integrity and vapor permeability, but has disadvantages, including a rough surface and low thermal stability [376]. The low mechanical strength of the collagen films often leads to breaks during packing [375]. Crosslinking or aging treatments are two ways to solve these problems [377]. There are 
many additives that can improve the physical and chemical properties of films by chemical crosslinking-formaldehyde, carbodiimide, hexamethylene-1,6-diaminocarboxysulfonate, glutaraldehyde, heparin, transglutaminase, etc. [375], but most of them are cytotoxic [377]. Aging treatments is considered a method of physical crosslinking accompanied with changes in orientation of the collagen fibers, for its implementation, temperature, humidity, and time parameters can be used. The optimal conditions for improving the physical and chemical properties, such as mechanical parameters and reduced water absorption capacity, could be obtained by varying the aging parameters of the collagen films [375].

Collagen-based films have also been used in the food industry for a long time. For film processing, the extracted collagen is pre-treated with an acidic and/or alkaline solution [378], and the collagen fiber plasticized with glycerin [379] or lyophilized collagen are crosslinked with transglutaminase [380]. Many meat products and feed are packed in a collagen film [381].

\subsubsection{Edible Gelatin Films}

Gelatin is a hydrolyzed form of collagen [176]. The hydrolysis conditions (catalyst and its concentration, the process temperature and duration, etc.) determine the functional characteristics of the hydrolysate [153]. Collagen consisting of f-chains with a molecular weight of about $100 \mathrm{kDa}$ can be dissolved in acid during hydrolysis without changing its original triple helix configuration. Non-covalent bonds are broken during this process [382]. The breaking of both hydrogen and covalent bonds occur during subsequent heat treatment; this leads to the destabilization of the triple helix as a result of the helixhelix transition [383] and the transformation into soluble gelatin [384]. The amino acid composition and molecular weight are the main factors affecting the physical and structural properties of gelatin, which form the mechanical and barrier properties, and the thermal stability of the obtained films and gels [384,385].

Gelatin demonstrates a film-forming ability and forms transparent, slightly colored films with high elongation [386], can form large grids due to its large molecular weight, and incorporate various components [314]. Gelatin-based materials have some serious application limitations due to their high sensitivity to moisture, solubility in water, poor mechanical properties (brittleness), and low thermal stability [387,388]. Hydrophobic plasticizers, such as citric acid esters, can be used for improving the barrier properties to water vapor [389]. Gelatin is dissolved in hot water and the solution is poured into a container and dried to obtain an edible film [390]. The edible films become denser, and the mechanical properties improve with an increase in the protein content, but the permeability to water vapor decreases [27].

Plasticized gelatin from farm animal and fish skin [391,392] or gelatin cross-linked with alginate dialdehyde are used for edible film processing [393]. Sorbitol [394] and triacetin [395] also could be used as plasticizers for films production from cattle and pork gelatin.

\subsection{Ways of Edible Films Improving, Production and Application in Food Pachaging Based on Biopolymer Properties}

Animal proteins and natural polysaccharides have both advantages and disadvantages caused by its chemical nature and structure. Taking into account these characteristic, undesirable properties could be improved, while positive ones could be considered for films and coatings production for each biopolymer and type of food product. The summarized information is presented in Table 1. 
Table 1. The main characteristics of packaging materials based on animal proteins and natural polysaccharides and ways of its improving, production and application.

\begin{tabular}{|c|c|c|c|c|c|c|}
\hline Advantages & Disadvantages & Approaches for Properties Improving & $\begin{array}{c}\text { Recommended } \\
\text { Film-forming Solution }\end{array}$ & $\begin{array}{l}\text { Appropriate form and } \\
\text { Ways of Production }\end{array}$ & $\begin{array}{l}\text { Type of Packaged } \\
\text { Food }\end{array}$ & References \\
\hline \multicolumn{7}{|c|}{ Starch } \\
\hline $\begin{array}{l}\text { Strong and flexible structure } \\
\text { Transparency } \\
\text { Resistance to fats and oils } \\
\text { Good strain at break } \\
\text { Tasteless } \\
\text { Odorless } \\
\text { Very low oxygen } \\
\text { permeability }\end{array}$ & $\begin{array}{c}\text { Hydrophilicity } \\
\text { Low water stability } \\
\text { High moisture sensitivity } \\
\text { High water vapor permeability } \\
\text { Retrogradation phenomena } \\
\text { Brittle behavior at room } \\
\text { temperature } \\
\text { Poor mechanical properties and } \\
\text { processability }\end{array}$ & $\begin{array}{c}\text { Plasticizers addition } \\
\text { Compatibilizers addition } \\
\text { Structure modification (TPS) } \\
\text { Chemical modification (acetylation, } \\
\text { hydroxypropylation, acid modified, etc.) } \\
\text { Crosslinking (glutaraldehyde, sodium } \\
\text { trimetaphosphate, citric acid, etc.) } \\
\text { Physical modification (deep freezing and thawing, } \\
\text { B-type X-ray diffraction, extrusion heating and } \\
\text { fluidized bed heating, ultrasound waves, microwave } \\
\text { radiation, osmotic pressure, pulsed electric field, etc.) } \\
\text { Gelatinization transition temperatures Enzymatic } \\
\text { hydrolysis or modification } \\
\text { Elevation of amylose content } \\
\text { Micro- and nanosized fillers (starch nanocrystals or } \\
\text { nanoparticles) } \\
\text { Composite materials and blending }\end{array}$ & $\begin{array}{l}\text { Starch 2-4 wt \%, } \\
\text { 15-30\% of glycerol or } \\
\text { sorbitol (mainly } \\
\text { glycerol) }\end{array}$ & $\begin{array}{c}\text { Films } \\
\text { Wet method (casting) } \\
\text { Dry methods (extrusion, } \\
\text { injection moulding, and } \\
\text { compression moulding) } \\
\text { Coatings } \\
\text { Dipping and spraying }\end{array}$ & $\begin{array}{l}\text { Fruit, vegetables, } \\
\text { berries, meat and } \\
\text { some meat products }\end{array}$ & $\begin{array}{l}{[175,269,396-} \\
\quad 406]\end{array}$ \\
\hline \multicolumn{7}{|c|}{ Cellulose } \\
\hline
\end{tabular}


Table 1. Cont.

\begin{tabular}{|c|c|c|c|c|c|c|}
\hline Advantages & Disadvantages & Approaches for Properties Improving & $\begin{array}{c}\text { Recommended } \\
\text { Film-forming Solution }\end{array}$ & $\begin{array}{l}\text { Appropriate form and } \\
\text { Ways of Production }\end{array}$ & $\begin{array}{c}\text { Type of Packaged } \\
\text { Food }\end{array}$ & References \\
\hline \multicolumn{7}{|c|}{ Pectins } \\
\hline $\begin{array}{c}\text { Good oxygen, aroma, and } \\
\text { lipid barriers } \\
\text { Transparent } \\
\text { Flavorless } \\
\text { Colorless } \\
\text { Tasteless }\end{array}$ & $\begin{array}{c}\text { Hydrophilicity } \\
\text { Subjected to re-dissolution in } \\
\text { water or destruction } \\
\text { in high humidity conditions } \\
\text { Brittle and stiff structure } \\
\text { Poor moisture barriers } \\
\text { Not strong } \\
\text { Poor mechanical characteristics }\end{array}$ & $\begin{array}{c}\text { Plasticizers addition (glycerol, acetylated } \\
\text { monoglycerides, poly-ethylene glycol, and sucrose) } \\
\text { Crosslinking (ionomers formation, calcium ions) } \\
\text { Composite materials and blending }\end{array}$ & $\begin{array}{l}1-3 \mathrm{wt} \% \text { pectin, } 45-50 \% \\
\text { of glycerol, } 1-2 \% \text { of } \\
\text { calcium chloride }\end{array}$ & $\begin{array}{l}\text { Coatings (mainly) } \\
\text { Dipping, brushing and } \\
\text { spraying } \\
\text { Films } \\
\text { Wet method (casting) }\end{array}$ & $\begin{array}{l}\text { Fruits, berries and } \\
\text { vegetables, } \\
\text { meat and poultry } \\
\text { products with } \\
\text { limitations }\end{array}$ & $\begin{array}{r}{[72,78,325} \\
328,406,418]\end{array}$ \\
\hline \multicolumn{7}{|c|}{ Chitosan } \\
\hline $\begin{array}{l}\text { Low oxygen and } \mathrm{CO}_{2} \\
\text { permeability } \\
\text { Antimicrobial properties } \\
\text { Antioxidant activity } \\
\text { Forms strong films } \\
\text { Excellent } \\
\text { film-forming behavior } \\
\text { Compatibility with other } \\
\text { substances } \\
\text { Good mechanical properties } \\
\text { Transparent } \\
\text { Flavorless } \\
\text { Colorless } \\
\text { Tasteless } \\
\text { Acts as a chelating agent }\end{array}$ & $\begin{array}{c}\text { High water sensitivity } \\
\text { Highly permeable to water } \\
\text { vapor } \\
\text { Low mechanical and thermal } \\
\text { stability } \\
\text { Brittleness } \\
\text { Stiffness }\end{array}$ & $\begin{array}{c}\text { Addition of neutral lipids, fatty acids waxes and clay } \\
\text { Addition of cross-linking agents } \\
\text { Chemical modifications (N-methylation, alkylation) } \\
\text { Irradiation } \\
\text { Ultrasonic treatments } \\
\text { Grafting } \\
\text { Enzyme treatment } \\
\text { Plasticizers addition (glycerol, xylitol, and sorbitol) } \\
\text { Thermomechanical treatment } \\
\text { Complexation } \\
\text { Surface coating } \\
\text { Natural deep eutectic solvents s based on choline } \\
\text { chloride prepared } \\
\text { with malic acid (MA), lactic acid (LA), citric acid, and } \\
\text { glycerol } \\
\text { Composite materials and blending }\end{array}$ & $\begin{array}{c}1-2 \% \text { of chitosan }(>90 \% \\
\text { DDA) in } 1 \% \text { acetic } \\
\text { acid/malic/lactic/citric } \\
\text { acid (mainly acetic } \\
\text { acid), } \\
20-30 \% \text { of glycerol }\end{array}$ & $\begin{array}{c}\text { Films } \\
\text { Wet method (casting) } \\
\text { Dry methods (extrusion, } \\
\text { compression moulding) } \\
\text { Coatings } \\
\text { Dipping and spraying }\end{array}$ & $\begin{array}{l}\text { Fruits, berries and } \\
\text { vegetables, } \\
\text { Meat, fish and } \\
\text { poultry }\end{array}$ & $\begin{array}{l}{[26,46,335,} \\
340,406,419- \\
426]\end{array}$ \\
\hline
\end{tabular}


Table 1. Cont.

\begin{tabular}{|c|c|c|c|c|c|c|}
\hline Advantages & Disadvantages & Approaches for Properties Improving & $\begin{array}{l}\text { Recommended } \\
\text { Film-forming } \\
\text { Solution }\end{array}$ & $\begin{array}{l}\text { Appropriate form and } \\
\text { Ways of Production }\end{array}$ & $\begin{array}{c}\text { Type of Packaged } \\
\text { Food }\end{array}$ & References \\
\hline \multicolumn{7}{|c|}{ Alginate } \\
\hline \multicolumn{7}{|c|}{ Casein } \\
\hline
\end{tabular}


Table 1. Cont.

\begin{tabular}{|c|c|c|c|c|c|c|}
\hline Advantages & Disadvantages & Approaches for Properties Improving & $\begin{array}{c}\text { Recommended } \\
\text { Film-forming Solution }\end{array}$ & $\begin{array}{l}\text { Appropriate form and } \\
\text { Ways of Production }\end{array}$ & $\begin{array}{c}\text { Type of Packaged } \\
\text { Food }\end{array}$ & References \\
\hline \multicolumn{7}{|c|}{ Collagen } \\
\hline $\begin{array}{l}\text { Mechanical resistance } \\
\text { Good barriers to oxygen } \\
\text { and carbon dioxide } \\
\text { Adhere well } \\
\text { to hydrophilic surfaces } \\
\text { Gel strength } \\
\text { Good melting temperature } \\
\text { Shape and stability } \\
\text { Good mechanical properties }\end{array}$ & $\begin{array}{l}\text { High sensitivity to moisture } \\
\text { Poor barriers to moisture } \\
\text { Not so strong } \\
\text { Prone to rupture } \\
\text { Seepage phenomenon } \\
\text { Anisotropy } \\
\text { Dependence of properties on } \\
\text { alignment direction of collagen } \\
\text { fiber } \\
\text { Poor quality, particularly in } \\
\text { terms of strength and elasticity }\end{array}$ & $\begin{array}{c}\text { Cross-linking (gluteraldehyde, carbodimide, } \\
\text { transglutarninase, keratin, metal ions) } \\
\text { Plasticizers addition (glycerol or sorbitol) } \\
\text { UV irradiation } \\
\text { High pressure treatment } \\
\text { Organic acid treatment } \\
\text { Enzymatic treatments (proteases such as papain, } \\
\text { bromolain, ficin, fungal protease, trypsin, } \\
\text { chymotrypsin, or pepsin) } \\
\text { Aging treatment } \\
\text { Regeneration } \\
\text { Composite materials and blending }\end{array}$ & $\begin{array}{l}3-8 \mathrm{wt} \%(0-10 \%) \\
\text { of collagen }\end{array}$ & $\begin{array}{l}\text { Casings or films } \\
\text { Extrusion (wet and dry } \\
\text { spinning technology) } \\
\text { and co-extrusion }\end{array}$ & $\begin{array}{l}\text { Meat and meat } \\
\text { product (especially } \\
\text { casings for sausages) }\end{array}$ & $\begin{array}{l}{[224,406,442-} \\
446]\end{array}$ \\
\hline \multicolumn{7}{|c|}{ Gelatin } \\
\hline $\begin{array}{c}\text { Good film-forming } \\
\text { properties } \\
\text { Biocompatibility } \\
\text { Transparent } \\
\text { Low oxygen permeability } \\
\text { Absence of an appreciable } \\
\text { odour } \\
\text { Transparent } \\
\text { Tasteless } \\
\text { Gel strength }\end{array}$ & $\begin{array}{c}\text { Low strength } \\
\text { Inelasticity } \\
\text { Brittleness } \\
\text { Limited thermal stability } \\
\text { Limited mechanical properties } \\
\text { High sensitivity to moisture } \\
\text { Poor barriers to moisture }\end{array}$ & $\begin{array}{c}\text { Cross-linking (genipin, transglutaminase, natural } \\
\text { extracts, glutaraldehyde) } \\
\text { Plasticizers addition (propylene glycol, ethylene } \\
\text { glycol, glycerol or sorbitol, Sucrose, oleic acid, citric } \\
\text { acid, tartaric acid, malic acid, PEG of different } \\
\text { molecular weights, mannitol, EG, DEG, TEG, EA, di } \\
\text { ethanol amine (DEA) and TEA) } \\
\text { Inorganic and organic materials addition } \\
\text { Physical treatment (heating or irradiation) } \\
\text { Maillard reaction } \\
\text { Chemical modification (acetylation, deamidation, } \\
\text { glycation, etc.) } \\
\text { Composite materials and blending }\end{array}$ & $\begin{array}{l}2-5 \mathrm{wt} \% \text { of gelatin, } \\
10-30 \% \text { of glycerol }\end{array}$ & $\begin{array}{c}\text { Films } \\
\text { Wet method (casting) } \\
\text { Dry methods (extrusion, } \\
\text { blown-extrusion) } \\
\text { Coatings } \\
\text { Dipping and spraying } \\
\text { (dipping is more } \\
\text { spread) }\end{array}$ & $\begin{array}{c}\text { Various meat } \\
\text { products, poultry, } \\
\text { fish, vegetables and } \\
\text { fruits }\end{array}$ & $\begin{array}{l}{[113,139,406,} \\
447-455]\end{array}$ \\
\hline
\end{tabular}


Edible films based on one biopolymer are often characterized high sensitivity to moisture and and poor barrier to water wapor due to its hydrophilicity nature, as well as brittleness and insufficient mechanical properties. These disadvantages could be solved by different modifications, cross-linking agents and plasticizers addition, and especially by creating composite films and blending.

\subsection{Edible Composite Films}

The application of various combinations of biopolymers is of interest to researchers because it can eliminate the disadvantages of single-component films and achieve the desired barrier and physical-mechanical characteristics of edible films [163]. The properties of edible films and coatings can be changed based on the hydrophobic-hydrophilic characteristics of certain biopolymers [244]. Hydrophobic molecules have a positive effect on the barrier properties to moisture [456]. Oppositely, hydrophilic molecules contribute to the production of materials with higher strength characteristics and low gas permeability [457]. Table 2 shows some variations of edible films obtained by mixing different types of biopolymers and auxiliary ingredients to improve the properties of composite films. 
Table 2. Examples of composites edible films.

\begin{tabular}{|c|c|c|c|c|}
\hline Biopolymers & Plasticizer & Crosslinking Agent & Changes in Properties & Reference \\
\hline \multicolumn{5}{|c|}{ Starch } \\
\hline $\begin{array}{c}\text { Cassava and rice } \\
\text { starch/maltodextrin/agar }\end{array}$ & Glycerin & - & $\begin{array}{l}\text { High film forming ability for package molding, improved the mechanical and water } \\
\text { barrier properties, decreased relaxation temperatures, improved water sensitivity. }\end{array}$ & [242] \\
\hline $\begin{array}{l}\text { Potato starch/cellulose fibers from } \\
\text { sunflower husk }\end{array}$ & Glycerin & Citric acid & $\begin{array}{l}\text { Improved resistance towards stress and sufficient extensibility and high tensile } \\
\text { strength, brittleness due to starch-cellulose interactions and decreased starch chain } \\
\text { mobility, reinforced network and decreased in swelling. }\end{array}$ & [279] \\
\hline Tapioca starch/beeswax/propolis & Glycerin & - & $\begin{array}{l}\text { Lower values of water vapor permeability and water solubility; decreased in the } \\
\text { moisture content and vapor water permeability. }\end{array}$ & [458] \\
\hline Rice starch/cellulose fiber mesocarp & - & - & Enhanced thermal stability and lowered water uptake & [459] \\
\hline Rice starch/cellulose & Glycerin/sorbitol & - & $\begin{array}{c}\text { Reinforced mechanically the films (higher tensile strength) and reduced water vapor } \\
\text { permeabilities }\end{array}$ & {$[460]$} \\
\hline $\begin{array}{l}\text { Pea starch/CMC and pea } \\
\text { starch/MC }\end{array}$ & Glycerin & - & $\begin{array}{l}\text { Improved the storage modulus and the glass transition temperature, increased the } \\
\text { tensile stress, elongation at break and the barrier of water vapor; MC increased the } \\
\text { thermalstability, while CMC decreased the thermal stability. }\end{array}$ & [461] \\
\hline Turmeric starch/gelatin & Glycerin & & Gelatin increased flexibility and elongation at break & [462] \\
\hline \multicolumn{5}{|c|}{ Cellulose and derivatives } \\
\hline Wood cellulose/sodium alginate & - & Calcium chloride & $\begin{array}{l}\text { Increased the mechanical properties (tensile), improved grease barrier properties and } \\
\text { reduced water vapor permeability }\end{array}$ & [463] \\
\hline Cellulose/collagen hydrolysate & - & - & $\begin{array}{l}\text { Exhibited good transparence and the capacity for ultraviolet radiation absorption, } \\
\text { improved the mechanical properties and enhanced the stability in distilled water. }\end{array}$ & [464] \\
\hline Cellulose/chitosan & - & - & $\begin{array}{l}\text { High transparent property, excellent barrier properties against oxygen and } \\
\text { antimicrobial properties. }\end{array}$ & [465] \\
\hline \multicolumn{5}{|c|}{ Pectin } \\
\hline $\begin{array}{l}\text { Fruit and vegetable wastes (fruit } \\
\text { and vegetable flour) }\end{array}$ & - & - & $\begin{array}{l}\text { Decreased solubility (50\%) and improved of the mechanical properties (decrease of } \\
\text { elongation and increase of tensile strength) }\end{array}$ & {$[466]$} \\
\hline Citrus pectin/sodium alginate & Polyglycerin & Zinc chloride & Improved the strength of crosslinking network, improved mechanical performance. & [467] \\
\hline Papaya puree/alginate & Glycerin & $\begin{array}{l}\text { Calcium chloride/citric } \\
\text { acid }\end{array}$ & Improved puncture strength & [357] \\
\hline Pectin/protein phaseolin & - & $\begin{array}{l}\text { Microbial } \\
\text { transglutaminase }\end{array}$ & $\begin{array}{l}\text { Mechanical properties and barrier properties to } \mathrm{CO}_{2}, \mathrm{O}_{2} \text { and water vapor was } \\
\text { comparable to commercial plastics. }\end{array}$ & [468] \\
\hline
\end{tabular}


Table 2. Cont

\begin{tabular}{|c|c|c|c|c|}
\hline Biopolymers & Plasticizer & Crosslinking Agent & Changes in Properties & Reference \\
\hline \multicolumn{5}{|c|}{ Chitosan } \\
\hline Chitosan/collagen & Glycerin & - & $\begin{array}{l}\text { Displayed higher elongation at break point, but lower tensile strength and modulus of } \\
\text { elasticity, increased water vapor permeability, decreased transparency }\end{array}$ & [469] \\
\hline Quaternized chitosan/CMC & - & - & $\begin{array}{c}\text { Improved tensile properties, thermostability, oxygen permeability values, and water } \\
\text { resistance }\end{array}$ & {$[470]$} \\
\hline \multicolumn{5}{|c|}{ Alginate } \\
\hline Alginate/pectin & Glycerin & Calcium chloride & $\begin{array}{l}\text { Continuous, homogenous and transparent films, chemical composition influenced on } \\
\text { color, water vapor permeability, tensile strength, elongation at break }\end{array}$ & [471] \\
\hline Alginate/gum & - & Calcium chloride & Improved the strength of network & [472] \\
\hline Alginate/cotton hydrolysate & Glycerin & - & $\begin{array}{l}\text { Increased the barrier properties to visible light, did not affect the moisture content, } \\
\text { biodegradability, solubility or oil barrier properties, increased the thickness and water } \\
\text { vapor permeability }\end{array}$ & [473] \\
\hline Alginate/chitosan & Glycerin & Calcium chloride & $\begin{array}{l}\text { Decreased water solubility, but increased film thickness, water vapor permeability and } \\
\text { oxygen permeability, good barrier properties against ultraviolet light. }\end{array}$ & [474] \\
\hline \multicolumn{5}{|c|}{ Casein } \\
\hline $\begin{array}{l}\text { Lactic acid casein powder/carnauba } \\
\text { or candelilla waxes }\end{array}$ & Sorbitol & - & Decreased water permeability & [475] \\
\hline Casein/cellulose microgel & - & - & $\begin{array}{l}\text { Reduced the moisture absorption and the water vapor permeability, homogeneous } \\
\text { and dense cross-sectional structure, increased the cleavage temperature, tensile } \\
\text { strength and Young's modulus }\end{array}$ & [476] \\
\hline $\begin{array}{c}\text { Sodium } \\
\text { caseinate/low-methoxylated pectin }\end{array}$ & - & - & $\begin{array}{l}\text { Increased the stiffness of films (Young's modulus) and decreased flexibility, decreased } \\
\text { water content }\end{array}$ & [477] \\
\hline \multicolumn{5}{|c|}{ Collagen } \\
\hline Fish skin collagen/chitosan & - & - & Lowered water solubility and lightness & [478] \\
\hline Cattle skin collagen/HPMC & PEG 1500 & - & $\begin{array}{l}\text { Elevated thermal decomposition temperature and denaturation temperature, } \\
\text { exhibited a more homogeneous and compact structure, improved tensile strength, } \\
\text { ultimate elongation, hydrophilicity, stretch-ability and smoothness }\end{array}$ & [479] \\
\hline Collagen/galactomannan & Glycerin & - & Convenient values of wettability & [480] \\
\hline
\end{tabular}


Table 2. Cont

\begin{tabular}{|c|c|c|c|c|}
\hline Biopolymers & Plasticizer & Crosslinking Agent & Changes in Properties & Reference \\
\hline & & $\mathrm{Ge}$ & & \\
\hline Gelatin/chitosan & Glycerin & - & \multirow{2}{*}{$\begin{array}{c}\text { No significant difference in tensile strength, thickness and transparency } \\
\text { Increased tensile strength, elongation to break, elastic modulus and swelling property, } \\
\text { more transparent, and easier to handle }\end{array}$} & {$[481,482]$} \\
\hline $\begin{array}{l}\text { Soy protein isolate/bovine bone } \\
\text { gelatin }\end{array}$ & Glycerin & - & & [483] \\
\hline $\begin{array}{l}\text { Whey protein } \\
\text { isolate/gelatin/sodium alginate }\end{array}$ & Glycerin & - & Improved barrier to oxygen, water vapor and mechanical properties & {$[484]$} \\
\hline Fish gelatin/CMC & Glycerin/sorbitol & - & $\begin{array}{c}\text { Increased tensile strength and Young's modulus, decreased the elongation percent and } \\
\text { equilibrium moisture }\end{array}$ & {$[485]$} \\
\hline
\end{tabular}


The knowledge of the nature, structure, and properties of biopolymers allows compositions to be combined for producing films and coatings with improved properties [23]. Composite materials are obtained in the form of a multilayer structure by alternating hydrophilic and hydrophobic layers, or in the form of single-layer films with a multicomponent composition [486].

\subsection{Safety Requirements for Components of Edible Films}

Materials in contact with food containing food additives, ingredients, and agents should not have a negative impact on the properties of the product and must meet current hygienic requirements [487]. Nowadays, there are no relevant legislative documents for biopolymer films and coatings, so manufacturers are guided by regulatory documents related to polymer materials in contact with food products [441].

In accordance with current manufacturing practices, edible packaging materials must have a permit from the Food and Drug Administration (FDA), after which they are usually qualified as Generally Recognized as Safe (GRAS) products [488]. GRAS materials can be used in edible films and coatings within the limits set by the FDA [489]. If the material does not qualify for GRAS, the manufacturer may apply for a safety confirmation of the component used or use it without approval, which applies to materials that received "prior approval" or were entered before 1958 in the FDA register [490]. The main risk for the use of components is the possible migration of substances from the packaging to the food [441].

Except for chitosan, polysaccharides, including cellulose and its derivatives (CMC, MC, HPMC), starches and its derivatives, pectins, and seaweed extracts (agar, alginates, carrageenan), are either approved food additives or GRAS substances [388]. The most commonly used proteins, such as corn zein, wheat gluten, soy protein and milk proteins, some types of collagen, and gelatin have GRAS status [491]. However, there are some concerns about possible allergenicity or intolerance of wheat or milk proteins for some consumers [492].

Edible food films and coatings are also biodegradable, which implies their complete decomposition by microorganisms during the composting process to products that do not harm the environment [492]. The problem with biodegradable films and coatings is that they must perform their functions safely and effectively for a certain period of time, and only then must they undergo a decomposition stage [490].

\section{Methods for Estimating Edible Films Quality}

Edible films are considered a special type of packaging material that can be eaten together with the product [237]. Such types of biopolymers as proteins, polysaccharides and lipids, as well as their various combinations, are used for edible films production [493]. The composition and structure of biopolymer films, as well as the introduction of various functional components, have a significant impact on the properties of the obtained material. In this regard, there is an obvious need for a comprehensive assessment of the properties of the developed film materials for their further targeted application. The main parameters include mechanical, barrier, optical, hydratative, and microstructural parameters [494]. A comprehensive study of the listed characteristics of the films is possible due to the use of modern research methods discussed in this section.

\subsection{Basic Requirements for Testing the Condition of Films}

Most researchers rely on the requirements of existing regulatory documents developed for synthetic polymer materials when studying the properties of biopolymer films. In this case, it is possible to adapt standardized methods depending on the equipment and the specific test conditions in a certain laboratory.

Special attention should be paid to maintaining the same conditions before and during the testing of films in order to achieve comparability and reliability of the obtained results. The ASTM D882-10 standard establishes the recommended sample preparation requirements for the following parameters: temperature $23 \pm 2{ }^{\circ} \mathrm{C}$ and a relative humidity 
of $50 \pm 10 \%$ for $40 \mathrm{~h}$ [495]. Previously, the films are placed in a desiccator containing a saturated solution of magnesium chloride $\mathrm{MgCl}_{2}$ [29], magnesium nitrate $\left(\mathrm{Mg}\left(\mathrm{NO}_{3}\right)_{2}\right)$ [496], or sodium bromide (NaBr) [452], etc. Conditioning is necessary, since most edible materials tend to absorb excess moisture, which can lead to changes in the mechanical, physicochemical, and hydration properties of the films [497].

An important parameter for testing is the precise determination of the thickness of the material, since some properties, such as mechanical or physico-chemical, depend significantly on this indicator. The film thickness is measured with a manual digital or mechanical micrometer with an accuracy of $0.001 \mathrm{~mm}$ in several repetitions, choosing arbitrary points in the center and around the perimeter [29]. The average value of the obtained results is taken as the film thickness.

\subsection{Mechanical Properties}

The mechanical strength of the edible film is one of the most important characteristics that allow the limit of the material's resistance to physical destruction to be determined. The value of the mechanical strength indirectly indicates the degree of food product protection from physical and chemical impacts [498].

The determination of mechanical properties includes investigation of such indicators as tensile strength (TS), elongation at break (EB), elastic modulus (EM), and puncture force (PF). The tensile strength, elongation to break, and elastic modulus are the most common parameters used to evaluate mechanical properties [499].

The determination of TS and EB is carried out according to standards ASTM D88210 and ISO 527-1:2019 [495,500]. Universal breaking machines or texture analyzers are usually used for testing edible films and providing a constant rate of force increase with a relative error of the breaking force of $\pm 1.0 \%$ and an absolute error of the elongation of $\pm 1.0 \mathrm{~mm}$ [495].

The equipment must be fitted with tension clamps, which may be metal or in the form of sponges [401]. The use of cardboard gaskets to avoid slipping and cracking of the film in the clamps is allowed [501]. The ends of the gaskets must be at the level of the clamping planes, which limit the clamping length of the sample.

After conditioning, rectangular strips of a certain standard length and width are cut out from each film sample using a scissor [29], scalpel [502], blade [501], or guillotine [503]. According to the standard, the nominal width of the test samples is not less than $5.0 \mathrm{~mm}$ and not more than $25.4 \mathrm{~mm}$ [495]. The prepared samples must be free of visible damage, tears, and notches at the edges. The film is fixed in a strictly vertical position in the clamps with a set distance. The pre-force value is selected depending on the thickness (structure) of the films. The initial distance between the clamps and the required speed of the crosshead are set before testing. A breaking machine or texture analyzer records values using an appropriate software [504].

Tensile strength (TS, MPa) is calculated by dividing the maximum force on the initial cross section of the sample using the equation [505]:

$$
\mathrm{TS}=\mathrm{Fmax} / \mathrm{A}
$$

where Fmax is the maximum force $(\mathrm{H})$ and $\mathrm{A}$ is the sample cross-sectional square $\left(\mathrm{m}^{2}\right)$.

Elongation at break $(\mathrm{E}, \%)$ is calculated using the equation [506]:

$$
\mathrm{E}=(\mathrm{b} / \mathrm{a}) \times 100
$$

where $b$ is the sample length during deformation $(\mathrm{mm})$ and $a$ is the initial sample length $(\mathrm{mm})$.

The calculation of the obtained data is carried out to the first decimal place, followed by rounding to an integer. The measurements are repeated at least 5 times, and the arithmetic mean value is calculated.

Elastic modulus (EM) is the characteristic of film rigidity. The equipment and the method of preparing films for testing are similar to the determination of tensile strength 
and elongation at break [507]. The elastic modulus is determined by the ratio of the normal force to the corresponding deformation within the limits of proportionality [508].

The EM (MPa) could be determined according to the angle of the curve tensiondeformation using the equation [509]:

$$
\mathrm{EM}=\sigma_{\mathrm{T}} /\left(\varepsilon_{\mathrm{T}} \times \exp \left(-\varepsilon_{\mathrm{T}} * \mathrm{k}\right)\right)
$$

where $\varepsilon_{\mathrm{T}}$ and $\sigma_{\mathrm{T}}$ are the deformation and tension, respectively, and $\mathrm{k}$ is a constant coefficient.

Puncture force determines the resistance of the material to dynamic puncture and the spread of tear when making a puncture. The measurement of this indicator is carried out according to ASTM D6241-14 standard [510].

Studies of films are carried out on testing machines, for example, texture analyzers, equipped with special nozzles designed to measure the resistance to puncture. The film samples are pre-condensed before testing. Films of a certain shape and size, for example, 30 $\mathrm{mm} \times 30 \mathrm{~mm}$, are placed on the support ring of the texture analyzer. The round aluminum plate is fixed with screws to prevent the films from slipping off. Then, a spherical stainlesssteel probe of a certain diameter is brought perpendicular to the surface of the film at a constant speed of $1 \mathrm{~mm} / \mathrm{s}$ until it punctures the sample. The puncture force coefficient is obtained from the "force-deformation" curves recorded using the software [496]. Puncture deformation $(\mathrm{PD}, \%)$ is calculated using the equation [511]:

$$
\mathrm{PD}=\left(\sqrt{ }\left(\mathrm{D} 2-\mathrm{l}_{\mathrm{o}} 2-\mathrm{l}_{\mathrm{o}}\right) / \mathrm{l}_{\mathrm{o}}\right) \times 100
$$

where $l_{\mathrm{o}}$ is the initial length of the film, equal to the radius of the annular space $(\mathrm{mm})$ and $\mathrm{D}$ is the displacement of the probe at the rupture point $(\mathrm{mm})$.

\subsection{Physico-Chemical Properties}

The study of physio-chemical characteristics is carried out in order to determine the barrier properties of edible films, which allow the level of permeability of biopolymer films in relation to water vapor and various gases, such as $\mathrm{O}_{2}$ and $\mathrm{CO}_{2}$, to be assessed. Permeability is one of the most important transport properties of films and coatings, and depends on both biopolymer nature and such properties, as roughness, porosity, arrangements of unidirectionally aligned fibers, area fractal dimension of pore and tortuosity fractal dimension. Factors such as the temperature or presence of electrolytes could also influence on permeability. Some theoretical models were developed to predict the transverse permeability depending on square, staggered, and hexagonal arrangements of fibers. Moreover, permeability can be expressed as a function of the unit cell aspect ratio, porosity, fiber size, net charge density, and viscosity and electrical conductivity of the electrolyte solution [512,513]. Nevertheless, permeability of films is usually evaluated by standard methods, described in ASTM E96 and ASTM D3985 [514,515].

\subsubsection{Water Vapor Permeability}

Water vapor permeability (WVP) is determined by the gravimetric method according to the ASTM E96 [514]. The method is based on the dependence of the change in the mass of the test sample on time. A weighing bottle with a certain depth and diameter with a screw or conventional lid is used for measuring WVP. The film sample is placed on top of the weighing bottle and fixed with a lid with a rubber O-ring [496].

There are two main ways of determining WVP. The most common method is the dry method, which is based on the transition of water vapor through the sample from moist air into a space with a desiccant (silica gel) where the humidity is close to zero [29].

According to the second way (wet method), water vapor from a cup of water, where the air humidity is close to $100 \%$, passes through the sample into air having a lower humidity (about $30 \%$ ). In this case, the samples are placed in ventilated chambers, providing a gradient of relative humidity between the two sides of the film at a level of $30-100 \%$ [471]. 
Water vapor permeability (WVP, $\left.\mathrm{g} \cdot \mathrm{m} / \mathrm{m}^{2} \cdot \mathrm{s} \cdot \mathrm{Pa}\right)$ is calculated using the equation [29]:

$$
\mathrm{WVR}=(\Delta \mathrm{m} \times \mathrm{e}) /(\mathrm{A} \times \Delta \mathrm{t} \times \Delta \mathrm{p})
$$

where $\Delta \mathrm{m} / \Delta \mathrm{t}$ is the mass of lost moisture per unit of time $\left(\mathrm{g} \cdot \mathrm{s}^{-1}\right), \mathrm{A}$ is the square of the film subject to moisture transfer $\left(\mathrm{m}^{2}\right)$, e is the film thickness $(\mathrm{m})$, and $\Delta \mathrm{p}$ is the pressure change of water vapor between the two sides of the film $(\mathrm{Pa})$.

\subsubsection{Gaseous Permeability}

Gas permeability is an important property of biopolymer materials since each type of biopolymer has a different degree of gas permeability [516]. Oxygen and carbon dioxide have a great influence on the quality and safety of products during storage; therefore, the determination of gas permeability of films requires special attention [517].

The measurement of the gas permeability of the films is carried out according to the ASTM D3985 standard [515]. The test is performed on an appropriate equipment: a tester [518] or an oxygen permeability analyzer [519]. Films were cut into $4 \mathrm{~cm}$ diameter and covered with aluminum foil on both sides in order to avoid contact of the test gas with other areas of the film. An uncovered space in the form of a circle was left for the equipment cell [520]. During the test, the prepared film sample is placed in the cell of the analyzer or tester, where the film is isolated on both sides. Oxygen or carbon dioxide is supplied on one side, and a neutral gas consisting of $98 \%$ nitrogen and $2 \%$ hydrogen on the other [519].

Gas permeability against oxygen or carbon dioxide of films ( $\mathrm{OP}$ or $\mathrm{CP}, \mathrm{cm}^{3} / \mathrm{m} \cdot \mathrm{Pa}$ ) is calculated using the equation [519]:

$$
\mathrm{OP}=(\mathrm{OTR} \times \mathrm{A}) / \Delta \mathrm{p}
$$

where OTR is the gas transmission rate $\left(\mathrm{cm}^{3} / \mathrm{m}^{2}\right)$, A is the film thickness $(\mathrm{m})$, and $\Delta \mathrm{p}$ is the partial pressure difference between the film sides $(\mathrm{Pa})$.

\subsection{Hydration Properties}

Different hydrocolloids are obtained from different natural sources of animal and plant origin, so the films based on them have different levels of solubility. Obviously, films prepared from proteins biopolymers (sodium caseinate, whey protein isolate, gelatin) and plant polysaccharides (CMC, sodium alginate, and potato starch) demonstrated different hydration properties [521,522]. The solubility of edible films is a key parameter for assessing their resistance to solvents, such as water, acid, and alkali [523].

\subsubsection{Films Solubility}

Most biopolymer films based on protein and polysaccharides without the introduction of crosslinking agents and/or tanning agents have a high solubility in water [523]. In many studies, the solubility of films is determined according to the method proposed by Gontard and Guilbert [523]. The film samples are ground into small rectangular pieces and dried at a temperature of $100{ }^{\circ} \mathrm{C}$ for $24 \mathrm{~h}$ to a constant mass. The samples are then placed in $100 \mathrm{~mL}$ of distilled water, and either hydrochloric acid ( $\mathrm{pH} 4.0)$ or sodium hydroxide ( $\mathrm{pH} 10.0)$, for $24 \mathrm{~h}$. Next, the films are removed from the solutions and re-dried at $100{ }^{\circ} \mathrm{C}$ for $24 \mathrm{~h}$, and the final mass is fixed.

The approach described by Gontard et al. [524] is used as an alternative method. The film samples are cut into square pieces $(2 \mathrm{~cm} \times 2 \mathrm{~cm})$, and weighed and dried in a drying cabinet at a temperature of $105^{\circ} \mathrm{C}$ for $12 \mathrm{~h}$. Then, the dry films are re-weighed to determine the initial mass. The film samples are placed in $30 \mathrm{~mL}$ of solvent at a temperature of $25^{\circ} \mathrm{C}$ and kept at room temperature for $24 \mathrm{~h}$. The remaining parts of the undissolved film are removed and dried at $105^{\circ} \mathrm{C}$ for $24 \mathrm{~h}$ and weighed to determine the final mass. 
Films solubility (FS, \%) is calculated using the equation [520]:

$$
\mathrm{FS}=\left(\mathrm{W}_{\mathrm{i}}-\mathrm{W}_{\gamma}\right) / \mathrm{W}_{\mathrm{i}} \times 100
$$

where $\mathrm{W}_{\mathrm{i}}$ is the initial dry film weight $(\mathrm{g})$ and $\mathrm{W}_{\gamma}$ is the final dry film weight $(\mathrm{g})$.

\subsubsection{Swelling Index}

The swelling index allows the level of moisture absorption (absorption capacity) of the edible film to be evaluated. This parameter has a high correlation with solubility [525] and the structure density and thickness of edible films [29], as well as with hydrophilicity of biopolymers used for films processing.

According to the method by Basiak et al. (2017), the film samples are cut into $2 \mathrm{~cm} \times 2 \mathrm{~cm}$ pieces and weighed and immersed in distilled water $\left(25^{\circ} \mathrm{C}\right)$ for $2 \mathrm{~min}$. Wet samples are blotted with filter paper to remove excess liquid and weighed. A similar Equation (7) is used to determine the swelling index [29].

\subsubsection{Contact Angle Measurements}

A contact angle measurement allows the level of film hydrophobicity to be determined and is based on the sessile-drop technique. The sessile-drop contact angle $(\theta)$ is formed due to the interfacial tension, and the vertex of the angle lies at the interface of three phases: $\gamma_{\mathrm{sv}}$ (solid-vapor), $\gamma_{\mathrm{lv}}$ (liquid-vapor), and $\gamma_{\mathrm{sl}}$ (solid-liquid) [499]. The schematic of a sessile-drop contact angle system is presented in Figure 16. The measurement of the sessile-drop contact angle is carried out by determining the tangent (angle) of the liquid drop to the solid surface at the base [526].

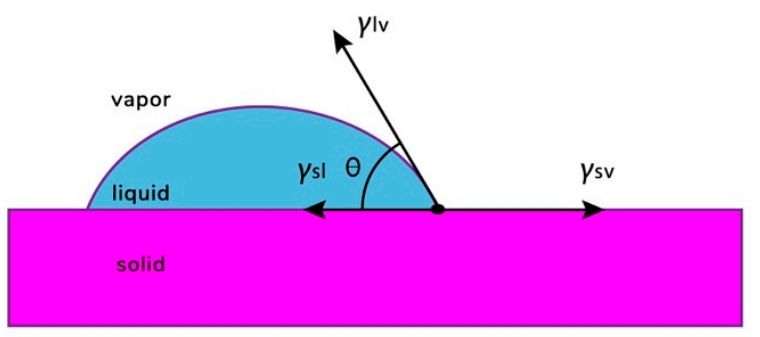

Figure 16. Schematic of a sessile-drop contact angle system [526]. Reproduced with permission from Kwok, D.Y. and Neumann, A.W., Advances in Colloid and Interface Science; Elsevier Science B.V., 1999.

A standard liquid is used for the test, for example, glycerin. There are restrictions on the use of water as a standard liquid since food films have high hydrophilic properties, which lead to their rapid swelling [527]. A drop of 1.5-2.0 $\mu \mathrm{L}$ of the test liquid is applied to the horizontal surface of the film, which was in contact with the air at the time of drying [528]. The sessile-drop contact angle is measured on one or both sides of the drop using a digital microscope equipped with image analysis software [499]. The image of the edge angle is taken immediately, within $60 \mathrm{~s}$ after touching the liquid on the surface of the film, in order to avoid evaporation, dissolution, and swelling processes [528].

The obtained results allow the relationship between the surface tension energies of the three phases to be described, according to the Young equation [529]:

$$
\gamma \mathrm{lv} \cos \gamma \theta \mathrm{Y}=\gamma \mathrm{sv}-\gamma \mathrm{sl}
$$

where $\gamma_{\mathrm{lv}}$ is the interfacial boundary tension: liquid-gas, $\gamma_{\mathrm{sv}}$ is the interfacial boundary tension: solid-gas, $\gamma_{\mathrm{sl}}$ is the interfacial boundary tension: solid-liquid, and $\mathrm{Y}$ is the Young's edge angle. 


\subsection{Scanning Electron Microscopy}

Scanning electron microscopy (SEM) is performed to determine the morphological features of the surface and cross-section of edible films. The study of the microstructure of films allows an expanded understanding of the influence of modifiers on the processes of structure formation to be obtained, with the identification of cracks, porosity, roughness, uniformity, and density of the material structure (Figure 17).

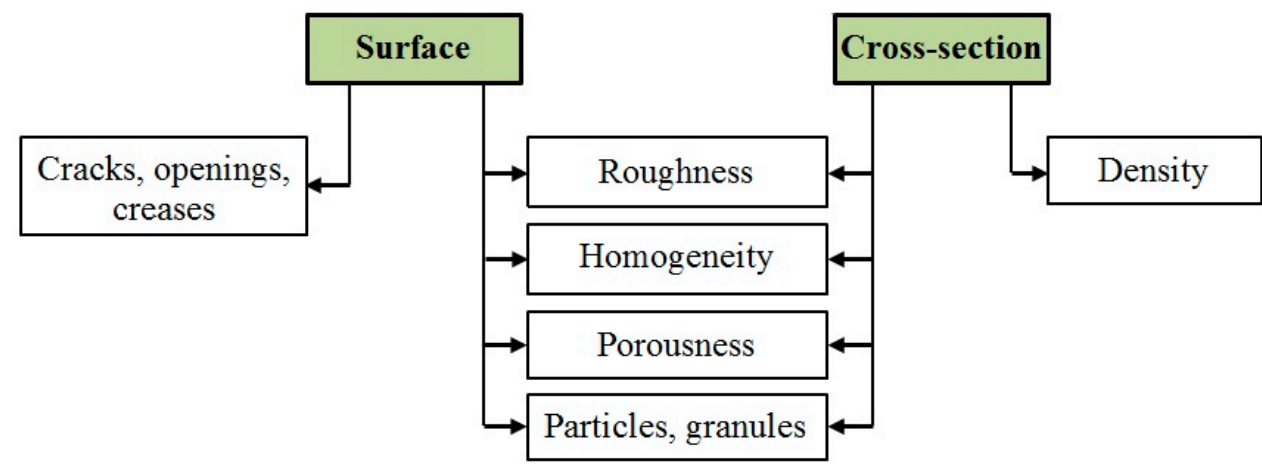

Figure 17. Characteristics of the film structure determined by SEM.

There is a direct relationship between the structure and the mechanical, physicochemical, and hydration properties of the films. SEM is recommended for composite films, for example, alginate/pectin [467], nanoemulsions [496], or when introducing functional additives, such as essential oils [530] or nanoparticles [531].

The microstructure of the films is studied using a scanning electron microscope. The films are pre-frozen in liquid nitrogen and randomly destroyed for the assessment of crosssection morphology. The films are treated with carbon, placed on an aluminum holder, and fixed to the support with double-sided tape. Gold or gold-palladium is applied to the surface of the samples for making electroconductive properties (visualization), and the samples are observed at an accelerating voltage of 5 to $15 \mathrm{kV}$ and an operating distance of $10 \mathrm{~mm}[29]$.

\section{Conclusions and Future Perspectives}

Traditional plastics do not degrade and accumulate in large quantities, which cause significant harm to the environment. The development and application of bioactive packaging systems from environmentally friendly biopolymers is a relevant field of research.

Animal proteins and natural polysaccharides are the most common biopolymers for the production of edible films and coatings. Nevertheless, such biopolymers have a list of limitations for this application mainly due to its structure and properties, such us brittleness and unsufficient mechanical properties, as well as high hidrophilicity cased low water stability, high moisture sensitivity and water vapor permeability. These disadvantages could be overcome by blending and composite films production, implementation of crosslinking agents and plasticizers, as well as the application of appropriate ways of film production based on the biopolymer structure and type of food product. Novel edible films must meet the requirements of quality and safety.

We made an effort to summarize information about such popular biopolymers from renewable resources as starch, cellulose, pectin, chitosan, alginate, casein, collagen and gelatin, discuss the main advantages and disadvantages, approaches for properties improving, recommended film-forming solution, appropriate form and ways of production of films and coatings, as well as type of packaged food based on the compatibility and nature of a certain biopolymer. Moreover, approaches for films and coating production were also reviewed as in general so and for certain type of biopolymers. We also collected usual methods for assessment the properties of designed films. This information allows the reader to make the first insight into environmentally friendly packaging from nature of polimer till properties of packaging material. 
Nevertheless, films based on one biopolymer could be not so competitive to traditional plastics. In this regard, blending and composite materials are particularly relevant, because combination of biopolymers and its modificated derivates could allow create packaging material with properties of plastics without microplastic addition. On the other hand, created new composites should be more deeply studied, because of containing two or more biopolymer chaines. In this regard, additional investigation approaches, such as scanning electron microscopy, could clear the interoperability of biopolymers. Scanning electron microscopy is also essential for investigation of films with introduced functional additives, which are widely used for improving the biological properties of packaging matherials.

Global ecologization dictates its own conditions to the manufacturer; consumer acceptance is also driven in biodegradability and eco-friendliness. Nowadays, due to the efforts of scientists worldwide, the creation of competitively packaging material based on biopolymers is a reality, but not a myth.

Author Contributions: Conceptualization, V.N. and E.K.; data curation, V.N. and E.K.; writingoriginal draft preparation, E.P. (Section 2), I.K. (Section 3) and N.R. (Section 4); writing-review and editing, E.K.; visualization, E.P., I.K., E.K. and N.R.; supervision, E.K. and A.S.; project administration, A.L. and A.S.; funding acquisition, A.L. and A.S. All authors have read and agreed to the published version of the manuscript.

Funding: This work was supported by a grant of the Ministry of Science and Higher Education of the Russian Federation for large scientific projects in priority areas of scientific and technological development (Grant No.075-15-2020-775).

Institutional Review Board Statement: Not applicable.

Informed Consent Statement: Not applicable.

Data Availability Statement: Data sharing not applicable.

Acknowledgments: Authors would like to thank Yana Uglitskikh for graphical and artwork https: //www.behance.net/yanzaugb68e (accessed on 13 May 2021).

Conflicts of Interest: Authors declare no conflict of interest.

\section{References}

1. Wohner, B.; Pauer, E.; Heinrich, V.; Tacker, M. Packaging-Related Food Losses and Waste: An Overview of Drivers and Issues. Sustainability 2019, 11, 264. [CrossRef]

2. Arkoun, M.; Daigle, F.; Holley, R.A.; Heuzey, M.C.; Ajji, A. Chitosan-based nanofibers as bioactive meat packaging materials. Packag. Technol. Sci. 2018, 31, 185-195. [CrossRef]

3. Moreira, D.; Gullón, B.; Gullón, P.; Gomes, A.; Tavaria, F. Bioactive packaging using antioxidant extracts for the prevention of microbial food-spoilage. Food Funct. 2016, 7, 3273-3282. [CrossRef]

4. Garavand, F.; Rouhi, M.; Razavi, S.H.; Cacciotti, I.; Mohammadi, R. Improving the integrity of natural biopolymer films used in food packaging by crosslinking approach: A review. Int. J. Biol. Macromol. 2017, 104, 687-707. [CrossRef]

5. Iwata, T. Biodegradable and Bio-Based Polymers: Future Prospects of Eco-Friendly Plastics. Angew. Chem. Int. Ed. 2015, 54, 3210-3215. [CrossRef]

6. Kabir, E.; Kaur, R.; Lee, J.; Kim, K.-H.; Kwon, E.E. Prospects of biopolymer technology as an alternative option for non-degradable plastics and sustainable management of plastic wastes. J. Clean. Prod. 2020, 258, 120536. [CrossRef]

7. Datta, J.; Kopczyńska, P. From polymer waste to potential main industrial products: Actual state of recycling and recovering. Crit. Rev. Environ. Sci. Technol. 2016, 46, 905-946. [CrossRef]

8. Faraca, G.; Astrup, T. Plastic waste from recycling centres: Characterisation and evaluation of plastic recyclability. Waste Manag. 2019, 95, 388-398. [CrossRef] [PubMed]

9. Miandad, R.; Barakat, M.A.; Aburiazaiza, A.S.; Rehan, M.; Nizami, A.S. Catalytic pyrolysis of plastic waste: A review. Process Saf. Environ. Prot. 2016, 102, 822-838. [CrossRef]

10. Mwanza, B.G.; Mbohwa, C. Drivers to Sustainable Plastic Solid Waste Recycling: A Review. Procedia Manuf. 2017, 8, 649-656. [CrossRef]

11. Ragaert, K.; Delva, L.; Van Geem, K. Mechanical and chemical recycling of solid plastic waste. Waste Manag. 2017, 69, 24-58. [CrossRef] [PubMed]

12. Wróblewska-Krepsztul, J.; Rydzkowski, T. Pyrolysis and incineration in polymer waste management system. J. Mech. Energy Eng. 2020, 3, 337-342. [CrossRef]

13. Jakobek, L. Food packaging materials with polyphenols as active compounds. Meso 2019, 21, 469-474. [CrossRef] 
14. Stoica, M.; Marian Antohi, V.; Laura Zlati, M.; Stoica, D. The financial impact of replacing plastic packaging by biodegradable biopolymers-A smart solution for the food industry. J. Clean. Prod. 2020, 277, 124013. [CrossRef]

15. Popović, S.Z.; Lazić, V.L.; Hromiš, N.M.; Šuput, D.Z.; Bulut, S.N. Chapter 8-Biopolymer Packaging Materials for Food Shelf-Life Prolongation. In Biopolymers for Food Design, 1st ed.; Grumezescu, A.M., Holban, A.M., Eds.; Academic Press: Cambridge, MA, USA, 2018; Volume 10, pp. 223-277. [CrossRef]

16. Gómez-Estaca, J.; Gavara, R.; Catalá, R.; Hernández-Muñoz, P. The Potential of Proteins for Producing Food Packaging Materials: A Review. Packag. Technol. Sci. 2016, 29, 203-224. [CrossRef]

17. Nechita, P.; Roman (Iana-Roman), M. Review on Polysaccharides Used in Coatings for Food Packaging Papers. Coatings 2020, 10, 566. [CrossRef]

18. Weber, C.J.; Haugaard, V.; Festersen, R.; Bertelsen, G. Production and applications of biobased packaging materials for the food industry. Food Addit. Contam. 2002, 19, 172-177. [CrossRef]

19. Yadav, A.; Mangaraj, S.; Singh, R.; Das, K.; Kumar, N.; Arora, S. Biopolymers as packaging material in food and allied industry. Int. J. Chem. Stud. 2018, 6, 2411-2418.

20. Adeyeye, O.A.; Sadiku, E.R.; Babu Reddy, A.; Ndamase, A.S.; Makgatho, G.; Sellamuthu, P.S.; Perumal, A.B.; Nambiar, R.B.; Fasiku, V.O.; Ibrahim, I.D.; et al. The Use of Biopolymers in Food Packaging. In Green Biopolymers and their Nanocomposites. Materials Horizons: From Nature to Nanomaterials, 1st ed.; Gnanasekaran, D., Ed.; Springer: Singapore, 2019; pp. 137-158. [CrossRef]

21. Srivastava, P.; Bano, K.; Zaheer, M.R.; Kuddus, M. Biodegradable Smart Biopolymers for Food Packaging: Sustainable Approach Toward Green Environment. In Bio-Based Materials for Food Packaging, 1st ed.; Ahmed, S., Ed.; Springer: Singapore, 2018; pp. 197-216. [CrossRef]

22. Xu, T.; Ma, C.; Aytac, Z.; Hu, X.; Ng, K.W.; White, J.C.; Demokritou, P. Enhancing Agrichemical Delivery and Seedling Development with Biodegradable, Tunable, Biopolymer-Based Nanofiber Seed Coatings. ACS Sustain. Chem. Eng. 2020, 8 , 9537-9548. [CrossRef]

23. Dhumal, C.V.; Sarkar, P. Composite edible films and coatings from food-grade biopolymers. J. Food Sci. Technol. 2018, 55, 4369-4383. [CrossRef] [PubMed]

24. Ghanbarzadeh, B.; Oleyaei, S.A.; Almasi, H. Nanostructured Materials Utilized in Biopolymer-based Plastics for Food Packaging Applications. Crit. Rev. Food Sci. Nutr. 2015, 55, 1699-1723. [CrossRef] [PubMed]

25. Wicochea-Rodríguez, J.D.; Chalier, P.; Ruiz, T.; Gastaldi, E. Active Food Packaging Based on Biopolymers and Aroma Compounds: How to Design and Control the Release. Front. Chem. 2019, 7, 398. [CrossRef]

26. Cazón, P.; Velazquez, G.; Ramírez, J.A.; Vázquez, M. Polysaccharide-based films and coatings for food packaging: A review. Food Hydrocoll. 2017, 68, 136-148. [CrossRef]

27. Mohamed, S.A.A.; El-Sakhawy, M.; El-Sakhawy, M.A.-M. Polysaccharides, Protein and Lipid -Based Natural Edible Films in Food Packaging: A Review. Carbohydr. Polym. 2020, 238, 116178. [CrossRef]

28. Thakur, R.; Pristijono, P.; Scarlett, C.J.; Bowyer, M.; Singh, S.P.; Vuong, Q.V. Starch-based films: Major factors affecting their properties. Int. J. Biol. Macromol. 2019, 132, 1079-1089. [CrossRef] [PubMed]

29. Basiak, E.; Lenart, A.; Debeaufort, F. Effect of starch type on the physico-chemical properties of edible films. Int. J. Biol. Macromol. 2017, 98, 348-356. [CrossRef] [PubMed]

30. Kadokawa, J.-i. Preparation and Applications of Amylose Supramolecules by Means of Phosphorylase-Catalyzed Enzymatic Polymerization. Polymers 2012, 4, 116-133. [CrossRef]

31. Lemos, P.V.F.; Barbosa, L.S.; Ramos, I.G.; Coelho, R.E.; Druzian, J.I. Characterization of amylose and amylopectin fractions separated from potato, banana, corn, and cassava starches. Int. J. Biol. Macromol. 2019, 132, 32-42. [CrossRef]

32. Bertoft, E.; Blennow, A. Chapter 3-Structure of Potato Starch. In Advances in Potato Chemistry and Technology, 2nd ed.; Singh, J., Kaur, L., Eds.; Academic Press: Cambridge, MA, USA, 2016; pp. 57-73. [CrossRef]

33. Zhu, J.; Zhang, S.; Zhang, B.; Qiao, D.; Pu, H.; Liu, S.; Li, L. Structural features and thermal property of propionylated starches with different amylose/amylopectin ratio. Int. J. Biol. Macromol. 2017, 97, 123-130. [CrossRef]

34. Keeratiburana, T.; Hansen, A.R.; Soontaranon, S.; Blennow, A.; Tongta, S. Porous high amylose rice starch modified by amyloglucosidase and maltogenic $\alpha$-amylase. Carbohydr. Polym. 2020, 230, 115611. [CrossRef]

35. Singh, J.; Colussi, R.; McCarthy, O.J.; Kaur, L. Chapter 8-Potato Starch and Its Modification. In Advances in Potato Chemistry and Technology, 2nd ed.; Singh, J., Kaur, L., Eds.; Academic Press: Cambridge, MA, USA, 2016; pp. 195-247. [CrossRef]

36. Li, H.; Prakash, S.; Nicholson, T.M.; Fitzgerald, M.A.; Gilbert, R.G. The importance of amylose and amylopectin fine structure for textural properties of cooked rice grains. Food Chem. 2016, 196, 702-711. [CrossRef] [PubMed]

37. Palviainen, P.; Heinämäki, J.; Myllärinen, P.; Lahtinen, R.; Yliruusi, J.; Forssell, P. Corn Starches as Film Formers in Aqueous-Based Film Coating. Pharm. Dev. Technol. 2001, 6, 353-361. [CrossRef]

38. Shevkani, K.; Singh, N.; Bajaj, R.; Kaur, A. Wheat starch production, structure, functionality and applications-a review. Int. J. Food Sci. Technol. 2017, 52, 38-58. [CrossRef]

39. Semeijn, C.; Buwalda, P.L. Chapter 9-Potato Starch. In Woodhead Publishing Series in Food Science, Technology and Nutrition, 2nd ed.; Sjöö, M., Nilsson, L., Eds.; Woodhead Publishing: Cambridge, UK, 2018; pp. 353-372. [CrossRef]

40. Khan, B.; Bilal Khan Niazi, M.; Samin, G.; Jahan, Z. Thermoplastic Starch: A Possible Biodegradable Food Packaging Material-A Review. J. Food Process Eng. 2017, 40, e12447. [CrossRef] 
41. Gironès, J.; López, J.P.; Mutjé, P.; Carvalho, A.J.F.; Curvelo, A.A.S.; Vilaseca, F. Natural fiber-reinforced thermoplastic starch composites obtained by melt processing. Compos. Sci. Technol. 2012, 72, 858-863. [CrossRef]

42. Díaz-Galindo, E.P.; Nesic, A.; Cabrera-Barjas, G.; Mardones, C.; von Baer, D.; Bautista-Baños, S.; Dublan Garcia, O. PhysicalChemical Evaluation of Active Food Packaging Material Based on Thermoplastic Starch Loaded with Grape cane Extract. Molecules 2020, 25, 1306. [CrossRef]

43. Dorigato, A.; Perin, D.; Pegoretti, A. Effect of the Temperature and of the Drawing Conditions on the Fracture Behaviour of Thermoplastic Starch Films for Packaging Applications. J. Polym. Environ. 2020, 28, 3244-3255. [CrossRef]

44. Schmitt, H.; Guidez, A.; Prashantha, K.; Soulestin, J.; Lacrampe, M.F.; Krawczak, P. Studies on the effect of storage time and plasticizers on the structural variations in thermoplastic starch. Carbohydr. Polym. 2015, 115, 364-372. [CrossRef]

45. López, O.V.; Castillo, L.A.; García, M.A.; Villar, M.A.; Barbosa, S.E. Food packaging bags based on thermoplastic corn starch reinforced with talc nanoparticles. Food Hydrocoll. 2015, 43, 18-24. [CrossRef]

46. Jabeen, N.; Majid, I.; Nayik, G.A.; Yildiz, F. Bioplastics and food packaging: A review. Cogent Food Agric. $2015,1,1117749$. [CrossRef]

47. Sengupta, T.; Han, J.H. Chapter 4-Surface Chemistry of Food, Packaging, and Biopolymer Materials. In Innovations in Food Packaging, 2nd ed.; Han, J.H., Ed.; Academic Press: Cambridge, MA, USA, 2014; pp. 51-86. [CrossRef]

48. Gardner, K.H.; Blackwell, J. The structure of native cellulose. Biopolymers 1974, 13, 1975-2001. [CrossRef]

49. Trache, D.; Hussin, M.H.; Hui Chuin, C.T.; Sabar, S.; Fazita, M.R.N.; Taiwo, O.F.A.; Hassan, T.M.; Haafiz, M.K.M. Microcrystalline cellulose: Isolation, characterization and bio-composites application-A review. Int. J. Biol. Macromol. 2016, 93, 789-804. [CrossRef] [PubMed]

50. Trache, D.; Hussin, M.H.; Haafiz, M.K.M.; Thakur, V.K. Recent progress in cellulose nanocrystals: Sources and production. Nanoscale 2017, 9, 1763-1786. [CrossRef] [PubMed]

51. Mishra, S.; Kharkar, P.S.; Pethe, A.M. Biomass and waste materials as potential sources of nanocrystalline cellulose: Comparative review of preparation methods (2016-Till date). Carbohydr. Polym. 2019, 207, 418-427. [CrossRef] [PubMed]

52. Zhao, Y.; Moser, C.; Lindström, M.E.; Henriksson, G.; Li, J. Cellulose Nanofibers from Softwood, Hardwood, and Tunicate: Preparation-Structure-Film Performance Interrelation. ACS Appl. Mater. Interfaces 2017, 9, 13508-13519. [CrossRef]

53. Heinze, T.; El Seoud, O.A.; Koschella, A. Production and Characteristics of Cellulose from Different Sources. In Cellulose Derivatives, 1st ed.; Springer Series on Polymer and Composite Materials; Heinze, T., El Seoud, O.A., Koschella, A., Eds.; Springer: Cham, Switzerland, 2018; pp. 1-38. [CrossRef]

54. Zhang, B.; Azuma, J.; Uyama, H. Preparation and characterization of a transparent amorphous cellulose film. RSC Adv. 2015, 5, 2900-2907. [CrossRef]

55. Azeredo, H.M.C.; Barud, H.; Farinas, C.S.; Vasconcellos, V.M.; Claro, A.M. Bacterial Cellulose as a Raw Material for Food and Food Packaging Applications. Front. Sustain. Food Syst. 2019, 3. [CrossRef]

56. Azeredo, H.M.C.; Rosa, M.F.; Mattoso, L.H.C. Nanocellulose in bio-based food packaging applications. Ind. Crops Prod. 2017, 97, 664-671. [CrossRef]

57. Robertson, G.L. Food Packaging Principles and Practice, 3rd ed.; CRC Press: Boca Raton, FL, USA, 2012; 733p.

58. Wu, Y.; Li, Q.; Zhang, X.; Li, Y.; Li, B.; Liu, S. Cellulose-based peptidopolysaccharides as cationic antimicrobial package films. Int. J. Biol. Macromol. 2019, 128, 673-680. [CrossRef] [PubMed]

59. Da Silva Filipini, G.; Romani, V.P.; Guimarães Martins, V. Biodegradable and active-intelligent films based on methylcellulose and jambolão (Syzygium cumini) skins extract for food packaging. Food Hydrocoll. 2020, 109, 106139. [CrossRef]

60. López de Dicastillo, C.; Rodríguez, F.; Guarda, A.; Galotto, M.J. Antioxidant films based on cross-linked methyl cellulose and native Chilean berry for food packaging applications. Carbohydr. Polym. 2016, 136, 1052-1060. [CrossRef]

61. Yoo, S.; Krochta, J.M. Starch-methylcellulose-whey protein film properties. Int. J. Food Sci. Technol. 2012, 47, 255-261. [CrossRef]

62. Debeaufort, F. Lipid hydrophobicity and physical state effects on the properties of bilayer edible films. J. Membr. Sci. 2000, 180, 47-55. [CrossRef]

63. Heinze, T.; Pfeiffer, K. Studies on the synthesis and characterization of carboxymethylcellulose. Die Angew. Makromol. Chem. 1999, 266, 37-45. [CrossRef]

64. Roy, N.; Saha, N.; Kitano, T.; Saha, P. Biodegradation of PVP-CMC hydrogel film: A useful food packaging material. Carbohydr. Polym. 2012, 89, 346-353. [CrossRef]

65. Malhotra, B.; Keshwani, A.; Kharkwal, H. Natural polymer based cling films for food packaging. Int. J. Pharm. Pharm. Sci. 2015, 7, 10-18.

66. Rachtanapun, P.; Rattanapanone, N. Synthesis and characterization of carboxymethyl cellulose powder and films from Mimosa pigra. J. Appl. Polym. Sci. 2011, 122, 3218-3226. [CrossRef]

67. He, X.; Lu, W.; Sun, C.; Khalesi, H.; Mata, A.; Andaleeb, R.; Fang, Y. Cellulose and cellulose derivatives: Different colloidal states and food-related applications. Carbohydr. Polym. 2021, 255, 117334. [CrossRef] [PubMed]

68. Youssef, A.M.; El-Sayed, S.M. Bionanocomposites materials for food packaging applications: Concepts and future outlook. Carbohydr. Polym. 2018, 193, 19-27. [CrossRef] [PubMed]

69. Jolie, R.P.; Duvetter, T.; Van Loey, A.M.; Hendrickx, M.E. Pectin methylesterase and its proteinaceous inhibitor: A review. Carbohydr. Res. 2010, 345, 2583-2595. [CrossRef] [PubMed] 
70. Kumar, M.; Tomar, M.; Saurabh, V.; Mahajan, T.; Punia, S.; Contreras, M. del M.; Rudra, S.G.; Kaur, C.; Kennedy, J.F. Emerging trends in pectin extraction and its anti-microbial functionalization using natural bioactives for application in food packaging. Trends Food Sci. Technol. 2020, 105, 223-237. [CrossRef]

71. Espitia, P.; Avena-Bustillos, R.J.; Du, W.-X.; Teófilo, R.F.; Soares, N.F.F.; McHugh, T.H. Optimal antimicrobial formulation and physical-mechanical properties of edible films based on açaí and pectin for food preservation. Food Packag. Shelf Life 2014, 2, 38-49. [CrossRef]

72. Espitia, P.; Du, W.-X.; Avena-Bustillos, R. de J.; Soares, N. de F.F.; McHugh, T.H. Edible films from pectin: Physical-mechanical and antimicrobial properties-A review. Food Hydrocoll. 2014, 35, 287-296. [CrossRef]

73. Mishra, R.K.; Banthia, A.K.; Majeed, A.B.A. Pectin based formulations for biomedical applications: A review. Asian J. Pharm. Clin. Res. 2012, 5, 1-7.

74. Gómez, B.; Gullón, B.; Yáñez, R.; Schols, H.; Alonso, J.L. Prebiotic potential of pectins and pectic oligosaccharides derived from lemon peel wastes and sugar beet pulp: A comparative evaluation. J. Funct. Foods 2016, 20, 108-121. [CrossRef]

75. Ciriminna, R.; Fidalgo, A.; Delisi, R.; Ilharco, L.M.; Pagliaro, M. Pectin production and global market. Agro Food Ind. Hi Tech 2016, $27,17-20$.

76. Raei, M.; Shahidi, F.; Farhoodi, M.; Jafari, S.M.; Rafe, A. Application of whey protein-pectin nano-complex carriers for loading of lactoferrin. Int. J. Biol. Macromol. 2017, 105, 281-291. [CrossRef]

77. Sganzerla, W.G.; Rosa, G.B.; Ferreira, A.L.A.; Rosa, C.G.d.; Beling, P.C.; Xavier, L.O.; Hansen, C.M.; Ferrareze, J.P.; Nunes, M.R.; Barreto, P.L.M.; et al. Bioactive food packaging based on starch, citric pectin and functionalized with Acca sellowiana waste by-product: Characterization and application in the postharvest conservation of apple. Int. J. Biol. Macromol. 2020, 147, 295-303. [CrossRef]

78. Valdés, A.; Burgos, N.; Jiménez, A.; Garrigós, M. Natural Pectin Polysaccharides as Edible Coatings. Coatings 2015, 5, 865-886. [CrossRef]

79. Rodríguez-Núñez, J.R.; Madera-Santana, T.J.; Sánchez-Machado, D.I.; López-Cervantes, J.; Soto Valdez, H. Chitosan/Hydrophilic Plasticizer-Based Films: Preparation, Physicochemical and Antimicrobial Properties. J. Polym. Environ. 2014, 22, 41-51. [CrossRef]

80. Kaczmarek, M.B.; Struszczyk-Swita, K.; Li, X.; Szczęsna-Antczak, M.; Daroch, M. Enzymatic Modifications of Chitin, Chitosan, and Chitooligosaccharides. Front. Bioeng. Biotechnol. 2019, 7, 243. [CrossRef]

81. Younes, I.; Rinaudo, M. Chitin and Chitosan Preparation from Marine Sources. Structure, Properties and Applications. Mar. Drugs 2015, 13, 1133-1174. [CrossRef] [PubMed]

82. Bastiaens, L.; Soetemans, L.; D’Hondt, E.; Elst, K. Chapter 1 Sources of Chitin and Chitosan and their Isolation. In Chitin and Chitosan: Properties and Applications, 1st ed.; van den Broek, L.A.M., Boeriu, C.G., Eds.; John Wiley \& Sons Ltd: Hoboken, NJ, USA, 2019; pp. 1-34. [CrossRef]

83. Abdou, E.S.; Nagy, K.S.A.; Elsabee, M.Z. Extraction and characterization of chitin and chitosan from local sources. Bioresour. Technol. 2008, 99, 1359-1367. [CrossRef] [PubMed]

84. Kaya, M.; Cakmak, Y.S.; Baran, T.; Asan-Ozusaglam, M.; Mentes, A.; Tozak, K.O. New chitin, chitosan, and O-carboxymethyl chitosan sources from resting eggs of Daphnia longispina (Crustacea); with physicochemical characterization, and antimicrobial and antioxidant activities. Biotechnol. Bioprocess Eng. 2014, 19, 58-69. [CrossRef]

85. Majtán, J.; Bíliková, K.; Markovič, O.; Gróf, J.; Kogan, G.; Šimúth, J. Isolation and characterization of chitin from bumblebee (Bombus terrestris). Int. J. Biol. Macromol. 2007, 40, 237-241. [CrossRef]

86. Yen, M.-T.; Mau, J.-L. Physico-chemical characterization of fungal chitosan from shiitake stipes. LWT Food Sci. Technol. 2007, 40, 472-479. [CrossRef]

87. Rasul, R.M.; Muniandy, M.T.; Zakaria, Z.; Shah, K.; Chee, C.F.; Dabbagh, A.; Rahman, N.A.; Wong, T.W. A review on chitosan and its development as pulmonary particulate anti-infective and anti-cancer drug carriers. Carbohydr. Polym. 2020, 250, 116800. [CrossRef] [PubMed]

88. Yeul, V.S.; Rayalu, S.S. Unprecedented Chitin and Chitosan: A Chemical Overview. J. Polym. Environ. 2013, 21, 606-614. [CrossRef]

89. Elieh-Ali-Komi, D.; Hamblin, M.R. Chitin and Chitosan: Production and Application of Versatile Biomedical Nanomaterials. Int. J. Adv. Res. 2016, 4, 411-427.

90. Muxika, A.; Etxabide, A.; Uranga, J.; Guerrero, P.; de la Caba, K. Chitosan as a bioactive polymer: Processing, properties and applications. Int. J. Biol. Macromol. 2017, 105, 1358-1368. [CrossRef]

91. Jayakumar, R.; Nwe, N.; Tokura, S.; Tamura, H. Sulfated chitin and chitosan as novel biomaterials. Int. J. Biol. Macromol. 2007, 40, 175-181. [CrossRef]

92. Domján, A.; Bajdik, J.; Pintye-Hódi, K. Understanding of the Plasticizing Effects of Glycerol and PEG 400 on Chitosan Films Using Solid-State NMR Spectroscopy. Macromolecules 2009, 42, 4667-4673. [CrossRef]

93. Liu, H.; Adhikari, R.; Guo, Q.; Adhikari, B. Preparation and characterization of glycerol plasticized (high-amylose) starch-chitosan films. J. Food Eng. 2013, 116, 588-597. [CrossRef]

94. Bilbao-Sainz, C.; Chiou, B.-S.; Williams, T.; Wood, D.; Du, W.-X.; Sedej, I.; Ban, Z.; Rodov, V.; Poverenov, E.; Vinokur, Y.; et al. Vitamin D-fortified chitosan films from mushroom waste. Carbohydr. Polym. 2017, 167, 97-104. [CrossRef] [PubMed]

95. Kalaycıŏlu, Z.; Torlak, E.; Akın-Evingür, G.; Özen, İ.; Erim, F.B. Antimicrobial and physical properties of chitosan films incorporated with turmeric extract. Int. J. Biol. Macromol. 2017, 101, 882-888. [CrossRef] [PubMed] 
96. Lee, M.H.; Kim, S.Y.; Park, H.J. Effect of halloysite nanoclay on the physical, mechanical, and antioxidant properties of chitosan films incorporated with clove essential oil. Food Hydrocoll. 2018, 84, 58-67. [CrossRef]

97. Parreidt, T.S.; Müller, K.; Schmid, M. Alginate-Based Edible Films and Coatings for Food Packaging Applications. Foods 2018, 7, 170. [CrossRef]

98. Emmerichs, N.; Wingender, J.; Flemming, H.-C.; Mayer, C. Interaction between alginates and manganese cations: Identification of preferred cation binding sites. Int. J. Biol. Macromol. 2004, 34, 73-79. [CrossRef]

99. Evans, L.R.; Linker, A. Production and Characterization of the Slime Polysaccharide of Pseudomonas aeruginosa. J. Bacteriol. 1973, 116, 915-924. [CrossRef]

100. Hay, I.D.; Rehman, Z.U.; Moradali, M.F.; Wang, Y.; Rehm, B.H.A. Microbial alginate production, modification and its applications Microb. Biotechnol. 2013, 6, 637-650. [CrossRef]

101. Urtuvia, V.; Maturana, N.; Acevedo, F.; Peña, C.; Díaz-Barrera, A. Bacterial alginate production: An overview of its biosynthesis and potential industrial production. World J. Microbiol. Biotechnol. 2017, 33, 198. [CrossRef]

102. Flores, C.; Díaz-Barrera, A.; Martínez, F.; Galindo, E.; Peña, C. Role of oxygen in the polymerization and de-polymerization of alginate produced by Azotobacter vinelandii. J. Chem. Technol. Biotechnol. 2015, 90, 356-365. [CrossRef]

103. Hay, I.D.; Wang, Y.; Moradali, M.F.; Rehman, Z.U.; Rehm, B.H.A. Genetics and regulation of bacterial alginate production. Environ. Microbiol. 2014, 16, 2997-3011. [CrossRef] [PubMed]

104. Draget, K.I. Chapter 29 Alginates. In Handbook of Hydrocolloids, 2nd ed.; Phillips, G.O., Williams, P.A., Eds.; Woodhead Publishing Limited: Cambridge, UK, 2009; pp. 807-828.

105. Davidson, I.W.; Sutherland, I.W.; Lawson, C.J. Localization of O-Acetyl Groups of Bacterial Alginate. J. Gen. Microbiol. 1977, 98 , 603-606. [CrossRef]

106. Clementi, F. Alginate Production by Azotobacter Vinelandii. Crit. Rev. Biotechnol. 1997, 17, 327-361. [CrossRef] [PubMed]

107. Kimica Corporation. How to Use Alginates. Available online: https://kimica-algin.com/alginate/usage/ (accessed on 11 May 2020).

108. U.S. Food \& Drug Administration. Code for Federal Regulations Title 21 Part 184—Direct Food Substances Affirmed as Generally Recognized as Safe. Available online: https://www.accessdata.fda.gov/scripts/cdrh/cfdocs/cfcfr/CFRSearch.cfm?fr=184.1724 (accessed on 11 May 2020).

109. Younes, M.; Aggett, P.; Aguilar, F.; Crebelli, R.; Filipič, M.; Frutos, M.J.; Galtier, P.; Gott, D.; Gundert-Remy, U.; Kuhnle, G.G.; et al. Re-evaluation of alginic acid and its sodium, potassium, ammonium and calcium salts (E 400-E 404) as food additives. EFSA J. 2017, 15. [CrossRef]

110. Kim, Y.-J.; Yoon, K.-J.; Ko, S.-W. Preparation and properties of alginate superabsorbent filament fibers crosslinked with glutaraldehyde. J. Appl. Polym. Sci. 2000, 78, 1797-1804. [CrossRef]

111. Makaremi, M.; Yousefi, H.; Cavallaro, G.; Lazzara, G.; Goh, C.B.S.; Lee, S.M.; Solouk, A.; Pasbakhsh, P. Safely Dissolvable and Healable Active Packaging Films Based on Alginate and Pectin. Polymers 2019, 11, 1594. [CrossRef]

112. Cao, L.; Lu, W.; Mata, A.; Nishinari, K.; Fang, Y. Egg-box model-based gelation of alginate and pectin: A review. Carbohydr. Polym. 2020, 242, 116389. [CrossRef]

113. Chen, H.; Wang, J.; Cheng, Y.; Wang, C.; Liu, H.; Bian, H.; Pan, Y.; Sun, J.; Han, W. Application of Protein-Based Films and Coatings for Food Packaging: A Review. Polymers 2019, 11, 2039. [CrossRef]

114. Picchio, M.L.; Linck, Y.G.; Monti, G.A.; Gugliotta, L.M.; Minari, R.J.; Alvarez Igarzabal, C.I. Casein films crosslinked by tannic acid for food packaging applications. Food Hydrocoll. 2018, 84, 424-434. [CrossRef]

115. Bonnaillie, L.M.; Zhang, H.; Akkurt, S.; Yam, K.L.; Tomasula, P.M. Casein Films: The Effects of Formulation, Environmental Conditions and the Addition of Citric Pectin on the Structure and Mechanical Properties. Polymers 2014, 6, 2018-2036. [CrossRef]

116. Chiralt, A.; González-Martínez, C.; Vargas, M.; Atarés, L. 18 - Edible films and coatings from proteins. In Proteins in Food Processing, 2nd ed.; Yada, R.Y., Ed.; Woodhead Publishing: Cambridge, UK, 2018; pp. 477-500. [CrossRef]

117. Horne, D.S. Casein micelle structure: Models and muddles. Curr. Opin. Colloid Interface Sci. 2006, 11, 148-153. [CrossRef]

118. Sarode, A.R.; Sawale, P.D.; Khedkar, C.D.; Kalyankar, S.D.; Pawshe, R.D. Casein and Caseinate: Methods of Manufacture. In Encyclopedia of Food and Health, 1st ed.; Caballero, B., Finglas, P.M., Toldrá, F., Eds.; Academic Press: Cambridge, MA, USA, 2016; pp. 676-682. [CrossRef]

119. Lawrence, N.D.; Kentish, S.E.; O'Connor, A.J.; Barber, A.R.; Stevens, G.W. Microfiltration of skim milk using polymeric membranes for casein concentrate manufacture. Sep. Purif. Technol. 2008, 60, 237-244. [CrossRef]

120. Alekseev, G.V.; Khripov, A.A. Method of Rapid Remote Control of Casein Concentration in Dairy Products in Unopened Packages. J. Food Process Eng. 2015, 38, 11-18. [CrossRef]

121. Carr, A.; Golding, M. Functional Milk Proteins Production and Utilization: Casein-Based Ingredients. In Advanced Dairy Chemistry, 4th ed.; McSweeney, P., O’Mahony, J., Eds.; Springer: New York, NY, USA, 2016; Volume 1B, pp. 35-66. [CrossRef]

122. Chevalier, E.; Assezat, G.; Prochazka, F.; Oulahal, N. Development and characterization of a novel edible extruded sheet based on different casein sources and influence of the glycerol concentration. Food Hydrocoll. 2018, 75, 182-191. [CrossRef]

123. Xu, J.-L.; Gowen, A.A. Investigation of plasticizer aggregation problem in casein based biopolymer using chemical imaging. Talanta 2019, 193, 128-138. [CrossRef] [PubMed]

124. Farhan, A.; Hani, N.M. Characterization of edible packaging films based on semi-refined kappa-carrageenan plasticized with glycerol and sorbitol. Food Hydrocoll. 2017, 64, 48-58. [CrossRef] 
125. Ucpinar Durmaz, B.; Aytac, A. Poly (vinyl alcohol) and casein films: The effects of glycerol amount on the properties of films. Res. Eng. Struct. Mater. 2019, 5, 155-165. [CrossRef]

126. Cao, N.; Fu, Y.; He, J. Mechanical properties of gelatin films cross-linked, respectively, by ferulic acid and tannin acid. Food Hydrocoll. 2007, 21, 575-584. [CrossRef]

127. Lin, H.-C.; Wang, B.-J.; Weng, Y.-M. Development and characterization of sodium caseinate edible films cross-linked with genipin. LWT 2020, 118, 108813. [CrossRef]

128. Sabbah, M.; Giosafatto, C.V.L.; Esposito, M.; Di Pierro, P.; Mariniello, L.; Porta, R. Chapter 21-Transglutaminase Cross-Linked Edible Films and Coatings for Food Applications. In Enzymes in Food Biotechnology, 1st ed.; Kuddus, M., Ed.; Academic Press: Cambridge, MA, USA, 2019; pp. 369-388. [CrossRef]

129. Silvipriya, K.; Kumar, K.; Bhat, A.; Kumar, B.; John, A.; Lakshmanan, P. Collagen: Animal Sources and Biomedical Application. J. Appl. Pharm. Sci. 2015, 123-127. [CrossRef]

130. Bhagwat, P.K.; Dandge, P.B. Collagen and collagenolytic proteases: A review. Biocatal. Agric. Biotechnol. 2018, 15, 43-55. [CrossRef]

131. Song, E.; Yeon Kim, S.; Chun, T.; Byun, H.-J.; Lee, Y.M. Collagen scaffolds derived from a marine source and their biocompatibility. Biomaterials 2006, 27, 2951-2961. [CrossRef] [PubMed]

132. Li, P.; Wu, G. Roles of dietary glycine, proline, and hydroxyproline in collagen synthesis and animal growth. Amino Acids 2018, 50, 29-38. [CrossRef]

133. Goyal, D.; Goyal, A.; Brittberg, M. Consideration of religious sentiments while selecting a biological product for knee arthroscopy. Knee Surg. Sports Traumatol. Arthrosc. 2013, 21, 1577-1586. [CrossRef]

134. Avila Rodríguez, M.I.; Rodríguez Barroso, L.G.; Sánchez, M.L. Collagen: A review on its sources and potential cosmetic applications. J. Cosmet. Dermatol. 2018, 17, 20-26. [CrossRef]

135. Sebald, A. Collagen. 2019. Available online: https://maxfacts.uk/treatment/other/medication/miscellaneous/collagen (accessed on 25 February 2021).

136. Dong, C.; Lv, Y. Application of Collagen Scaffold in Tissue Engineering: Recent Advances and New Perspectives. Polymers 2016, 8, 42. [CrossRef]

137. Jiang, Y.; Lan, W.; Sameen, D.E.; Ahmed, S.; Qin, W.; Zhang, Q.; Chen, H.; Dai, J.; He, L.; Liu, Y. Preparation and characterization of grass carp collagen-chitosan-lemon essential oil composite films for application as food packaging. Int. J. Biol. Macromol. 2020, 160, 340-351. [CrossRef]

138. Kozlowska, J.; Sionkowska, A.; Skopinska-Wisniewska, J.; Piechowicz, K. Northern pike (Esox lucius) collagen: Extraction, characterization and potential application. Int. J. Biol. Macromol. 2015, 81, 220-227. [CrossRef]

139. Ramos, M.; Valdés, A.; Beltrán, A.; Garrigós, M. Gelatin-Based Films and Coatings for Food Packaging Applications. Coatings 2016, 6, 41. [CrossRef]

140. Holman, B.W.B.; Kerry, J.P.; Hopkins, D.L. Meat packaging solutions to current industry challenges: A review. Meat Sci. 2018, 144, 159-168. [CrossRef] [PubMed]

141. Etxabide, A.; Uranga, J.; Guerrero, P.; de la Caba, K. Development of active gelatin films by means of valorisation of food processing waste: A review. Food Hydrocoll. 2017, 68, 192-198. [CrossRef]

142. Kaewruang, P.; Benjakul, S.; Prodpran, T. Molecular and functional properties of gelatin from the skin of unicorn leatherjacket as affected by extracting temperatures. Food Chem. 2013, 138, 1431-1437. [CrossRef]

143. Mariod, A.A.; Fadol, H.A. Gelatin, source, extraction and industrial applications. Acta Sci. Pol. Technol. Aliment. 2013, 12, 135-147.

144. Mhd Sarbon, N.; Badii, F.; Howell, N.K. Preparation and characterisation of chicken skin gelatin as an alternative to mammalian gelatin. Food Hydrocoll. 2013, 30, 143-151. [CrossRef]

145. Gómez-Guillén, M.C.; Giménez, B.; López-Caballero, M.E.; Montero, M.P. Functional and bioactive properties of collagen and gelatin from alternative sources: A review. Food Hydrocoll. 2011, 25, 1813-1827. [CrossRef]

146. Karayannakidis, P.D.; Zotos, A. Fish Processing By-Products as a Potential Source of Gelatin: A Review. J. Aquat. Food Prod. Technol. 2016, 25, 65-92. [CrossRef]

147. Siburian, W.Z.; Rochima, E.; Andriani, Y.; Praseptiangga, D. Fish gelatin (definition, manufacture, analysis of quality characteristics, and application): A review. Int. J. Fish. Aquat. Stud. 2020, 8, 90-95.

148. Kariduraganavar, M.Y.; Kittur, A.A.; Kamble, R.R. Chapter 1-Polymer Synthesis and Processing. In Natural and Synthetic Biomedical Polymers, 1st ed.; Kumbar, S.G., Laurencin, C.T., Deng, M., Eds.; Elsevier: Amsterdam, The Netherlands, $2014 ;$ pp. 1-31. [CrossRef]

149. Lee, B.; Lum, N.; Seow, L.; Lim, P.; Tan, L. Synthesis and Characterization of Types A and B Gelatin Methacryloyl for Bioink Applications. Materials 2016, 9, 797. [CrossRef]

150. Aksun Tümerkan, E.T.; Cansu, Ü.; Boran, G.; Mac Regenstein, J.; Özoğul, F. Physiochemical and functional properties of gelatin obtained from tuna, frog and chicken skins. Food Chem. 2019, 287, 273-279. [CrossRef] [PubMed]

151. Chandra, M.V.; Shamasundar, B.A. Texture Profile Analysis and Functional Properties of Gelatin from the Skin of Three Species of Fresh Water Fish. Int. J. Food Prop. 2015, 18, 572-584. [CrossRef]

152. Lassoued, I.; Jridi, M.; Nasri, R.; Dammak, A.; Hajji, M.; Nasri, M.; Barkia, A. Characteristics and functional properties of gelatin from thornback ray skin obtained by pepsin-aided process in comparison with commercial halal bovine gelatin. Food Hydrocoll. 2014, 41, 309-318. [CrossRef] 
153. Hosseini, S.F.; Rezaei, M.; Zandi, M.; Ghavi, F.F. Preparation and functional properties of fish gelatin-chitosan blend edible films. Food Chem. 2013, 136, 1490-1495. [CrossRef] [PubMed]

154. Scopel, B.S.; Ribeiro, M.E.; Dettmer, A.; Baldasso, C. Cornstarch-Gelatin Films: Commercial Gelatin Versus Chromed Leather Waste Gelatin and Evaluation of Drying Conditions. J. Polym. Environ. 2018, 26, 1998-2006. [CrossRef]

155. Mellinas, C.; Valdés, A.; Ramos, M.; Burgos, N.; del Carmen Garrigós, M.; Jiménez, A. Active edible films: Current state and future trends. J. Appl. Polym. Sci 2016, 133. [CrossRef]

156. Ortiz-Zarama, M.A.; Jiménez-Aparicio, A.R.; Solorza-Feria, J. Obtainment and partial characterization of biodegradable gelatin films with tannic acid, bentonite and glycerol. J. Sci. Food Agric. 2016, 96, 3424-3431. [CrossRef]

157. Suderman, N.; Isa, M.I.N.; Sarbon, N.M. The effect of plasticizers on the functional properties of biodegradable gelatin-based film: A review. Food Biosci. 2018, 24, 111-119. [CrossRef]

158. Zhao, Y.; Li, Z.; Yang, W.; Xue, C.; Wang, Y.; Dong, J.; Xue, Y. Modification of Gelatine with Galla chinensis Extract, a Natural Crosslinker. Int. J. Food Prop. 2016, 19, 731-744. [CrossRef]

159. Alemán, A.; González, F.; Arancibia, M.Y.; López-Caballero, M.E.; Montero, P.; Gómez-Guillén, M.C. Comparative study between film and coating packaging based on shrimp concentrate obtained from marine industrial waste for fish sausage preservation. Food Control 2016, 70, 325-332. [CrossRef]

160. Benbettaïeb, N.; Chambin, O.; Karbowiak, T.; Debeaufort, F. Release behavior of quercetin from chitosan-fish gelatin edible films influenced by electron beam irradiation. Food Control 2016, 66, 315-319. [CrossRef]

161. Fakhouri, F.M.; Martelli, S.M.; Caon, T.; Velasco, J.I.; Mei, L.H.I. Edible films and coatings based on starch/gelatin: Film properties and effect of coatings on quality of refrigerated Red Crimson grapes. Postharvest Biol. Technol. 2015, 109, 57-64. [CrossRef]

162. Taylor, M.M.; Lee, J.; Bumanlag, L.P.; Latona, R.J.; Brown, E.M. Biopolymers produced from gelatin and whey protein concentrate using polyphenols. J. Am. Leather Chem. Assoc. 2014, 109, 82-88.

163. Paul, S.K. Edible Films and Coatings for Fruits and Vegetables. In Encyclopedia of Renewable and Sustainable Materials, 1st ed.; Choudhury, I.A., Hashmi, S., Eds.; Elsevier: Amsterdam, The Netherlands, 2020; Volume 5, pp. 363-376. [CrossRef]

164. Dehghani, S.; Hosseini, S.V.; Regenstein, J.M. Edible films and coatings in seafood preservation: A review. Food Chem. 2018, 240, 505-513. [CrossRef] [PubMed]

165. Kouhi, M.; Prabhakaran, M.P.; Ramakrishna, S. Edible polymers: An insight into its application in food, biomedicine and cosmetics. Trends Food Sci. Technol. 2020, 103, 248-263. [CrossRef]

166. Han, J.H. Chapter 9-Edible Films and Coatings: A Review. In Innovations in Food Packaging, 2nd ed.; Han, J.H., Ed.; Academic Press: Cambridge, MA, USA, 2014; pp. 213-255. [CrossRef]

167. Ciannamea, E.M.; Stefani, P.M.; Ruseckaite, R.A. Physical and mechanical properties of compression molded and solution casting soybean protein concentrate based films. Food Hydrocoll. 2014, 38, 193-204. [CrossRef]

168. Hammann, F.; Schmid, M. Determination and Quantification of Molecular Interactions in Protein Films: A Review. Materials 2014, 7, 7975-7996. [CrossRef]

169. Park, H.J.; Byun, Y.J.; Kim, Y.T.; Whiteside, W.S.; Bae, H.J. Chapter 10_Processes and Applications for Edible Coating and Film Materials from Agropolymers In Innovations in Food Packaging, 2nd ed.; Han, J.H., Ed.; Academic Press: Cambridge, MA, USA, 2014; pp. 257-275. [CrossRef]

170. Semenova, M.G.; Moiseenko, D.V.; Grigorovich, N.V.; Anokhina, M.S.; Antipova, A.S.; Belyakova, L.E.; Polikarpov, Y.N.; Tsapkina, E.N. Chapter 6-Protein-Polysaccharide Interactions and Digestion of the Complex Particles. In Food Structures, Digestion and Health, 1st ed.; Boland, M., Golding, M., Singh, H., Eds.; Academic Press: Cambridge, MA, USA, 2014; pp. 169-192. [CrossRef]

171. Ochoa-Yepes, O.; Di Giogio, L.; Goyanes, S.; Mauri, A.; Famá, L. Influence of process (extrusion/thermo-compression, casting) and lentil protein content on physicochemical properties of starch films. Carbohydr. Polym. 2019, 208, 221-231. [CrossRef] [PubMed]

172. Yan, Q.; Hou, H.; Guo, P.; Dong, H. Effects of extrusion and glycerol content on properties of oxidized and acetylated corn starch-based films. Carbohydr. Polym. 2012, 87, 707-712. [CrossRef]

173. Jiang, W.J.; Tsai, M.L.; Liu, T. Chitin nanofiber as a promising candidate for improved salty taste. LWT Food Sci. Technol. 2017, 75, 65-71. [CrossRef]

174. Guilbert, S.; Cuq, B.; Gontard, N. Recent innovations in edible and/or biodegradable packaging materials. Food Addit. Contam. 1997, 14, 741-751. [CrossRef] [PubMed]

175. Jiménez, A.; Fabra, M.J.; Talens, P.; Chiralt, A. Edible and Biodegradable Starch Films: A Review. Food Bioprocess Technol. 2012, 5 , 2058-2076. [CrossRef]

176. Umaraw, P.; Verma, A.K. Comprehensive review on application of edible film on meat and meat products: An eco-friendly approach. Crit. Rev. Food Sci. Nutr. 2017, 57, 1270-1279. [CrossRef] [PubMed]

177. Ju, J.; Xie, Y.; Guo, Y.; Cheng, Y.; Qian, H.; Yao, W. Application of edible coating with essential oil in food preservation. Crit. Rev. Food Sci. Nutr. 2019, 59, 2467-2480. [CrossRef]

178. Andrade, R.D.; Skurtys, O.; Osorio, F.A. Atomizing Spray Systems for Application of Edible Coatings. Compr. Rev. Food Sci. Food Saf. 2012, 11, 323-337. [CrossRef]

179. Anukiruthika, T.; Sethupathy, P.; Wilson, A.; Kashampur, K.; Moses, J.A.; Anandharamakrishnan, C. Multilayer packaging: Advances in preparation techniques and emerging food applications. Compr. Rev. Food Sci. Food Saf. 2020, 19, 1156-1186. [CrossRef] [PubMed] 
180. Jeya, J.J.; Chandrasekaran, M.; Venkatesan, S.P.; Sriram, V.; Britto Joseph, G.; Mageshwaran, G.; Durairaj, R.B. Scaling up difficulties and commercial aspects of edible films for food packaging: A review. Trends Food Sci. Technol. 2020, 100, $210-222$. [CrossRef]

181. Regubalan, B.; Pandit, P.; Maiti, S.; Nadathur, G.T.; Mallick, A. Potential bio-based edible films, foams, and hydrogels for food packaging. In Bio-Based Materials for Food Packaging, 1st ed.; Ahmed, S., Ed.; Springer: Singapore, 2018; pp. 105-123. [CrossRef]

182. Zhang, W.; Shu, C.; Chen, Q.; Cao, J.; Jiang, W. The multi-layer film system improved the release and retention properties of cinnamon essential oil and its application as coating in inhibition to penicillium expansion of apple fruit. Food Chem. 2019, 299, 125109. [CrossRef]

183. Arnon-Rips, H.; Poverenov, E. Improving food products' quality and storability by using Layer by Layer edible coatings. Trends Food Sci. Technol. 2018, 75, 81-92. [CrossRef]

184. Debeaufort, F.; Voilley, A. Effect of surfactants and drying rate on barrier properties of emulsified edible films. Int. J. Food Sci. Technol. 2007, 30, 183-190. [CrossRef]

185. Otoni, C.G.; Avena-Bustillos, R.J.; Azeredo, H.M.C.; Lorevice, M.V.; Moura, M.R.; Mattoso, L.H.C.; McHugh, T.H. Recent Advances on Edible Films Based on Fruits and Vegetables-A Review. Compr. Rev. Food Sci. Food Saf. 2017, 16, 1151-1169. [CrossRef]

186. Suhag, R.; Kumar, N.; Petkoska, A.T.; Upadhyay, A. Film formation and deposition methods of edible coating on food products: A review. Food Res. Int. 2020, 136, 109582. [CrossRef] [PubMed]

187. Aguirre-Joya, J.A.; De Leon-Zapata, M.A.; Alvarez-Perez, O.B.; Torres-León, C.; Nieto-Oropeza, D.E.; Ventura-Sobrevilla, J.M.; Aguilar, M.A.; Ruelas-Chacón, X.; Rojas, R.; Ramos-Aguiñaga, M.E.; et al. Chapter 1-Basic and Applied Concepts of Edible Packaging for Foods. In Handbook of Food Bioengineering, Food Packaging and Preservation, 1st ed.; Grumezescu, A.M., Holban, A.M., Eds.; Academic Press: Cambridge, MA, USA, 2018; Volume 9, pp. 1-61. [CrossRef]

188. Sharma, L.; Singh, C. Sesame protein based edible films: Development and characterization. Food Hydrocoll. 2016, 61, 139-147. [CrossRef]

189. De Moura, M.R.; Avena-Bustillos, R.J.; Mchugh, T.H.; Krochta, J.M.; Mattoso, L.H.C. Properties of Novel Hydroxypropyl Methylcellulose Films Containing Chitosan Nanoparticles. J. Food Sci. 2008, 73, 31-37. [CrossRef]

190. Chen, X.; Cui, F.; Zi, H.; Zhou, Y.; Liu, H.; Xiao, J. Development and characterization of a hydroxypropyl starch/zein bilayer edible film. Int. J. Biol. Macromol. 2019, 141, 1175-1182. [CrossRef] [PubMed]

191. Cao, L.; Liu, W.; Wang, L. Developing a green and edible film from Cassia gum: The effects of glycerol and sorbitol. J. Clean. Prod. 2018, 175, 276-282. [CrossRef]

192. Fishman, M.L.; Coffin, D.R.; Onwulata, C.I.; Konstance, R.P. Extrusion of pectin and glycerol with various combinations of orange albedo and starch. Carbohydr. Polym. 2004, 57, 401-413. [CrossRef]

193. Dangaran, K.; Tomasula, P.M.; Qi, P. Structure and Function of Protein-Based Edible Films and Coatings. In Edible Films and Coatings for Food Applications, 1st ed.; Huber, K., Embuscado, M., Eds.; Springer: New York, NY, USA, 2009; pp. 25-56. [CrossRef]

194. Cai, J.; Xiao, J.; Chen, X.; Liu, H. Essential oil loaded edible films prepared by continuous casting method: Effects of casting cycle and loading position on the release properties. Food Packag. Shelf Life 2020, 26, 100555. [CrossRef]

195. Dai, L.; Zhang, J.; Cheng, F. Effects of starches from different botanical sources and modification methods on physicochemical properties of starch-based edible films. Int. J. Biol. Macromol. 2019, 132, 897-905. [CrossRef]

196. Bagheri, F.; Radi, M.; Amiri, S. Drying conditions highly influence the characteristics of glycerol-plasticized alginate films. Food Hydrocoll. 2019, 90, 162-171. [CrossRef]

197. Fernández-Pan, I.; Ziani, K.; Pedroza-Islas, R.; Maté, J.I. Effect of drying conditions on the mechanical and barrier properties of films based on Chitosan. Dry. Technol. 2010, 28, 1350-1358. [CrossRef]

198. Chen, G.; Zhang, B.; Zhao, J.; Chen, H. Development and characterization of food packaging film fromcellulose sulfate. Food Hydrocoll. 2014, 35, 476-483. [CrossRef]

199. Liu, F.; Majeed, H.; Antoniou, J.; Li, Y.; Ma, Y.; Yokoyama, W.; Ma, J.; Zhong, F. Tailoring physical properties of transglutaminasemodified gelatin films by varying drying temperature. Food Hydrocoll. 2016, 58, 20-28. [CrossRef]

200. Hernandez-Izquierdo, V.M.; Reid, D.S.; McHugh, T.H.; De, J. Berrios, J.; Krochta, J.M. Thermal Transitions and Extrusion of Glycerol-Plasticized Whey Protein Mixtures. J. Food Sci. 2008, 73, E169-E175. [CrossRef] [PubMed]

201. Woggum, T.; Sirivongpaisal, P.; Wittaya, T. Properties and characteristics of dual-modified rice starch based biodegradable films. Int. J. Biol. Macromol. 2014, 67, 490-502. [CrossRef] [PubMed]

202. Skurtys, O.; Acevedo, C.; Pedreschi, F.; Enronoe, J.; Osorio, F.; Aguilera, J.M. Food Hydrocolloid Edible Films and Coatings; Nova Science Publishers Inc: New York, NY, USA, 2010; 66p.

203. Liu, L.; Kerry, J.F.; Kerry, J.P. Selection of optimum extrusion technology parameters in the manufacture of edible/ biodegradable packaging films derived from food-based polymers. J. Food Agric. Environ. 2005, 3, 51-58. [CrossRef]

204. Fitch-Vargas, P.R.; Aguilar-Palazuelos, E.; de Jesús Zazueta-Morales, J.; Vega-García, M.O.; Valdez-Morales, J.E.; Martínez-Bustos, F.; Jacobo-Valenzuela, N. Physicochemical and Microstructural Characterization of Corn Starch Edible Films Obtained by a Combination of Extrusion Technology and Casting Technique. J. Food Sci. 2016, 81, E2224-E2232. [CrossRef] [PubMed]

205. Zhang, S.; Gu, W.C.; Cheng, Z.Y.; Li, Y.; Gu, W.J. Development of edible packaging materials. Adv. Mater. Res. 2014, 904, 189-191. [CrossRef] 
206. Pelissari, F.M.; Yamashita, F.; Grossmann, M.V.E. Extrusion parameters related to starch/chitosan active films properties. Int. J. Food Sci. Technol. 2011, 46, 702-710. [CrossRef]

207. Kostic, M.M.; Reifschneider, L.G. Design of Extrusion Dies. In Encyclopedia of Chemical Processing, 1st ed.; Lee, S., Ed.; Taylor \& Francis Group: Abingdon-on-Thames, UK, 2006; pp. 633-649. [CrossRef]

208. Hernandez-Izquierdo, V.M.; Krochta, J.M. Thermoplastic processing of proteins for film formation-A review. J. Food Sci. 2008, 73, R30-R39. [CrossRef]

209. González-Seligra, P.; Guz, L.; Ochoa-Yepes, O.; Goyanes, S.; Famá, L. Influence of extrusion process conditions on starch film morphology. LWT 2017, 84, 520-528. [CrossRef]

210. Gilfillan, W.N.; Moghaddam, L.; Bartley, J.; Doherty, W.O.S. Thermal extrusion of starch film with alcohol. J. Food Eng. 2015, 170, 92-99. [CrossRef]

211. Calderón-Castro, A.; Vega-García, M.O.; de Jesús Zazueta-Morales, J.; Fitch-Vargas, P.R.; Carrillo-López, A.; Gutiérrez-Dorado, R.; Limón-Valenzuela, V.; Aguilar-Palazuelos, E. Effect of extrusion process on the functional properties of high amylose corn starch edible films and its application in mango (Mangifera indica L.) cv. Tommy Atkins. J. Food Sci. Technol. 2018, 55, 905-914. [CrossRef]

212. Fishman, M.L.; Coffin, D.R.; Konstance, R.P.; Onwulata, C.I. Extrusion of pectin/starch blends plasticized with glycerol. Carbohydr. Polym. 2000, 41, 317-325. [CrossRef]

213. Liu, L.; Kerry, J.F.; Kerry, J.P. Application and assessment of extruded edible casings manufactured from pectin and gelatin/sodium alginate blends for use with breakfast pork sausage. Meat Sci. 2007, 75, 196-202. [CrossRef]

214. Chevalier, E.; Chaabani, A.; Assezat, G.; Prochazka, F.; Oulahal, N. Casein/wax blend extrusion for production of edible films as carriers of potassium sorbate-A comparative study of waxes and potassium sorbate effect. Food Packag. Shelf Life 2018, 16, 41-50. [CrossRef]

215. Oechsle, A.M.; Häupler, M.; Weigel, F.; Gibis, M.; Kohlus, R.; Weiss, J. Modulation of extruded collagen films by the addition of co-gelling proteins. J. Food Eng. 2016, 171, 164-173. [CrossRef]

216. Belyamani, I.; Prochazka, F.; Assezat, G. Production and characterization of sodium caseinate edible films made by blown-film extrusion. J. Food Eng. 2014, 121, 39-47. [CrossRef]

217. Dang, K.M.; Yoksan, R. Development of thermoplastic starch blown film by incorporating plasticized chitosan. Carbohydr. Polym. 2015, 115, 575-581. [CrossRef]

218. Colak, B.Y.; Peynichou, P.; Galland, S.; Oulahal, N.; Assezat, G.; Prochazka, F.; Degraeve, P. Active biodegradable sodium caseinate films manufactured by blown-film extrusion: Effect of thermo-mechanical processing parameters and formulation on lysozyme stability. Ind. Crops Prod. 2015, 72, 142-151. [CrossRef]

219. Rodríguez-Castellanos, W.; Martínez-Bustos, F.; Rodrigue, D.; Trujillo-Barragán, M. Extrusion blow molding of a starch-gelatin polymer matrix reinforced with cellulose. Eur. Polym. J. 2015, 73, 335-343. [CrossRef]

220. Dierickx, L.; Saerens, L.; Almeida, A.; De Beer, T.; Remon, J.P.; Vervaet, C. Co-extrusion as manufacturing technique for fixed-dose combination mini-matrices. Eur. J. Pharm. Biopharm. 2012, 81, 683-689. [CrossRef] [PubMed]

221. Hilbig, J.; Hartlieb, K.; Herrmann, K.; Weiss, J.; Gibis, M. Influence of calcium on white efflorescence formation on dry fermented sausages with co-extruded alginate casings. Food Res. Int. 2020, 131, 109012. [CrossRef]

222. Harper, B.A.; Barbut, S.; Smith, A.; Marcone, M.F. Mechanical and Microstructural Properties of "Wet" Alginate and Composite Films Containing Various Carbohydrates. J. Food Sci. 2015, 80, E84-E92. [CrossRef] [PubMed]

223. Marcos, B.; Gou, P.; Arnau, J.; Guàrdia, M.D.; Comaposada, J. Co-extruded alginate as an alternative to collagen casings in the production of dry-fermented sausages: Impact of coating composition. Meat Sci. 2020, 169, 108184. [CrossRef]

224. Barbut, S.; Ioi, M.; Marcone, M. Co-extrusion of collagen casings. Effects of preparation, brining, and heating on strength, rheology and microstructure. Ital. J. Food Sci. 2020, 32, 91-106. [CrossRef]

225. Guerrero, P.; Stefani, P.M.; Ruseckaite, R.A.; De La Caba, K. Functional properties of films based on soy protein isolate and gelatin processed by compression molding. J. Food Eng. 2011, 105, 65-72. [CrossRef]

226. Tatara, R.A. 14 - Compression Molding. In Plastics Design Library, Applied Plastics Engineering Handbook, 2nd ed.; Kutz, M., Ed.; William Andrew Publishing: New York, NY, USA, 2017; pp. 291-320. [CrossRef]

227. Krishna, M.; Nindo, C.I.; Min, S.C. Development of fish gelatin edible films using extrusion and compression molding. J. Food Eng. 2012, 108, 337-344. [CrossRef]

228. Ceballos, R.L.; Ochoa-Yepes, O.; Goyanes, S.; Bernal, C.; Famá, L. Effect of yerba mate extract on the performance of starch films obtained by extrusion and compression molding as active and smart packaging. Carbohydr. Polym. 2020, 244, 116495. [CrossRef]

229. Uranga, J.; Etxabide, A.; Guerrero, P.; de la Caba, K. Development of active fish gelatin films with anthocyanins by compression molding. Food Hydrocoll. 2018, 84, 313-320. [CrossRef]

230. Ortega-Toro, R.; Jiménez, A.; Talens, P.; Chiralt, A. Properties of starch-hydroxypropyl methylcellulose based films obtained by compression molding. Carbohydr. Polym. 2014, 109, 155-165. [CrossRef] [PubMed]

231. Shen, C.; Wang, L.; Li, Q. Optimization of injection molding process parameters using combination of artificial neural network and genetic algorithm method. J. Mater. Process. Technol. 2007, 183, 412-418. [CrossRef]

232. Nussinovitch, A. CHAPTER 10-Biopolymer Films and Composite Coatings. In Modern Biopolymer Science, 1st ed.; Kasapis, S., Norton, I.T., Ubbink, J.B., Eds.; Academic Press: Cambridge, MA, USA, 2009; pp. 295-326. [CrossRef]

233. Perez, V.; Felix, M.; Romero, A.; Guerrero, A. Characterization of pea protein-based bioplastics processed by injection moulding. Food Bioprod. Process. 2016, 97, 100-108. [CrossRef] 
234. Yu, F.; Prashantha, K.; Soulestin, J.; Lacrampe, M.F.; Krawczak, P. Plasticized-starch/poly(ethylene oxide) blends prepared by extrusion. Carbohydr. Polym. 2013, 91, 253-261. [CrossRef] [PubMed]

235. Cho, S.W.; Gällstedt, M.; Johansson, E.; Hedenqvist, M.S. Injection-molded nanocomposites and materials based on wheat gluten. Int. J. Biol. Macromol. 2011, 48, 146-152. [CrossRef]

236. Raghav, P.K.; Agarwal, N.; Saini, M. Edible coating of fruits and vegetables: A review. Int. J. Sci. Res. Mod. Educ. 2016, 1, 188-204.

237. Pavlath, A.E.; Orts, W. Edible Films and Coatings: Why, What, and How? In Edible Films and Coatings for Food Applications, 1st ed.; Huber, K., Embuscado, M., Eds.; Springer: New York, NY, USA, 2009; pp. 1-23. [CrossRef]

238. Pelissari, F.M.; Ferreira, D.C.; Louzada, L.B.; Dos Santos, F.; Corrêa, A.C.; Moreira, F.K.V.; Mattoso, L.H. Chapter 10—Starch-Based Edible Films and Coatings: An Eco-friendly Alternative for Food Packaging. In Starches for Food Application, 1st ed.; Clerici, M.T.P.S., Schmiele, M., Eds.; Academic Press: Cambridge, MA, USA, 2018; pp. 359-420. [CrossRef]

239. Hassan, B.; Chatha, S.A.S.; Hussain, A.I.; Zia, K.M.; Akhtar, N. Recent advances on polysaccharides, lipids and protein based edible films and coatings: A review. Int. J. Biol. Macromol. 2018, 109, 1095-1107. [CrossRef] [PubMed]

240. Geschwindner, G.; Drouven, H. 18 - Manufacturing processes: Chocolate panning and inclusions. In Woodhead Publishing Series in Food Science, Technology and Nutrition, Science and Technology of Enrobed and Filled Chocolate, Confectionery and Bakery Products, 1st ed.; Talbot, G., Ed.; Woodhead Publishing: Cambridge, UK, 2009; pp. 397-413. [CrossRef]

241. Solís-Morales, D.; Sáenz-Hernández, C.M.; Ortega-Rivas, E. Attrition reduction and quality improvement of coated puffed wheat by fluidised bed technology. J. Food Eng. 2009, 93, 236-241. [CrossRef]

242. Wongphan, P.; Harnkarnsujarit, N. Characterization of starch, agar and maltodextrin blends for controlled dissolution of edible films. Int. J. Biol. Macromol. 2020, 156, 80-93. [CrossRef] [PubMed]

243. Guerreiro, A.C.; Gago, C.M.L.; Faleiro, M.L.; Miguel, M.G.C.; Antunes, M.D.C. The effect of edible coatings on the nutritional quality of 'Bravo de Esmolfe' fresh-cut apple through shelf-life. LWT Food Sci. Technol. 2017, 75, 210-219. [CrossRef]

244. Tavassoli-Kafrani, E.; Shekarchizadeh, H.; Masoudpour-Behabadi, M. Development of edible films and coatings from alginates and carrageenans. Carbohydr. Polym. 2016, 137, 360-374. [CrossRef] [PubMed]

245. Ribeiro, A.M.; Estevinho, B.N.; Rocha, F. Preparation and Incorporation of Functional Ingredients in Edible Films and Coatings. Food Bioprocess Technol. 2021, 14, 209-231. [CrossRef]

246. Atieno, L.; Owino, W.; Ateka, E.M.; Ambuko, J. Influence of Coating Application Methods on the Postharvest Quality of Cassava. Int. J. Food Sci. 2019, 2019, 2148914. [CrossRef] [PubMed]

247. Parreidt, T.S.; Schmid, M.; Müller, K. Effect of Dipping and Vacuum Impregnation Coating Techniques with Alginate Based Coating on Physical Quality Parameters of Cantaloupe Melon. J. Food Sci. 2018, 83, 929-936. [CrossRef] [PubMed]

248. Xiao, Z.; Luo, Y.; Luo, Y.; Wang, Q. Combined effects of sodium chlorite dip treatment and chitosan coatings on the quality of fresh-cut d'Anjou pears. Postharvest Biol. Technol. 2011, 62, 319-326. [CrossRef]

249. Hamzeh, A.; Rezaei, M. The Effects of Sodium Alginate on Quality of Rainbow Trout (Oncorhynchus mykiss) Fillets Stored at $4 \pm 2$ ${ }^{\circ}$ C. J. Aquat. Food Prod. Technol. 2012, 21, 14-21. [CrossRef]

250. Mastromatteo, M.; Mastromatteo, M.; Conte, A.; Del Nobile, M.A. Combined effect of active coating and MAP to prolong the shelf life of minimally processed kiwifruit (Actinidia deliciosa cv. Hayward). Food Res. Int. 2011, 44, 1224-1230. [CrossRef]

251. Hamzah, H.M.; Osman, A.; Tan, C.P.; Mohamad Ghazali, F. Carrageenan as an alternative coating for papaya (Carica papaya L. cv. Eksotika). Postharvest Biol. Technol. 2013, 75, 142-146. [CrossRef]

252. Kumar, N.; Neeraj. Polysaccharide-based component and their relevance in edible film/coating: A review. Nutr. Food Sci. 2019, 49, 793-823. [CrossRef]

253. Barringer, S.A.; Sumonsiri, N. Electrostatic Coating Technologies for Food Processing. Annu. Rev. Food Sci. Technol. 2015, 6, 157-169. [CrossRef]

254. Zhong, Y.; Zhuang, C.; Gu, W.; Zhao, Y. Effect of molecular weight on the properties of chitosan films prepared using electrostatic spraying technique. Carbohydr. Polym. 2019, 212, 197-205. [CrossRef]

255. Zhong, Y.; Cavender, G.; Zhao, Y. Investigation of different coating application methods on the performance of edible coatings on Mozzarella cheese. LWT Food Sci. Technol. 2014, 56, 1-8. [CrossRef]

256. Lara, G.; Yakoubi, S.; Villacorta, C.M.; Uemura, K.; Kobayashi, I.; Takahashi, C.; Nakajima, M.; Neves, M.A. Spray technology applications of xanthan gum-based edible coatings for fresh-cut lotus root (Nelumbo nucifera). Food Res. Int. 2020, 137, 109723. [CrossRef]

257. Peretto, G.; Du, W.X.; Avena-Bustillos, R.J.; Berrios, J.D.J.; Sambo, P.; McHugh, T.H. Electrostatic and Conventional Spraying of Alginate-Based Edible Coating with Natural Antimicrobials for Preserving Fresh Strawberry Quality. Food Bioprocess Technol. 2017, 10, 165-174. [CrossRef]

258. Zhuang, C.; Zhong, Y.; Zhao, Y. Effect of deacetylation degree on properties of Chitosan films using electrostatic spraying technique. Food Control 2019, 97, 25-31. [CrossRef]

259. Khanzadi, M.; Jafari, S.M.; Mirzaei, H.; Chegini, F.K.; Maghsoudlou, Y.; Dehnad, D. Physical and mechanical properties in biodegradable films of whey protein concentrate-pullulan by application of beeswax. Carbohydr. Polym. 2015, 118, 24-29. [CrossRef]

260. Ferreira Saraiva, L.E.; Naponucena, L.d.O.M.; de Silva Santos, V.; Silva, R.P.D.; de Souza, C.O.; Souza, I.E.G.L.; de Oliveira Mamede, M.E.; Druzian, J.I. Development and application of edible film of active potato starch to extend mini panettone shelf life. LWT Food Sci. Technol. 2016, 73, 311-319. [CrossRef] 
261. Da Rocha, M.; de Souza, M.M.; Prentice, C. Chapter 9-Biodegradable Films: An Alternative Food Packaging. In Handbook of Food Bioengineering, Food Packaging and Preservation, 1st ed.; Grumezescu, A.M., Holban, A.M., Eds.; Academic Press: Cambridge, MA, USA, 2018; Volume 9, pp. 307-342. [CrossRef]

262. Olivas, G.I.; Barbosa-Cánovas, G.V. Alginate-calcium films: Water vapor permeability and mechanical properties as affected by plasticizer and relative humidity. LWT Food Sci. Technol. 2008, 41, 359-366. [CrossRef]

263. Mikkonen, K.S.; Heikkinen, S.; Soovre, A.; Peura, M.; Serimaa, R.; Talja, R.A.; Helén, H.; Hyvönen, L.; Tenkanen, M. Films from oat spelt arabinoxylan plasticized with glycerol and sorbitol. J. Appl. Polym. Sci. 2009, 114, 457-466. [CrossRef]

264. Ansorena, M.R.; Pereda, M.; Marcovich, N.E. Edible films. In Polymers for Food Applications, 1st ed.; Gutiérrez, T., Ed.; Springer: Cham, Switzerland, 2018; pp. 5-24. [CrossRef]

265. Silva, M.A.; Bierhalz, A.C.K.; Kieckbusch, T.G. Alginate and pectin composite films crosslinked with Ca2+ ions: Effect of the plasticizer concentration. Carbohydr. Polym. 2009, 77, 736-742. [CrossRef]

266. Tillet, G.; Boutevin, B.; Ameduri, B. Chemical reactions of polymer crosslinking and post-crosslinking at room and medium temperature. Prog. Polym. Sci. 2011. [CrossRef]

267. Azeredo, H.M.C.; Waldron, K.W. Crosslinking in polysaccharide and protein films and coatings for food contact-A review. Trends Food Sci. Technol. 2016, 52, 109-122. [CrossRef]

268. Dole, P.; Joly, C.; Espuche, E.; Alric, I.; Gontard, N. Gas transport properties of starch based films. Carbohydr. Polym. 2004, 58, 335-343. [CrossRef]

269. Versino, F.; Lopez, O.V.; Garcia, M.A.; Zaritzky, N.E. Starch-based films and food coatings: An overview. Starch 2016, 68, 1026-1037. [CrossRef]

270. Prakash Maran, J.; Sivakumar, V.; Thirugnanasambandham, K.; Kandasamy, S. Modeling and analysis of film composition on mechanical properties of maize starch based edible films. Int. J. Biol. Macromol. 2013, 62, 565-573. [CrossRef] [PubMed]

271. Flores, S.; Famá, L.; Rojas, A.M.; Goyanes, S.; Gerschenson, L. Physical properties of tapioca-starch edible films: Influence of filmmaking and potassium sorbate. Food Res. Int. 2007, 40, 257-265. [CrossRef]

272. García, N.L.; Ribba, L.; Dufresne, A.; Aranguren, M.; Goyanes, S. Effect of glycerol on the morphology of nanocomposites made from thermoplastic starch and starch nanocrystals. Carbohydr. Polym. 2011, 84, 203-210. [CrossRef]

273. Avila-De La Rosa, G.; Carrillo-Navas, H.; Echeverría, J.C.; Bello-Pérez, L.A.; Vernon-Carter, E.J.; Alvarez-Ramirez, J. Mechanisms of elastic turbulence in gelatinized starch dispersions. Chaos Solitons Fractals 2015, 77, 29-38. [CrossRef]

274. Carrillo-Navas, H.; Avila-De La Rosa, G.; Gómez-Luría, D.; Meraz, M.; Alvarez-Ramirez, J.; Vernon-Carter, E.J. Impact of ghosts on the viscoelastic response of gelatinized corn starch dispersions subjected to small strain deformations. Carbohydr. Polym. 2014, 110, 156-162. [CrossRef] [PubMed]

275. Xu, J.; Xia, R.; Zheng, L.; Yuan, T.; Sun, R. Plasticized hemicelluloses/chitosan-based edible films reinforced by cellulose nanofiber with enhanced mechanical properties. Carbohydr. Polym. 2019, 224, 115164. [CrossRef] [PubMed]

276. Lumdubwong, N. Applications of Starch-Based Films in Food Packaging. In Reference Module in Food Science; Elsevier: Amsterdam, The Netherlands, 2019. [CrossRef]

277. Olsson, E.; Hedenqvist, M.S.; Johansson, C.; Järnström, L. Influence of citric acid and curing on moisture sorption, diffusion and permeability of starch films. Carbohydr. Polym. 2013, 94, 765-772. [CrossRef] [PubMed]

278. Olsson, E.; Menzel, C.; Johansson, C.; Andersson, R.; Koch, K.; Järnström, L. The effect of pH on hydrolysis, cross-linking and barrier properties of starch barriers containing citric acid. Carbohydr. Polym. 2013, 98, 1505-1513. [CrossRef] [PubMed]

279. Menzel, C. Improvement of starch films for food packaging through a three-principle approach: Antioxidants, cross-linking and reinforcement. Carbohydr. Polym. 2020, 250, 116828. [CrossRef]

280. Nawab, A.; Alam, F.; Haq, M.A.; Lutfi, Z.; Hasnain, A. Effect of mango kernel starch coatings on the shelf life of almond (Prunus dulcis) kernels. J. Food Process. Preserv. 2018, 42, e13449. [CrossRef]

281. Mehyar, G.F.; Han, J.H. Physical and Mechanical Properties of High-amylose Rice and Pea Starch Films as Affected by Relative Humidity and Plasticizer. J. Food Sci. 2006, 69, E449-E454. [CrossRef]

282. Chiumarelli, M.; Pereira, L.M.; Ferrari, C.C.; Sarantópoulos, C.I.G.L.; Hubinger, M.D. Cassava Starch Coating and Citric Acid to Preserve Quality Parameters of Fresh-Cut “Tommy Atkins” Mango. J. Food Sci. 2010, 75, E297-E304. [CrossRef] [PubMed]

283. Medronho, B.; Lindman, B. Brief overview on cellulose dissolution/regeneration interactions and mechanisms. Adv. Colloid Interface Sci. 2015, 222, 502-508. [CrossRef] [PubMed]

284. Medronho, B.; Lindman, B. Competing forces during cellulose dissolution: From solvents to mechanisms. Curr. Opin. Colloid Interface Sci. 2014, 19, 32-40. [CrossRef]

285. Wang, S.; Lu, A.; Zhang, L. Recent advances in regenerated cellulose materials. Prog. Polym. Sci. 2016, 53, 169-206. [CrossRef]

286. Cruz-Romero, M.C.; Cruz-Romero, M.; Kerry, J.P.; Kerry, J. Crop-based biodegradable packaging and its environmental implications. Nutr. Nat. Resour. 2008, 3, 1-25. [CrossRef]

287. Lindman, B.; Karlström, G.; Stigsson, L. On the mechanism of dissolution of cellulose. J. Mol. Liq. 2010, 156, 76-81. [CrossRef]

288. Medronho, B.; Romano, A.; Miguel, M.G.; Stigsson, L.; Lindman, B. Rationalizing cellulose (in)solubility: Reviewing basic physicochemical aspects and role of hydrophobic interactions. Cellulose 2012, 19, 581-587. [CrossRef]

289. Abe, M.; Fukaya, Y.; Ohno, H. Fast and facile dissolution of cellulose with tetrabutylphosphonium hydroxide containing $40 \mathrm{wt} \%$ water. Chem. Commun. 2012, 48, 1808-1810. [CrossRef] 
290. El Seoud, O.A.; Heinze, T. Organic esters of cellulose: New perspectives for old polymers. Adv. Polym. Sci. 2005, 186, 103-149. [CrossRef]

291. Egal, M.; Budtova, T.; Navard, P. Structure of aqueous solutions of microcrystalline cellulose/sodium hydroxide below $0{ }^{\circ} \mathrm{C}$ and the limit of cellulose dissolution. Biomacromolecules 2007, 8, 2282-2287. [CrossRef]

292. Lue, A.; Zhang, L. Advances in aqueous cellulose solvents. In Cellulose Solvents: For Analysis, Shaping and Chemical Modification, 1st ed.; Liebert, T., Heinze, T., Edgar, K.J., Eds.; American Chemical Society: Washington, DC, USA, 2010; Volume 1033, pp. 67-89. [CrossRef]

293. Heinze, T.; Köhler, S. Dimethyl sulfoxide and ammonium fluorides-novel cellulose solvents. In Cellulose Solvents: For Analysis, Shaping and Chemical Modification, 1st ed.; Liebert, T., Heinze, T., Edgar, K.J., Eds.; American Chemical Society: Washington, DC, USA, 2010; Volume 1033, pp. 103-118. [CrossRef]

294. Yang, Y.J.; Shin, J.M.; Kang, T.H.; Kimura, S.; Wada, M.; Kim, U.J. Cellulose dissolution in aqueous lithium bromide solutions. Cellulose 2014, 21, 1175-1181. [CrossRef]

295. Ferreira, A.; Alves, V.; Coelhoso, I. Polysaccharide-Based Membranes in Food Packaging Applications. Membranes 2016, 6, 22. [CrossRef] [PubMed]

296. Zhang, L.; Mao, Y.; Zhou, J.; Cai, J. Effects of Coagulation Conditions on the Properties of Regenerated Cellulose Films Prepared in $\mathrm{NaOH} /$ Urea Aqueous Solution. Ind. Eng. Chem. Res. 2005, 44, 522-529. [CrossRef]

297. Geng, H.; Yuan, Z.; Fan, Q.; Dai, X.; Zhao, Y.; Wang, Z.; Qin, M. Characterisation of cellulose films regenerated from acetone/water coagulants. Carbohydr. Polym. 2014, 102, 438-444. [CrossRef]

298. Qi, H.; Chang, C.; Zhang, L. Properties and applications of biodegradable transparent and photoluminescent cellulose films prepared via a green process. Green Chem. 2009, 11, 177-184. [CrossRef]

299. Bedane, A.H.; Eić, M.; Farmahini-Farahani, M.; Xiao, H. Water vapor transport properties of regenerated cellulose and nanofibrillated cellulose films. J. Membr. Sci. 2015, 493, 46-57. [CrossRef]

300. Dhall, R.K. Advances in Edible Coatings for Fresh Fruits and Vegetables: A Review. Crit. Rev. Food Sci. Nutr. 2013, 53, 435-450. [CrossRef] [PubMed]

301. Benito-González, I.; Jaén-Cano, C.M.; López-Rubio, A.; Martínez-Abad, A.; Martínez-Sanz, M. Valorisation of vine shoots for the development of cellulose-based biocomposite films with improved performance and bioactivity. Int. J. Biol. Macromol. 2020, 165, 1540-1551. [CrossRef]

302. Kwak, H.; Shin, S.; Kim, J.; Kim, J.; Lee, D.; Lee, H.; Lee, E.J.; Hyun, J. Protective coating of strawberries with cellulose nanofibers. Carbohydr. Polym. 2021, 258, 117688. [CrossRef]

303. Oun, A.A.; Rhim, J.W. Isolation of cellulose nanocrystals from grain straws and their use for the preparation of carboxymethyl cellulose-based nanocomposite films. Carbohydr. Polym. 2016, 150, 187-200. [CrossRef] [PubMed]

304. Li, H.; Shi, H.; He, Y.; Fei, X.; Peng, L. Preparation and characterization of carboxymethyl cellulose-based composite films reinforced by cellulose nanocrystals derived from pea hull waste for food packaging applications. Int. J. Biol. Macromol. 2020, 164, 4104-4112. [CrossRef] [PubMed]

305. Singh, P.; Magalhães, S.; Alves, L.; Antunes, F.; Miguel, M.; Lindman, B.; Medronho, B. Cellulose-based edible films for probiotic entrapment. Food Hydrocoll. 2019, 88, 68-74. [CrossRef]

306. Osorio, F.A.; Molina, P.; Matiacevich, S.; Enrione, J.; Skurtys, O. Characteristics of hydroxy propyl methyl cellulose (HPMC) based edible film developed for blueberry coatings. Procedia Food Sci. 2011, 1, 287-293. [CrossRef]

307. Azeredo, H.M.C.; Mattoso, L.H.C.; Avena-Bustillos, R.J.; Filho, G.C.; Munford, M.L.; Wood, D.; McHugh, T.H. Nanocellulose reinforced chitosan composite films as affected by nanofiller loading and plasticizer content. J. Food Sci. 2010, 75, N1-N7. [CrossRef] [PubMed]

308. Savadekar, N.R.; Karande, V.S.; Vigneshwaran, N.; Bharimalla, A.K.; Mhaske, S.T. Preparation of nano cellulose fibers and its application in kappa-carrageenan based film. Int. J. Biol. Macromol. 2012, 51, 1008-1013. [CrossRef] [PubMed]

309. Benito-González, I.; López-Rubio, A.; Martínez-Sanz, M. High-performance starch biocomposites with celullose from waste biomass: Film properties and retrogradation behaviour. Carbohydr. Polym. 2019, 216, 180-188. [CrossRef] [PubMed]

310. Lin, Z.; Xia, Y.; Yang, G.; Chen, J.; Ji, D. Improved film formability of oxidized starch-based blends through controlled modification with cellulose nanocrystals. Ind. Crops Prod. 2019, 140, 111665. [CrossRef]

311. Almasi, H.; Ghanbarzadeh, B.; Entezami, A.A. Physicochemical properties of starch-CMC-nanoclay biodegradable films. Int. J. Biol. Macromol. 2010, 46, 1-5. [CrossRef] [PubMed]

312. Tongdeesoontorn, W.; Mauer, L.J.; Wongruong, S.; Sriburi, P.; Rachtanapun, P. Effect of carboxymethyl cellulose concentration on physical properties of biodegradable cassava starch-based films. Chem. Cent. J. 2011, 5, 6. [CrossRef]

313. Azeredo, H.M.C.; Mattoso, L.H.C.; Wood, D.; Williams, T.G.; Avena-Bustillos, R.J.; McHugh, T.H. Nanocomposite edible films from mango puree reinforced with cellulose nanofibers. J. Food Sci. 2009, 74, N31-N35. [CrossRef]

314. Andrade-Pizarro, R.D.; Skurtys, O.; Osorio-Lira, F. Effect of cellulose nanofibers concentration on mechanical, optical, and barrier properties of gelatin-based edible films. DYNA 2015, 82, 219-226. [CrossRef]

315. Azeredo, H.M.C.; Miranda, K.W.E.; Ribeiro, H.L.; Rosa, M.F.; Nascimento, D.M. Nanoreinforced alginate-acerola puree coatings on acerola fruits. J. Food Eng. 2012, 113, 505-510. [CrossRef]

316. Wu, T.; Farnood, R.; O'Kelly, K.; Chen, B. Mechanical behavior of transparent nanofibrillar cellulose-chitosan nanocomposite films in dry and wet conditions. J. Mech. Behav. Biomed. Mater. 2014, 32, 279-286. [CrossRef] 
317. Gutierrez-Pacheco, M.M.; Ortega-Ramirez, L.A.; Cruz-Valenzuela, M.R.; Silva-Espinoza, B.A.; Gonzalez-Aguilar, G.A.; AyalaZavala, J.F. Chapter 50-Combinational Approaches for Antimicrobial Packaging: Pectin and Cinnamon Leaf Oil. In Antimicrobial Food Packaging, 1st ed.; Barros-Velázquez, J., Ed.; Academic Press: Cambridge, MA, USA, 2016; pp. 609-617. [CrossRef]

318. Coenen, G.J.; Bakx, E.J.; Verhoef, R.P.; Schols, H.A.; Voragen, A.G.J. Identification of the connecting linkage between homo- or xylogalacturonan and rhamnogalacturonan type I. Carbohydr. Polym. 2007, 70, 224-235. [CrossRef]

319. Eça, K.S.; Machado, M.T.C.; Hubinger, M.D.; Menegalli, F.C. Development of Active Films From Pectin and Fruit Extracts: Light Protection, Antioxidant Capacity, and Compounds Stability. J. Food Sci. 2015, 80, C2389-C2396. [CrossRef]

320. Munarin, F.; Tanzi, M.C.; Petrini, P. Advances in biomedical applications of pectin gels. Int. J. Biol. Macromol. 2012, 51, 681-689. [CrossRef] [PubMed]

321. Fraeye, I.; Duvetter, T.; Doungla, E.; Van Loey, A.; Hendrickx, M. Fine-tuning the properties of pectin-calcium gels by control of pectin fine structure, gel composition and environmental conditions. Trends Food Sci. Technol. 2010, 21, 219-228. [CrossRef]

322. Videcoq, P.; Garnier, C.; Robert, P.; Bonnin, E. Influence of calcium on pectin methylesterase behaviour in the presence of medium methylated pectins. Carbohydr. Polym. 2011, 86, 1657-1664. [CrossRef]

323. Thibault, J.-F.; Ralet, M.-C. Physico-Chemical Properties of Pectins in the Cell Walls and After Extraction. In Advances in Pectin and Pectinase Research, 1st ed.; Springer: Dordrecht, The Netherlands, 2003; pp. 91-105. [CrossRef]

324. Kuuva, T.; Lantto, R.; Reinikainen, T.; Buchert, J.; Autio, K. Rheological properties of laccase-induced sugar beet pectin gels. Food Hydrocoll. 2003, 17, 679-684. [CrossRef]

325. Galus, S.; Turska, A.; Lenart, A. Sorption and Wetting Properties of Pectin Edible Films. Czech J. Food Sci. 2012, 30, 446-455. [CrossRef]

326. Giancone, T.; Torrieri, E.; Pierro, P. Di, Cavella, S.; Giosafatto, C.V.L.; Masi, P. Effect of Surface Density on the Engineering Properties of High Methoxyl Pectin-Based Edible Films. Food Bioprocess Technol. 2011, 4, 1228-1236. [CrossRef]

327. Sucheta; Chaturvedi, K.; Sharma, N.; Yadav, S.K. Composite edible coatings from commercial pectin, corn flour and beetroot powder minimize post-harvest decay, reduces ripening and improves sensory liking of tomatoes. Int. J. Biol. Macromol. 2019, 133, 284-293. [CrossRef]

328. Darni, Y.; Utami, H.; Septiana, R.; Fitriana, R.A. Comparative studies of the edible film based on low pectin methoxyl with glycerol and sorbitol plasticizers. J. Bahan Alam Terbarukan 2017, 6, 158-167. [CrossRef]

329. Oms-Oliu, G.; Soliva-Fortuny, R.; Martín-Belloso, O. Edible coatings with antibrowning agents to maintain sensory quality and antioxidant properties of fresh-cut pears. Postharvest Biol. Technol. 2008, 50, 87-94. [CrossRef]

330. Ferrari, C.C.; Sarantópoulos, C.I.G.L.; Carmello-Guerreiro, S.M.; Hubinger, M.D. Effect of Osmotic Dehydration and Pectin Edible Coatings on Quality and Shelf Life of Fresh-Cut Melon. Food Bioprocess Technol. 2013, 6, 80-91. [CrossRef]

331. Moalemyan, M.; Ramaswamy, H.S.; Maftoonazad, N. Pectin-based edible coating for shelf-life extension of ataulfo mango. J. Food Process Eng. 2012, 35, 572-600. [CrossRef]

332. Sathivel, S.; Liu, Q.; Huang, J.; Prinyawiwatkul, W. The influence of chitosan glazing on the quality of skinless pink salmon (Oncorhynchus gorbuscha) fillets during frozen storage. J. Food Eng. 2007, 83, 366-373. [CrossRef]

333. Nguyen, T.T.; Thi Dao, U.T.; Thi Bui, Q.P.; Bach, G.L.; Ha Thuc, C.N.; Ha Thuc, H. Enhanced antimicrobial activities and physiochemical properties of edible film based on chitosan incorporated with Sonneratia caseolaris (L.) Engl. leaf extract. Prog. Org. Coat. 2020, 140, 105487. [CrossRef]

334. Kaur, S.; Dhillon, G.S. The versatile biopolymer chitosan: Potential sources, evaluation of extraction methods and applications. Crit. Rev. Microbiol. 2014, 40, 155-175. [CrossRef] [PubMed]

335. Leceta, I.; Guerrero, P.; De La Caba, K. Functional properties of chitosan-based films. Carbohydr. Polym. 2013, 93, 339-346. [CrossRef] [PubMed]

336. Hwang, K.T.; Kim, J.T.; Jung, S.T.; Cho, G.S.; Park, H.J. Properties of chitosan-based biopolymer films with various degrees of deacetylation and molecular weights. J. Appl. Polym. Sci. 2003, 89, 3476-3484. [CrossRef]

337. Fernandez-Saiz, P.; Lagaron, J.M.; Ocio, M.J. Optimization of the biocide properties of chitosan for its application in the design of active films of interest in the food area. Food Hydrocoll. 2009, 23, 913-921. [CrossRef]

338. Gao, H.X.; He, Z.; Sun, Q.; He, Q.; Zeng, W.C. A functional polysaccharide film forming by pectin, chitosan, and tea polyphenols. Carbohydr. Polym. 2019, 215, 1-7. [CrossRef]

339. Cerqueira, M.A.; Souza, B.W.S.; Teixeira, J.A.; Vicente, A.A. Effects of Interactions between the Constituents of Chitosan-Edible Films on Their Physical Properties. Food Bioprocess Technol. 2012, 5, 3181-3192. [CrossRef]

340. Elsabee, M.Z.; Abdou, E.S. Chitosan based edible films and coatings: A review. Mater. Sci. Eng. C 2013, 33, 1819-1841. [CrossRef]

341. Nayik, G.A.; Majid, I.; Kumar, V. Characterization of Indian Honeys View project Sprouted onion View project Developments in Edible films and Coatings for the extension of Shelf Life of Fresh Fruits. Am. J. Nutr. Food Sci. 2015, 2, 16-20. [CrossRef]

342. Duran, A.; Kahve, H.I. The use of chitosan as a coating material. Acad. J. Sci. 2016, 05, 167-172.

343. Van den Broek, L.A.M.; Knoop, R.J.I.; Kappen, F.H.J.; Boeriu, C.G. Chitosan films and blends for packaging material. Carbohydr. Polym. 2015, 116, 237-242. [CrossRef] [PubMed]

344. Pavinatto, A.; de Almeida Mattos, A.V.; Malpass, A.C.G.; Okura, M.H.; Balogh, D.T.; Sanfelice, R.C. Coating with chitosan-based edible films for mechanical/biological protection of strawberries. Int. J. Biol. Macromol. 2020, 151, 1004-1011. [CrossRef]

345. Mohan, C.O.; Ravishankar, C.N.; Lalitha, K.V.; Srinivasa Gopal, T.K. Effect of chitosan edible coating on the quality of double filleted Indian oil sardine (Sardinella longiceps) during chilled storage. Food Hydrocoll. 2012, 26, 167-174. [CrossRef] 
346. Duan, J.; Park, S.I.; Daeschel, M.A.; Zhao, Y. Antimicrobial chitosan-lysozyme (CL) films and coatings for enhancing microbial safety of mozzarella cheese. J. Food Sci. 2007, 72, M355-M362. [CrossRef]

347. Günlü, A.; Sipahioğlu, S.; Alpas, H. The effect of chitosan-based edible film and high hydrostatic pressure process on the microbiological and chemical quality of rainbow trout (Oncorhynchus mykiss Walbaum) fillets during cold storage $\left(4 \pm 1^{\circ} \mathrm{C}\right)$. High Press. Res. 2014, 34, 110-121. [CrossRef]

348. Günlü, A.; Koyun, E. Effects of Vacuum Packaging and Wrapping with Chitosan-Based Edible Film on the Extension of the Shelf Life of Sea Bass (Dicentrarchus labrax) Fillets in Cold Storage $\left(4^{\circ} \mathrm{C}\right)$. Food Bioprocess Technol. 2013, 6, 1713-1719. [CrossRef]

349. Vu, C.H.T.; Won, K. Novel water-resistant UV-activated oxygen indicator for intelligent food packaging. Food Chem. 2013, 140, 52-56. [CrossRef]

350. Priyadarshi, R.; Kim, H.J.; Rhim, J.W. Effect of sulfur nanoparticles on properties of alginate-based films for active food packaging applications. Food Hydrocoll. 2021, 110, 106155. [CrossRef]

351. Draget, K.I.; Taylor, C. Chemical, physical and biological properties of alginates and their biomedical implications. Food Hydrocoll. 2011, 25, 251-256. [CrossRef]

352. Blanco-Pascual, N.; Montero, M.P.; Gómez-Guillén, M.C. Antioxidant film development from unrefined extracts of brown seaweeds Laminaria digitata and Ascophyllum nodosum. Food Hydrocoll. 2014, 37, 100-110. [CrossRef]

353. Xu, L.; Zhang, B.; Qin, Y.; Li, F.; Yang, S.; Lu, P.; Wang, L.; Fan, J. Preparation and characterization of antifungal coating films composed of sodium alginate and cyclolipopeptides produced by Bacillus subtilis. Int. J. Biol. Macromol. 2020, 143, 602-609. [CrossRef] [PubMed]

354. Costa, M.J.; Marques, A.M.; Pastrana, L.M.; Teixeira, J.A.; Sillankorva, S.M.; Cerqueira, M.A. Physicochemical properties of alginate-based films: Effect of ionic crosslinking and mannuronic and guluronic acid ratio. Food Hydrocoll. 2018, 81, 442-448. [CrossRef]

355. Singh, P.; Baisthakur, P.; Yemul, O.S. Synthesis, characterization and application of crosslinked alginate as green packaging material. Heliyon 2020, 6, e03026. [CrossRef] [PubMed]

356. Mahcene, Z.; Khelil, A.; Hasni, S.; Akman, P.K.; Bozkurt, F.; Birech, K.; Goudjil, M.B.; Tornuk, F. Development and characterization of sodium alginate based active edible films incorporated with essential oils of some medicinal plants. Int. J. Biol. Macromol. 2020, 145, 124-132. [CrossRef]

357. Rangel-Marrón, M.; Mani-López, E.; Palou, E.; López-Malo, A. Effects of alginate-glycerol-citric acid concentrations on selected physical, mechanical, and barrier properties of papaya puree-based edible films and coatings, as evaluated by response surface methodology. LWT 2019, 101, 83-91. [CrossRef]

358. Koushki, M.R.; Azizi, M.H.; Azizkhani, M.; Koohy-Kamaly, P. Effect of Different Formulations on Mechanical and Physical Properties of Calcium Alginate Edible Films. J. Food Qual. Hazards Control 2015, 2, 45-50.

359. Elzoghby, A.O.; Abo El-Fotoh, W.S.; Elgindy, N.A. Casein-based formulations as promising controlled release drug delivery systems. J. Control. Release 2011, 153, 206-216. [CrossRef]

360. Jeya, J.; Chandrasekaran, M.; Durairaj, R.; Mageshwaran, G.; Joseph, G.B. A Brief Review on Edible Food Packaging Materials. J. Glob. Eng. Probl. Solut. 2017, 1, 9-19.

361. Khwaldia, K.; Ferez, C.; Banon, S.; Desobry, S.; Hardy, J. Milk proteins for edible films and coatings. Crit. Rev. Food Sci. Nutr. 2004, 44, 239-251. [CrossRef]

362. Shendurse, A.; Gopikrishna, G.; Profile, S.; Pandya, A.J. Milk protein based edible films and coatings-preparation, properties and food applications. J. Nutr. Heal. Food Eng. 2018, 8, 219-226. [CrossRef]

363. Tkaczewska, J. Peptides and protein hydrolysates as food preservatives and bioactive components of edible films and coatings-A review. Trends Food Sci. Technol. 2020, 106, 298-311. [CrossRef]

364. Singh, P.; Singh, T.P.; Gandhi, N. Prevention of lipid oxidation in muscle foods by milk proteins and peptides: A review. Food Rev. Int. 2018, 34, 226-247. [CrossRef]

365. Chambi, H.; Grosso, C. Edible films produced with gelatin and casein cross-linked with transglutaminase. Food Res. Int. 2006, 39, 458-466. [CrossRef]

366. Fabra, M.J.; Talens, P.; Chiralt, A. Influence of calcium on tensile, optical and water vapor permeability properties of sodium caseinate edible films. J. Food Eng. 2010, 96, 356-364. [CrossRef]

367. Mauer, L.J.; Smith, D.E.; Labuza, T.P. Water vapor permeability, mechanical, and structural properties of edible $\beta$-casein films. Int. Dairy J. 2000, 10, 353-358. [CrossRef]

368. Schou, M.; Longares, A.; Montesinos-Herrero, C.; Monahan, F.J.; O'Riordan, D.; O'Sullivan, M. Properties of edible sodium caseinate films and their application as food wrapping. LWT Food Sci. Technol. 2005, 38, 605-610. [CrossRef]

369. Tomasula, P.M.; Parris, N.; Yee, W.; Coffin, D. Properties of Films Made from $\mathrm{CO}_{2}$-Precipitated Casein. J. Agric. Food Chem. 1998, 46, 4470-4474. [CrossRef]

370. Pankaj, S.K.; Bueno-Ferrer, C.; Misra, N.N.; O’Neill, L.; Tiwari, B.K.; Bourke, P.; Cullen, P.J. Physicochemical characterization of plasma-treated sodium caseinate film. Food Res. Int. 2014, 66, 438-444. [CrossRef]

371. Ma, Y.; Teng, A.; Zhao, K.; Zhang, K.; Zhao, H.; Duan, S.; Li, S.; Guo, Y.; Wang, W. A top-down approach to improve collagen film's performance: The comparisons of macro, micro and nano sized fibers. Food Chem. 2020, 309, 125624. [CrossRef]

372. Yamauchi, K.; Takeuchi, N.; Kurimoto, A.; Tanabe, T. Films of collagen crosslinked by S-S bonds: Preparation and characterization. Biomaterials 2001, 22, 855-863. [CrossRef] 
373. Mauri, A.N.; Añón, M.C. Mechanical and Physical Properties of Soy Protein Films with pH-Modified Microstructures. Food Sci. Technol. Int. 2008, 14, 119-125. [CrossRef]

374. Matmaroh, K.; Benjakul, S.; Prodpran, T.; Encarnacion, A.B.; Kishimura, H. Characteristics of acid soluble collagen and pepsin soluble collagen from scale of spotted golden goatfish (Parupeneus heptacanthus). Food Chem. 2011, 129, 1179-1186. [CrossRef]

375. Shi, D.; Liu, F.; Yu, Z.; Chang, B.; Goff, H.D.; Zhong, F. Effect of aging treatment on the physicochemical properties of collagen films. Food Hydrocoll. 2019, 87, 436-447. [CrossRef]

376. Hashim, P.; Mohd Ridzwan, M.S.; Bakar, J.; Mat Hashim, D. Collagen in food and beverage industries. Int. Food Res. J. 2015, 22, $1-8$.

377. Oechsle, A.M.; Wittmann, X.; Gibis, M.; Kohlus, R.; Weiss, J. Collagen entanglement influenced by the addition of acids. Eur. Polym. J. 2014, 58, 144-156. [CrossRef]

378. Hosseini, S.F.; Gómez-Guillén, M.C. A state-of-the-art review on the elaboration of fish gelatin as bioactive packaging: Special emphasis on nanotechnology-based approaches. Trends Food Sci. Technol. 2018, 79, 125-135. [CrossRef]

379. Wolf, K.L.; Sobral, P.J.A.; Telis, V.R.N. Physicochemical characterization of collagen fibers and collagen powder for self-composite film production. Food Hydrocoll. 2009, 23, 1886-1894. [CrossRef]

380. Cheng, S.; Wang, W.; Li, Y.; Gao, G.; Zhang, K.; Zhou, J.; Wu, Z. Cross-linking and film-forming properties of transglutaminasemodified collagen fibers tailored by denaturation temperature. Food Chem. 2019, 271, 527-535. [CrossRef]

381. Gennadios, A.; Hanna, M.A.; Kurth, L.B. Application of edible coatings on meats, poultry and seafoods: A review. LWT Food Sci. Technol. 1997, 30, 337-350. [CrossRef]

382. Ross-Murphy, S.B. Structure and rheology of gelatin gels: Recent progress. Polymer 1992, 33, 2622-2627. [CrossRef]

383. Djabourov, M.; Lechaire, J.P.; Gaill, F. Structure and rheology of gelatin and collagen gels. Biorheology 1993, 30, 191-205. [CrossRef] [PubMed]

384. Deiber, J.A.; Ottone, M.L.; Piaggio, M.V.; Peirotti, M.B. Characterization of cross-linked polyampholytic gelatin hydrogels through the rubber elasticity and thermodynamic swelling theories. Polymer 2009, 50, 6065-6075. [CrossRef]

385. Gómez-Guillén, M.C.; Turnay, J.; Fernández-Díaz, M.D.; Ulmo, N.; Lizarbe, M.A.; Montero, P. Structural and physical properties of gelatin extracted from different marine species: A comparative study. Food Hydrocoll. 2002, 16, 25-34. [CrossRef]

386. Carvalho, R.A.; Sobral, P.J.A.; Thomazine, M.; Habitante, A.M.Q.B.; Giménez, B.; Gómez-Guillén, M.C.; Montero, P. Development of edible films based on differently processed Atlantic halibut (Hippoglossus hippoglossus) skin gelatin. Food Hydrocoll. 2008, 22, 1117-1123. [CrossRef]

387. Mu, C.; Guo, J.; Li, X.; Lin, W.; Li, D. Preparation and properties of dialdehyde carboxymethyl cellulose crosslinked gelatin edible films. Food Hydrocoll. 2012, 27, 22-29. [CrossRef]

388. Ustunol, Z. Edible Films and Coatings for Meat and Poultry. In Edible Films and Coatings for Food Applications, 1st ed.; Huber, K., Embuscado, M., Eds.; Springer: New York, NY, USA, 2009; pp. 245-268. [CrossRef]

389. Andreuccetti, C.; Carvalho, R.A.; Grosso, C.R.F. Effect of hydrophobic plasticizers on functional properties of gelatin-based films. Food Res. Int. 2009, 42, 1113-1121. [CrossRef]

390. Mohamed, S.A.A.; El-Sakhawy, M.; Nashy, E.S.H.A.; Othman, A.M. Novel natural composite films as packaging materials with enhanced properties. Int. J. Biol. Macromol. 2019, 136, 774-784. [CrossRef] [PubMed]

391. Kim, D.; Min, S.C. Trout Skin Gelatin-Based Edible Film Development. J. Food Sci. 2012, 77, E240-E246. [CrossRef]

392. Sompie, M.; Tinangon, R.M.; Surtijono, S.E.; Said, M.I. Effect of long-time immersion in edible film solution from local chicken claw on the physical and chemical properties of chicken meat. IOP Conf. Ser. Earth Environ. Sci. 2020, 492, 012056. [CrossRef]

393. Park, J.; Nam, J.; Yun, H.; Jin, H.J.; Kwak, H.W. Aquatic polymer-based edible films of fish gelatin crosslinked with alginate dialdehyde having enhanced physicochemical properties. Carbohydr. Polym. 2020, 254, 117317. [CrossRef]

394. Sobral, P.J.A.; Menegalli, F.C.; Hubinger, M.D.; Roques, M.A. Mechanical, water vapor barrier and thermal properties of gelatin based edible films. Food Hydrocoll. 2001, 15, 423-432. [CrossRef]

395. Bertan, L.C.; Tanada-Palmu, P.S.; Siani, A.C.; Grosso, C.R.F. Effect of fatty acids and "Brazilian elemi” on composite films based on gelatin. Food Hydrocoll. 2005, 19, 73-82. [CrossRef]

396. Ribba, L.; Garcia, N.L.; D'Accorso, N.; Goyanes, S. Chapter 3Disadvantages of Starch-Based Materials, Feasible Alternatives in Order to Overcome These Limitations. In Starch-Based Materials in Food Packaging, 1st ed.; Villar, M.A., Barbosa, S.E., García, M.A., Castillo, L.A., López, O.V., Eds.; Academic Press: London, UK, 2017; pp. 37-76. [CrossRef]

397. Molavi, H.; Behfar, S.; Shariati, M.A.; Kaviani, M.; Atarod, S. A review on biodegradable starch based film. J. Microbiol. Biotech. Food Sci. 2015, 4, 456-461. [CrossRef]

398. Sánchez-González, L.; Arab-Tehrany, E.; Cháfer, M.; González-Martínez, C.; Chiralt, A. Active Edible and Biodegradable Starch Films. In Polysaccharides, 1st ed.; Ramawat, K.G., Mérillon, J.-M., Eds.; Springer: Cham, Switzerland, 2014; pp. 1-15. [CrossRef]

399. Shah, U.; Naqash, F.; Gani, A.; Masoodi, F.A. Art and Science behind Modified Starch Edible Films and Coatings: A Review. Compr Rev Food Sci Food Saf. 2016, 15, 568-580. [CrossRef]

400. Perez Sira, E.; Dufour, D. Native and Modified Starches as Matrix for Edible Films and Covers. Nutr. Food Sci. Int. J. 2017, 3 , 555615. [CrossRef]

401. Farahnaky, A.; Saberi, B.; Majzoobi, M. Effect of glycerol on physical and mechanical properties of wheat starch edible films. J. Texture Stud. 2013, 44, 176-186. [CrossRef] 
402. Ugalde, M.L.; de Cezaro, A.M.; Vedovatto, F.; Paroul, N.; Steffens, J.; Valduga, E.; Backes, G.T.; Franceschi, E.; Cansian, R.L. Active starch biopolymeric packaging film for sausages embedded with essential oil of Syzygium aromaticum. J. Food Sci. Technol. 2017, 54, 2171-2175. [CrossRef]

403. Sapper, M.; Chiralt, A. Starch-Based Coatings for Preservation of Fruits and Vegetables. Coatings 2018, 8, 152. [CrossRef]

404. Khumkomgool, A.; Saneluksana, T.; Harnkarnsujarit, N. Active meat packaging from thermoplastic cassava starch containing sappan and cinnamon herbal extracts via LLDPE blown-film extrusion. Food Packag. Shelf Life 2020, 26, 100557. [CrossRef]

405. Bhattacharya, D.; Kandeepan, G. Selection of biopolymers to develop a biodegradable and edible film for packaging of luncheon chicken meat slices. Asian J. Dairy Food Res. 2017, 36, 67-71. [CrossRef]

406. Huber, K.; Embuscado, M. Edible Films and Coatings for Food Applications, 1st ed.; Springer: New York, NY, USA, 2009; 411p. [CrossRef]

407. Kalia, S.; Dufresne, A.; Cherian, B.M.; Kaith, B.S.; Averous, L.; Njuguna, J.; Nassiopoulos, E. Cellulose-Based Bio- and Nanocomposites: A Review. Int. J. Polym. Sci. 2011, 2011, 837875. [CrossRef]

408. Shit, S.C.; Shah, P.M. Edible Polymers: Challenges and Opportunities. J. Polym. 2014, 2014, 427259. [CrossRef]

409. Fotie, G.; Limbo, S.; Piergiovanni, L. Manufacturing of Food Packaging Based on Nanocellulose: Current Advances and Challenges. Nanomaterials 2020, 10, 1726. [CrossRef]

410. Tajeddin, B. Chapter 21. Cellulose-Based Polymers for Packaging Applications. In Lignocellulosic Polymer Composites, 1st ed.; Thakur, V.K., Ed.; Scrivener Publishing LLC: Beverly, MA, USA, 2014; pp. 477-498. [CrossRef]

411. Silva, F.A.G.S.; Dourado, F.; Gama, M.; Poças, F. Nanocellulose Bio-Based Composites for Food Packaging. Nanomaterials 2020, 10, 2041. [CrossRef] [PubMed]

412. Ghosh, T.; Katiyar, V. Cellulose-Based Hydrogel Films for Food Packaging. In Cellulose-Based Superabsorbent Hydrogels. Polymers and Polymeric Composites: A Reference Series, 1st ed.; Mondal, M., Ed.; Springer: Cham, Switzerland, 2019; pp. 1061-1084. [CrossRef]

413. Zhao, Y.; Sun, H.; Yang, B.; Weng, Y. Hemicellulose-Based Film: Potential Green Films for Food Packaging. Polymers 2020, 12, 1775. [CrossRef]

414. Sirviö, J.A.; Visanko, M.; Ukkola, J.; Liimatainen, H. Effect of plasticizers on the mechanical and thermomechanical properties of cellulose-based biocomposite films. Ind. Crops Prod. 2018, 122, 513-521. [CrossRef]

415. Vieira, M.G.A.; da Silva, M.A.; dos Santos, L.O.; Beppu, M.M. Natural-based plasticizers and biopolymer films: A review. Eur. Polym. J. 2011, 47, 254-263. [CrossRef]

416. Khan, A.; Niazi, M.B.K.; Naqvi, S.R.; Farooq, W. Influence of Plasticizers on Mechanical and Thermal Properties of Methyl Cellulose-Based Edible Films. J. Polym. Environ. 2018, 26, 291-300. [CrossRef]

417. Indrarti, L.; Indriyati; Syampurwadi, A.; Pujiastuti, S. Physical and Mechanical Properties of Modified Bacterial Cellulose Composite Films. AIP Conf. Proc. 2016, 1711, 050007. [CrossRef]

418. Mellinas, C.; Ramos, M.; Jiménez, A.; Garrigós, M.C. Recent Trends in the Use of Pectin from Agro-Waste Residues as a Natural-Based Biopolymer for Food Packaging Applications. Materials 2020, 13, 673. [CrossRef] [PubMed]

419. Kumar, S.; Mukherjee, A.; Dutta, J. Chitosan based nanocomposite films and coatings: Emerging antimicrobial food packaging alternatives. Trends Food Sci. Technol. 2020, 97, 196-209. [CrossRef]

420. Bourbon, A.I.; Pinheiro, A.C.; Cerqueira, M.A.; Rocha, C.M.R.; Avides, M.C.; Quintas, M.A.C.; Vicente, A.A. Physico-chemical characterization of chitosan-based edible films incorporating bioactive compounds of different molecular weight. J. Food Eng. 2011, 106, 111-118. [CrossRef]

421. Souza, V.G.L.; Pires, J.R.A.; Rodrigues, C.; Coelhoso, I.M.; Fernando, A.L. Chitosan Composites in Packaging Industry—Current Trends and Future Challenges. Polymers 2020, 12, 417. [CrossRef]

422. Haghighi, H.; Licciardello, F.; Fava, P.; Siesler, H.W.; Pulvirenti, A. Recent advances on chitosan-based films for sustainable food packaging applications. Food Packag. Shelf Life 2020, 26, 100551. [CrossRef]

423. Morin-Crini, N.; Lichtfouse, E.; Torri, G.; Crini, G. Fundamentals and Applications of Chitosan. In Sustainable Agriculture Reviezws 35. Sustainable Agriculture Reviews., 1st ed.; Crini, G., Lichtfouse, E., Eds.; Springer: Cham, Switzerland, 2019; Volume 35, pp. 49-123. [CrossRef]

424. Cissé, M.; Montet, D.; Loiseau, G.; Ducamp-Collin, M.-N. Influence of the Concentrations of Chitosan and Glycerol on Edible Film Properties Showed by Response Surface Methodology. J. Polym. Environ. 2012, 20, 830-837. [CrossRef]

425. Singh, T.P.; Chatli, M.K.; Sahoo, J. Development of chitosan based edible films: Process optimization using response surface methodology. J. Food Sci. Technol. 2015, 52, 2530-2543. [CrossRef]

426. Wang, H.; Qian, J.; Ding, F. Emerging Chitosan-Based Films for Food Packaging Applications. J. Agric. Food Chem. 2018, 66, 395-413. [CrossRef]

427. Abdullah, N.A.S.; Mohamad, Z.; Khan, Z.I.; Jusoh, M.; Zakaria, Z.Y.; Ngadi, N. Alginate Based Sustainable Films and Composites for Packaging: A Review. Chem. Eng. Trans. 2021, 83, 271-276. [CrossRef]

428. Marismandani, A.D.P.; Husni, A. Development and Characterization of Biobased Alginate/Glycerol/Virgin Coconut Oil as Biodegradable Packaging. E3S Web Conf. 2020, 147, 03016. [CrossRef]

429. Nehchiri, N.; Amiri, S.; Radi, M. Improving the water barrier properties of alginate packaging films by submicron coating with drying linseed oil. Packag. Technol. Sci. 2021, 34, 283-295. [CrossRef]

430. Gheorghita, R.; Gutt, G.; Amariei, S. The Use of Edible Films Based on Sodium Alginate in Meat Product Packaging: An Eco-Friendly Alternative to Conventional Plastic Materials. Coatings 2020, 10, 166. [CrossRef] 
431. Nataraj, D.; Reddy, N. Chemical modifications of alginate and its derivatives. Int. J. Chem. Res. 2020, 4, 1-17. [CrossRef]

432. Yang, J.-S.; Xie, Y.-J.; He, W. Research progress on chemical modification of alginate: A review. Carbohydr. Polym. 2011, 84, 33-39. [CrossRef]

433. Lee, K.Y.; Mooney, D.J. Alginate: Properties and biomedical applications. Prog. Polym. Sci. 2012, 37, 106-126. [CrossRef] [PubMed]

434. Bourtoom, T. Edible protein films: Properties enhancement. Int. Food Res. J. 2009, 16, 1-9.

435. Wagh, Y.R.; Pushpadass, H.A.; Emerald, F.M.; Nath, B.S. Preparation and characterization of milk protein films and their application for packaging of Cheddar cheese. J. Food Sci. Technol. 2014, 51, 3767-3775. [CrossRef]

436. Khwaldia, K.; Banon, S.; Perez, C.; Desobry, S. Properties of Sodium Caseinate Film-Forming Dispersions and Films. J. Dairy Sci. 2004, 87, 2011-2016. [CrossRef]

437. Abdalrazeq, M.; Giosafatto, C.V.L.; Esposito, M.; Fenderico, M.; Di Pierro, P.; Porta, R. Glycerol-Plasticized Films Obtained from Whey Proteins Denatured at Alkaline pH. Coatings 2019, 9, 322. [CrossRef]

438. Arrieta, M.P.; Peltzer, M.A.; del Carmen Garrigós, M.; Jiménez, A. Structure and mechanical properties of sodium and calcium caseinate edible active films with carvacrol. J. Food Eng. 2013, 114, 486-494. [CrossRef]

439. Maruddin, F.; Malaka, R.; Baba, S.; Amqam, H.; Taufik, M.; Sabil, S. Brightness, elongation and thickness of edible film with caseinate sodium using a type of plasticizer. IOP Conf. Ser. Earth Environ. Sci. 2020, 492, 012043. [CrossRef]

440. Saez-Orviz, S.; Laca, A.; Rendueles, M.; Díaz, M. Approaches for casein film uses in food stuff packaging. Afinidad-Barcelona 2017, 74, 26-29.

441. Coltelli, M.B.; Wild, F.; Bugnicourt, E.; Cinelli, P.; Lindner, M.; Schmid, M.; Weckel, V.; Müller, K.; Rodriguez, P.; Staebler, A.; et al. State of the art in the development and properties of protein-based films and coatings and their applicability to cellulose based products: An extensive review. Coatings 2016, 6, 1. [CrossRef]

442. Said, M.I.; Erwanto, Y.; Abustam, E. Properties of Edible Film Produced using Combination of Collagen Extracts of Bligon Goatskin with Glycerol. Am. J. Anim. Vet. Sci. 2016, 11, 151-159. [CrossRef]

443. Alizadeh, A.; Behfar, S. Properties of collagen based edible films in food packaging: A review. Ann. Biol. Res. $2013,4,253-256$.

444. Mihalca, V.; Kerezsi, A.D.; Weber, A.; Gruber-Traub, C.; Schmucker, J.; Vodnar, D.C.; Dulf, F.V.; Socaci, S.A.; Fărcaș, A.; Mureșan, C.I.; et al. Protein-Based Films and Coatings for Food Industry Applications. Polymers 2021, 13, 769. [CrossRef] [PubMed]

445. Chen, C.; Liu, F.; Yu, Z.; Ma, Y.; Goff, H.D.; Zhong, F. Improvement in physicochemical properties of collagen casings by glutaraldehyde cross-linking and drying temperature regulating. Food Chem. 2020, 318, 126404. [CrossRef]

446. Ikeuchi, Y. 24 - Recent advances in the application of high pressure technology to processed meat products. In Woodhead Publishing Series in Food Science, Technology and Nutrition, Processed Meats, 1st ed.; Kerry, J.P., Kerry, J.F., Eds.; Woodhead Publishing: Cambridge, UK, 2011; pp. 590-616. [CrossRef]

447. Wu, X.; Liu, Y.; Wang, W.; Han, Y.; Liu, A. Improved mechanical and thermal properties of gelatin films using a nano inorganic filler. J. Food Process Eng. 2017, 40, e12469. [CrossRef]

448. Wihodo, M.; Moraru, C.I. Physical and chemical methods used to enhance the structure and mechanical properties of protein films: A review. J. Food Eng. 2013, 114, 292-302. [CrossRef]

449. Etxabide, A.; Uranga, J.; Guerrero, P.; de la Caba, K. Improvement of barrier properties of fish gelatin films promoted by gelatin glycation with lactose at high temperatures. LWT Food Sci. Technol. 2015, 63, 315-321. [CrossRef]

450. Thomazine, M.; Carvalho, R.A.; Sobral, P.J.A. Physical Properties of Gelatin Films Plasticized by Blends of Glycerol and Sorbitol. J. Food Sci. 2005, 70, E172-E176. [CrossRef]

451. Arpi, N.; Fahrizal; Martunis; Hardianti, E. Preparation and characterization of biodegradable film based on skin and bone fish gelatin. IOP Conf. Ser. Earth Environ. Sci. 2018, 207, 012050. [CrossRef]

452. Al-Hassan, A.A.; Norziah, M.H. Starch-gelatin edible films: Water vapor permeability and mechanical properties as affected by plasticizers. Food Hydrocoll. 2012, 26, 108-117. [CrossRef]

453. Thi, M.T.L.; Hiroki, M.; Emiko, O.; Kazufumi, O. Effect of preparing conditions on properties of gelatin film from horse mackerel scale. KnE Life Sci. 2015, 32-34. [CrossRef]

454. Jorge, M.F.C.; Alexandre, E.M.C.; Flaker, C.H.C.; Bittante, A.M.Q.B.; Sobral, P.J.d.A. Biodegradable Films Based on Gelatin and Montmorillonite Produced by Spreading. Int. J. Polym. Sci. 2015, 2015, 806791. [CrossRef]

455. Azmi, N.S.; Basha, R.K.; Arifin, N.N.T.; Othman, S.H.; Mohammed, M.A.P. Functional Properties of Tilapia's Fish Scale Gelatin Film: Effects of Different Type of Plasticizers. Sains Malays. 2020, 49, 2221-2229. [CrossRef]

456. Bonilla, J.; Atarés, L.; Vargas, M.; Chiralt, A. Edible films and coatings to prevent the detrimental effect of oxygen on food quality: Possibilities and limitations. J. Food Eng. 2012, 110, 208-213. [CrossRef]

457. Zhang, X.; Zhao, Y.; Li, Y.; Zhu, L.; Fang, Z.; Shi, Q. Physicochemical, mechanical and structural properties of composite edible films based on whey protein isolate/psyllium seed gum. Int. J. Biol. Macromol. 2020, 153, 892-901. [CrossRef] [PubMed]

458. Pérez-Vergara, L.D.; Cifuentes, M.T.; Franco, A.P.; Pérez-Cervera, C.E.; Andrade-Pizarro, R.D. Development and characterization of edible films based on native cassava starch, beeswax, and propolis. NFS J. 2020, 21, 39-49. [CrossRef]

459. Suwanprateep, S.; Kumsapaya, C.; Sayan, P. Structure and Thermal Properties of Rice Starch-based Film Blended with Mesocarp Cellulose Fiber. Mater. Today 2019, 17, 2039-2047. [CrossRef]

460. Dias, A.B.; Müller, C.M.O.; Larotonda, F.D.S.; Laurindo, J.B. Mechanical and barrier properties of composite films based on rice flour and cellulose fibers. LWT Food Sci. Technol. 2011, 44, 535-542. [CrossRef] 
461. Ma, X.; Chang, P.R.; Yu, J. Properties of biodegradable thermoplastic pea starch/carboxymethyl cellulose and pea starch/microcrystalline cellulose composites. Carbohydr. Polym. 2008, 72, 369-375. [CrossRef]

462. Tosati, J.V.; Messias, V.C.; Carvalho, P.I.N.; Rodrigues Pollonio, M.A.; Meireles, M.A.A.; Monteiro, A.R. Antimicrobial Effect of Edible Coating Blend Based on Turmeric Starch Residue and Gelatin Applied onto Fresh Frankfurter Sausage. Food Bioprocess Technol. 2017, 10, 2165-2175. [CrossRef]

463. Sirviö, J.A.; Kolehmainen, A.; Liimatainen, H.; Niinimäki, J.; Hormi, O.E.O. Biocomposite cellulose-alginate films: Promising packaging materials. Food Chem. 2014, 151, 343-351. [CrossRef] [PubMed]

464. Pei, Y.; Yang, J.; Liu, P.; Xu, M.; Zhang, X.; Zhang, L. Fabrication, properties and bioapplications of cellulose/collagen hydrolysate composite films. Carbohydr. Polym. 2013, 92, 1752-1760. [CrossRef] [PubMed]

465. Wu, Y.; Luo, X.; Li, W.; Song, R.; Li, J.; Li, Y.; Li, B.; Liu, S. Green and biodegradable composite films with novel antimicrobial performance based on cellulose. Food Chem. 2016, 197, 250-256. [CrossRef] [PubMed]

466. Brito, T.B.; Carrajola, J.F.; Gonçalves, E.C.B.A.; Martelli-Tosi, M.; Ferreira, M.S.L. Fruit and vegetable residues flours with different granulometry range as raw material for pectin-enriched biodegradable film preparation. Food Res. Int. 2019, 121, 412-421. [CrossRef]

467. Nešić, A.; Onjia, A.; Davidović, S.; Dimitrijević, S.; Errico, M.E.; Santagata, G.; Malinconico, M. Design of pectin-sodium alginate based films for potential healthcare application: Study of chemico-physical interactions between the components of films and assessment of their antimicrobial activity. Carbohydr. Polym. 2017, 157, 981-990. [CrossRef]

468. Giosafatto, C.V.L.; Di Pierro, P.; Gunning, P.; Mackie, A.; Porta, R.; Mariniello, L. Characterization of Citrus pectin edible films containing transglutaminase-modified phaseolin. Carbohydr. Polym. 2014, 106, 200-208. [CrossRef]

469. Ahmad, M.; Nirmal, N.P.; Danish, M.; Chuprom, J.; Jafarzedeh, S. Characterisation of composite films fabricated from collagen/chitosan and collagen/soy protein isolate for food packaging applications. RSC Adv. 2016, 6, 82191-82204. [CrossRef]

470. Hu, D.; Wang, H.; Wang, L. Physical properties and antibacterial activity of quaternized chitosan/carboxymethyl cellulose blend films. LWT Food Sci. Technol. 2016, 65, 398-405. [CrossRef]

471. Galus, S.; Lenart, A. Development and characterization of composite edible films based on sodium alginate and pectin. J. Food Eng. 2013, 115, 459-465. [CrossRef]

472. Nkenmogne Kamdem, I.E.; Saidou, C.; Ngassoum, M.B.; Ndjouenkeu, R. Synergistic interactions in dilute aqueous solutions between alginate and tropical vegetal hydrocolloids. Heliyon 2020, 6, e04348. [CrossRef]

473. De Oliveira Filho, J.G.; Rodrigues, J.M.; Valadares, A.C.F.; de Almeida, A.B.; de Lima, T.M.; Takeuchi, K.P.; Alves, C.C.F.; de Figueiredo Sousa, H.A.; da Silva, E.R.; Dyszy, F.H.; et al. Active food packaging: Alginate films with cottonseed protein hydrolysates. Food Hydrocoll. 2019, 92, 267-275. [CrossRef]

474. Gomaa, M.; Hifney, A.F.; Fawzy, M.A.; Abdel-Gawad, K.M. Use of seaweed and filamentous fungus derived polysaccharides in the development of alginate-chitosan edible films containing fucoidan: Study of moisture sorption, polyphenol release and antioxidant properties. Food Hydrocoll. 2018, 82, 239-247. [CrossRef]

475. Chick, J.; Hernandez, R.J. Physical, Thermal, and Barrier Characterization of Casein-Wax-Based Edible Films. J. Food Sci. 2002, 67, 1073-1079. [CrossRef]

476. Yao, Y.; Wang, H.; Wang, R.; Chai, Y. Preparation and characterization of homogeneous and enhanced casein protein-based composite films via incorporating cellulose microgel. Sci. Rep. 2019, 9, 1-11. [CrossRef]

477. Eghbal, N.; Degraeve, P.; Oulahal, N.; Yarmand, M.S.; Mousavi, M.E.; Gharsallaoui, A. Low methoxyl pectin/sodium caseinate interactions and composite film formation at neutral pH. Food Hydrocoll. 2017, 69, 132-140. [CrossRef]

478. Ben Slimane, E.; Sadok, S. Collagen from Cartilaginous Fish By-Products for a Potential Application in Bioactive Film Composite. Mar. Drugs 2018, 16, 211. [CrossRef]

479. Ding, C.; Zhang, M.; Li, G. Preparation and characterization of collagen/hydroxypropyl methylcellulose (HPMC) blend film. Carbohydr. Polym. 2015, 119, 194-201. [CrossRef] [PubMed]

480. Lima, Á.M.; Cerqueira, M.A.; Souza, B.W.S.; Santos, E.C.M.; Teixeira, J.A.; Moreira, R.A.; Vicente, A.A. New edible coatings composed of galactomannans and collagen blends to improve the postharvest quality of fruits-Influence on fruits gas transfer rate. J. Food Eng. 2010, 97, 101-109. [CrossRef]

481. Bonilla, J.; Sobral, P.J.A. Gelatin-chitosan edible film activated with Boldo extract for improving microbiological and antioxidant stability of sliced Prato cheese. Int. J. Food Sci. Technol. 2019, 54, 1617-1624. [CrossRef]

482. Jridi, M.; Hajji, S.; Ben Ayed, H.; Lassoued, I.; Mbarek, A.; Kammoun, M.; Souissi, N.; Nasri, M. Physical, structural, antioxidant and antimicrobial properties of gelatin-chitosan composite edible films. Int. J. Biol. Macromol. 2014, 67, 373-379. [CrossRef]

483. Cao, N.; Fu, Y.; He, J. Preparation and physical properties of soy protein isolate and gelatin composite films. Food Hydrocoll. 2007, 21, 1153-1162. [CrossRef]

484. Wang, L.; Auty, M.A.E.; Kerry, J.P. Physical assessment of composite biodegradable films manufactured using whey protein isolate, gelatin and sodium alginate. J. Food Eng. 2010, 96, 199-207. [CrossRef]

485. Tabari, M. Investigation of Carboxymethyl Cellulose (CMC) on Mechanical Properties of Cold Water Fish Gelatin Biodegradable Edible Films. Foods 2017, 6, 41. [CrossRef]

486. Kurek, M.; Galus, S.; Debeaufort, F. Surface, mechanical and barrier properties of bio-based composite films based on chitosan and whey protein. Food Packag. Shelf Life 2014, 1, 56-67. [CrossRef] 
487. Nair, M.S.; Tomar, M.; Punia, S.; Kukula-Koch, W.; Kumar, M. Enhancing the functionality of chitosan- and alginate-based active edible coatings/films for the preservation of fruits and vegetables: A review. Int. J. Biol. Macromol. 2020, 164, 304-320. [CrossRef]

488. Valdés, A.; Mellinas, A.C.; Ramos, M.; Garrigós, M.C.; Jiménez, A. Natural additives and agricultural wastes in biopolymer formulations for food packaging. Front. Chem. 2014, 2, 6. [CrossRef]

489. Nor, S.M.; Ding, P. Trends and advances in edible biopolymer coating for tropical fruit: A review. Food Res. Int. 2020, 134, 109208. [CrossRef] [PubMed]

490. Song, Y.; Zheng, Q. Ecomaterials based on food proteins and polysaccharides. Polym. Rev. 2014, 54, 514-571. [CrossRef]

491. Dainelli, D.; Gontard, N.; Spyropoulos, D.; Zondervan-van den Beuken, E.; Tobback, P. Active and intelligent food packaging: Legal aspects and safety concerns. Trends Food Sci. Technol. 2008, 19, S103-S112. [CrossRef]

492. Salgado, P.R.; Ortiz, C.M.; Musso, Y.S.; Di Giorgio, L.; Mauri, A.N. Edible films and coatings containing bioactives. Curr. Opin. Food Sci. 2015, 5, 86-92. [CrossRef]

493. Cuq, B.; Gontard, N.; Guilbert, S. Edible films and coatings as active layers. In Active Food Packaging, 1st ed.; Rooney, M.L., Ed.; Springer: Boston, MA, USA, 1995; pp. 111-142. [CrossRef]

494. Suput, D.; Lazic, V.; Popovic, S.; Hromis, N. Edible films and coatings: Sources, properties and application. Food Feed Res. 2015, 42, 11-22. [CrossRef]

495. ASTM D882-10 Standard Test Method for Tensile Properties of Thin Plastic Sheeting. 2010. Available online: https://doi.org/10.1 520/D0882-10 (accessed on 24 December 2020).

496. Acevedo-Fani, A.; Salvia-Trujillo, L.; Rojas-Graü, M.A.; Martín-Belloso, O. Edible films from essential-oil-loaded nanoemulsions: Physicochemical characterization and antimicrobial properties. Food Hydrocoll. 2015, 47, 168-177. [CrossRef]

497. Han, J.H.; Aristippos, G. 15 - Edible films and coatings: A review. In Innovations in Food Packaging, 1st ed.; Han, J.H., Ed.; Academic Press: Cambridge, MA, USA, 2005; pp. 239-262. [CrossRef]

498. Lacroix, M. Mechanical and Permeability Properties of Edible Films and Coatings for Food and Pharmaceutical Applications. In Edible Films and Coatings for Food Applications, 1st ed.; Huber, K., Embuscado, M., Eds.; Springer: New York, NY, USA, 2009; pp. 347-366. [CrossRef]

499. Avramescu, S.M.; Butean, C.; Popa, C.V.; Ortan, A.; Moraru, I.; Temocico, G. Edible and Functionalized Films/CoatingsPerformances and Perspectives. Coatings 2020, 10, 687. [CrossRef]

500. ISO 527-1:2019(en), Plastics—Determination of Tensile Properties—Part 1: General Principles. 2019. Available online: https: //www.iso.org/ru/standard/75824.html (accessed on 24 December 2020).

501. McHugh, T.H.; Krochta, J.M. Sorbitol-vs Glycerol-Plasticized Whey Protein Edible Films: Integrated Oxygen Permeability and Tensile Property Evaluation. J. Agric. Food Chem. 1994, 42, 841-845. [CrossRef]

502. Nandane, A.S.; Jain, R. Study of mechanical properties of soy protein based edible film as affected by its composition and process parameters by using RSM. J. Food Sci. Technol. 2015, 52, 3645-3650. [CrossRef]

503. Pena-Serna, C.; Lopes Filho, J.F. Biodegradable zein-based blend films: Structural, mechanical and barrier properties. Food Technol. Biotechnol. 2015, 53, 348-353. [CrossRef]

504. Seung, Y.C.; Rhee, C. Mechanical properties and water vapor permeability of edible films made from fractionated soy proteins with ultrafiltration. LWT Food Sci. Technol. 2004, 37, 833-839. [CrossRef]

505. Arham, R.; Mulyati, M.T.; Metusalach, M.; Salengke, S. Physical and mechanical properties of agar based edible film with glycerol plasticizer. Int. Food Res. J. 2016, 23, 1669-1675. [CrossRef]

506. Choi, W.S.; Han, J.H. Physical and mechanical properties of pea-protein-based edible films. J. Food Sci. 2001, 66, 319-322. [CrossRef]

507. Razmjoo, F.; Sadeghi, E.; Rouhi, M.; Mohammadi, R.; Noroozi, R.; Safajoo, S. Polyvinyl alcohol—Zedo gum edible film: Physical, mechanical and thermal properties. J. Appl. Polym. Sci. 2021, 138, 49875. [CrossRef]

508. Talja, R.A.; Helén, H.; Roos, Y.H.; Jouppila, K. Effect of type and content of binary polyol mixtures on physical and mechanical properties of starch-based edible films. Carbohydr. Polym. 2008, 71, 269-276. [CrossRef]

509. Chillo, S.; Flores, S.; Mastromatteo, M.; Conte, A.; Gerschenson, L.; Del Nobile, M.A. Influence of glycerol and chitosan on tapioca starch-based edible film properties. J. Food Eng. 2008, 88, 159-168. [CrossRef]

510. ASTM D6241 - 14 Standard Test Method for Static Puncture Strength of Geotextiles and Geotextile-Related Products Using a 50-mm Probe. 2014. Available online: https:/ / doi.org/10.1520/D6241-14 (accessed on 25 March 2021).

511. Nur Hazirah, M.A.S.P.; Isa, M.I.N.; Sarbon, N.M. Effect of xanthan gum on the physical and mechanical properties of gelatincarboxymethyl cellulose film blends. Food Packag. Shelf Life 2016, 9, 55-63. [CrossRef]

512. Xiao, B.; Zhang, Y.; Wang, Y.; Jiang, G.; Liang, M.; Chen, X.; Long, G. A Fractal Model for Kozeny-Carman Constant and Dimensionless Permeability of Fibrous Porous Media with Roughened Surfaces. Fractals 2019, 27, 1950116. [CrossRef]

513. Liang, M.; Liu, Y.; Xiao, B.; Yang, S.; Wang, Z.; Han, H. An analytical model for the transverse permeability of gas diffusion layer with electrical double layer effects in proton exchange membrane fuel cells. Int. J. Hydrogen Energy 2018, 43, 17880-17888. [CrossRef]

514. ASTM E96 - 00 Standard Test Methods for Water Vapor Transmission of Materials. 2000. Available online: https://doi.org/10.152 0/E0096-00 (accessed on 25 December 2020).

515. ASTM D3985 - 17 Standard Test Method for Oxygen Gas Transmission Rate Through Plastic Film and Sheeting Using a Coulometric Sensor. 2017. Available online: https:/ / doi.org/10.1520/D3985-17 (accessed on 25 December 2020). 
516. Sanchez-Tamayo, M.I.; Pasos, C.V.; Ochoa-Martinez, C.I. Methods for gas permeability measurement in edible films for fruits and vegetables: A review. Food Sci. Technol. 2020, in press. [CrossRef]

517. Lee, K.T. Quality and safety aspects of meat products as affected by various physical manipulations of packaging materials. Meat Sci. 2010, 86, 138-150. [CrossRef] [PubMed]

518. Butler, B.L.; Vergano, P.J.; Testin, R.F.; Bunn, J.M.; Wiles, J.L. Mechanical and barrier properties of edible chitosan films as affected by composition and storage. J. Food Sci. 1996, 61, 953-956. [CrossRef]

519. Wongphan, P.; Harnkarnsujarit, N. Edible packaging from hydroxypropyl thermoplastic cassava starch, agar and maltodextrin blends produced by cast extrusion. Int. J. Food Sci. Technol. 2020, 56, 62-772. [CrossRef]

520. Sadeghi-Varkani, A.; Emam-Djomeh, Z.; Askari, G. Physicochemical and microstructural properties of a novel edible film synthesized from Balangu seed mucilage. Int. J. Biol. Macromol. 2018, 108, 1110-1119. [CrossRef]

521. Nur Hanani, Z.A.; Roos, Y.H.; Kerry, J.P. Use of beef, pork and fish gelatin sources in the manufacture of films and assessment of their composition and mechanical properties. Food Hydrocoll. 2012, 29, 144-151. [CrossRef]

522. Wang, L.Z.; Liu, L.; Holmes, J.; Kerry, J.F.; Kerry, J.P. Assessment of film-forming potential and properties of protein and polysaccharide-based biopolymer films. Int. J. Food Sci. Technol. 2007, 42, 1128-1138. [CrossRef]

523. Gontard, N.; Guilbert, S. Bio-packaging: Technology and properties of edible and/or biodegradable material of agricultural origin. In Food Packaging and Preservation, 1st ed.; Mathlouthi, M., Ed.; Springer: Boston, MA, USA, 1994; pp. 159-181. [CrossRef]

524. Gontard, N.; Guilbert, S.; Cuq, J.-L. Edible Wheat Gluten Films: Influence of the Main Process Variables on Film Properties using Response Surface Methodology. J. Food Sci. 1992, 57, 190-195. [CrossRef]

525. Da Rosa Zavareze, E.; Storck, C.R.; de Castro, L.A.S.; Schirmer, M.A.; Dias, A.R.G. Effect of heat-moisture treatment on rice starch of varying amylose content. Food Chem. 2010, 121, 358-365. [CrossRef]

526. Kwok, D.Y.; Neumann, A.W. Contact angle measurement and contact angle interpretation. Adv. Colloid Interface Sci. 1999, 81, 167-249. [CrossRef]

527. Walczak, M.; Michalska-Sionkowska, M.; Kaczmarek, B.; Sionkowska, A. Surface and antibacterial properties of thin films based on collagen and thymol. Mater. Today Commun. 2020, 22, 100949. [CrossRef]

528. Gutiérrez, T.J. Surface and nutraceutical properties of edible films made from starchy sources with and without added blackberry pulp. Carbohydr. Polym. 2017, 165, 169-179. [CrossRef] [PubMed]

529. Kwok, D.Y.; Neumann, A.W. Contact angle interpretation in terms of solid surface tension. Colloids Surfaces A Physicochem. Eng. Asp. 2000, 161, 31-48. [CrossRef]

530. Hosseini, S.F.; Rezaei, M.; Zandi, M.; Farahmandghavi, F. Bio-based composite edible films containing Origanum vulgare L. essential oil. Ind. Crops Prod. 2015, 67, 403-413. [CrossRef]

531. De Moura, M.R.; Aouada, F.A.; Avena-Bustillos, R.J.; McHugh, T.H.; Krochta, J.M.; Mattoso, L.H.C. Improved barrier and mechanical properties of novel hydroxypropyl methylcellulose edible films with chitosan/tripolyphosphate nanoparticles. $J$. Food Eng. 2009, 92, 448-453. [CrossRef] 